Portland State University

PDXScholar

Summer 8-28-2018

\title{
Delphinids on Display: the Capture, Care, and Exhibition of Cetaceans at Marineland of the Pacific, 1954-1967
}

Taylor Michael Bailey

Portland State University

Follow this and additional works at: https://pdxscholar.library.pdx.edu/open_access_etds

Part of the History Commons, and the Zoology Commons Let us know how access to this document benefits you.

Recommended Citation

Bailey, Taylor Michael, "Delphinids on Display: the Capture, Care, and Exhibition of Cetaceans at Marineland of the Pacific, 1954-1967" (2018). Dissertations and Theses. Paper 4549.

https://doi.org/10.15760/etd.6434

This Thesis is brought to you for free and open access. It has been accepted for inclusion in Dissertations and Theses by an authorized administrator of PDXScholar. Please contact us if we can make this document more accessible: pdxscholar@pdx.edu. 
Delphinids on Display:

The Capture, Care, and Exhibition of Cetaceans at Marineland of the Pacific, 1954-1967

by

Taylor Michael Bailey

A thesis submitted in partial fulfillment of the requirements for the degree of

\author{
Master of Arts \\ in \\ History \\ Thesis Committee: \\ Catherine McNeur, Chair \\ David A. Johnson \\ Katrine Barber \\ Anita Guerrini
}

Portland State University 2018 
(C) 2018 Taylor Michael Bailey 


\begin{abstract}
$\underline{\text { Abstract }}$
When Marineland of the Pacific opened in 1954 on the Palos Verdes Peninsula in greater Los Angeles, it was the second oceanarium in the world and the first on the West Coast. An initial investment of $\$ 3$ million by Oceanarium Inc., owners of the popular Marine Studios park located near St. Augustine, Florida, ensured that Marineland was built with the same state of the art facilities needed to produce an authentic representation of the ocean floor on land. Building on Marine Studios' success exhibiting bottlenose dolphins (Tursiops truncatus), Marineland's central draw was its performing cetaceans. During the park's early years, its collectors pioneered the capture of Pacific dolphin species, such as the Common dolphin (Delphinus delphis) and the Pacific white-sided dolphin (Lagenorhynchus obliquidens), the short-finned pilot whale (Globicephala macrorhynchus), and were the first to capture a live killer whale (Orcinus orca) in 1961. By exposing audiences to previously unknown species through circus-like performances, Marineland played a central role in changing public perceptions of small cetaceans in the post-World War II era. However, with few prior studies to consult, Marineland curators experimented with their own methods of capture, husbandry, and veterinary care that often resulted in the harm or death of cetaceans under their care. Caretakers contended with animal aggression and sexual behavior, the refusal of animals to perform in show routines, and high mortality. Despite the difficulties posed by exhibiting cetaceans, advertisements, press interviews, and films advanced a contrary narrative that animals under Marineland's care enjoyed the conditions of captivity and performing for an
\end{abstract}


audience. This thesis explores the tension between entertainment and animal care that defined the early years of cetacean captivity in North America. 


\section{Dedication}

For Nan,

whose backyard garden I explored as a child cultivated my fascination with the natural world. 


\section{Acknowledgements}

"Delphinids on Display" is the culmination of nearly three years of research, writing, and editing, and would not have been possible without the support and guidance of many individuals and institutions. Firstly, I am greatly indebted to my parents, Michael and Maria Bailey, as their financial support saw that I made it through my master's program on time. While they may not have initially understood what an "environmental historian" was, or what obtaining a job in academia involved, their steady confidence in me was crucial to the success of this project. My brother Cohen Bailey read and critiqued many versions of this project, and I drew many important conclusions from our lively discussions. During the final months of work on this thesis, my Aunt Dianne and Uncle Sam happily found work for me on their property in Kentucky after I moved back home to Cincinnati, Ohio. Working odd jobs on their farm allowed me to pay my bills at a time when my research and writing schedule made finding a part time job difficult. I am also grateful for the kindness of my dear friend Jonathan Hill, who allowed me to live with him in Connecticut for a short time when I desperately needed a change of scenery (namely, to see the ocean!).

When I began the M.A. in History program at Portland State, my primary advisor Catherine McNeur quickly became an indispensable asset to both my intellectual growth and the development of this project. Her guidance proved crucial as I started navigating the world of environmental history, attending my first academic conferences, and applying to doctoral programs. I learned much of what I know about how to conduct myself as a professional historian from following her example. My secondary field 
advisor, Katy Barber, taught the first course I took at PSU (HST 500), which provided me with an introduction to the field of history. Katy's insightful suggestions nurtured the first seeds of this project when I wrote a sample thesis proposal, and throughout the writing process her astute feedback helped me to add depth and clarity to my arguments. Finally, Professor David Johnson's wisdom and encouragement aided this thesis at many critical points. His vast knowledge of U.S. history and experience growing up in Southern California (as a child he visited Marineland and saw Bubbles perform) helped me to visualize my project as not only a history of science and medicine, but as an investigation of human perceptions. Working as a research assistant on his current book project taught me valuable research skills in data collection and organization, and as a mentor, Dr. Johnson imparted invaluable advice about graduate school, the research process, teaching, and the responsibility of producing quality scholarship.

Although the M.A. program is small, the History Department at PSU provided me with the financial support that made this project possible. Chair Tim Garrison always found pathways to funding that allowed me to travel to archives, conferences, or writing workshops. I greatly benefitted from serving as the Caroline P. Stoel Editorial Fellow for the Pacific Historical Review, which is located at PSU. My time at the PHR bolstered my writing and editing skills, familiarized me with the peer review process, and allowed me to see the production of historical scholarship in action, along with tuition remission and a stipend. Editors Marc Rodriguez and Brenda Frink both supported my professional development and gave a chapter of this thesis critical feedback for a presentation I gave at the Pacific Coast Branch of the American Historical Association's annual conference. History Department staff members Andrea Janda and Jeff Brown made many of the 
logistical aspects of the program much easier to navigate, and when I needed a break from research or class work, they provided thoughtful conversation and advice. Additionally, I established a connection with PSU's Biology Department, where I completed a Marine Mammal Curation Internship at their Museum of Natural History. While boiling the bones of seals, sea lions, and porpoises and reconstructing their skeletons for display, I forged a relationship with biology professor Deborah Duffield, a pioneer in the field of cetacean genetics in the 1970s. Our conversations gave me critical insight into the perspective of scientists studying dolphins and whales in the postwar era, whose research often led them to oceanariums like Marineland.

Conversations and writing groups with my fellow history graduate students at Portland State generated many useful discussions throughout the experience of writing this thesis. Our shared experience of obtaining a graduate degree allowed me to form friendships that will last well beyond my time at PSU. In particular, I am grateful for the many conversations I had with Taylor Rose, Tanya Monthey, Katie Nelson, Jenna Barganski, Greta Smith, Alex Ritter, Will Schneider, Jeff Braytenbah, Heather Viets, Alecia Giombolini, Nicole Kindle, and Jordan Norquist, which enriched my experience as a graduate student and certainly improved the quality of this thesis.

Outside of PSU, this project received helpful suggestions from a number of conference panels and workshops. Various portions of this project benefited from questions and comments I received at the Oregon State University Environmental Arts and Humanities Graduate Conference, the Northwest Phi Alpha Theta Conference, and the PCB-AHA. My second chapter received particularly useful feedback from Marsha Weisiger, Mark Carey, Anita Guerrini, Josh Reid, Jay Taylor, Josh Howe, Lissa 
Wadewitz, Ryan Tucker Jones, and Steve Fountain during a writing workshop at the Cascadia Environmental History Collaborative Retreat. Anita Guerrini, whom I met at the Cascadia retreat, agreed to be the outside member of my thesis committee. Her perspective as an historian of science and animals improved many aspects of this project. Jason Colby's knowledge of the history of killer whale captivity provided a useful sounding board for many of my questions about the research process.

Most of the time, writing historical scholarship is an arduous and lonely task. Through the process of writing a master's thesis, I have seen value of frequent conversations and collaborations with scholars, advisors, mentors, family, and friendsand for that I am extremely grateful. 


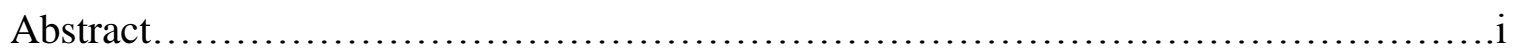

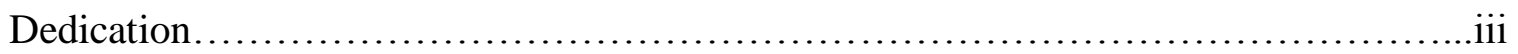

Acknowledgements..........................................................

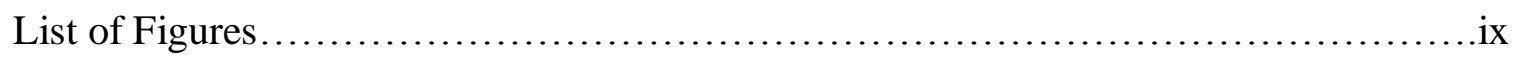

Illustrated Glossary of Cetacean Species.......................................xi

Introduction

Alice in Marineland

Chasing the White Whale Down the Rabbit Hole......................................

Chapter One

"Learning to Catch Our Own Porpoises"

Dolphin Capture, Husbandry, and Public Image at Marineland.......................14

Chapter 2

Staging the Spectacular

The Capture, Management, and Marketing of the Short-finned Pilot Whale.

Chapter 3

"The Most Vicious Animal on Land or Sea"

The Capture of a Killer Whale in Newport Harbor, California......................... 100

Epilogue

Cetacean Entertainment in the Wake of Blackfish.

Bibliography. 


\section{List of Figures}

FIGURE 1. A 1962 coloring book featuring Marineland's star pilot whale performer, Bubbles. 2

FIGURE 2. Marineland's location from the greater Los Angeles region, from a 1959 promotional brochure. 4

FIGURE 3. A map of Marineland, featuring the Sea Arena completed in 1958. 7

FIGURE 4. A bottlenose dolphin jumps through a flaming hoop during Marineland's "Porpoise Games" show. 9

FIGURE 5. The front cover of a children's storybook sold at Marineland giftshops. 11

FIGURE 6. Marineland's entrance façade. 13

FIGURE 7. Porpoise meat recipes from a U.S. Bureau of Fisheries circular, 1918. 19

FIGURE 8. Marine Studios' "tail grabber" capture device. 24

FIGURE 9. A dolphin feeding show at Marine Studios, c. 1946. 26

FIGURE 10. Marineland's founding curator Kenneth S. Norris and curator of mammals, David H. Brown. 30

FIGURE 11. A Pacific White-sided Dolphin transferred from the collecting boat to Marineland by truck, 1954. 31

FIGURE 12. Brocato and first mate Frank Calandrino haul a Pacific white-sided dolphin aboard the skiff using the breakaway hoop net. 36

FIGURE 13. Splash leaps through a flaming hoop during a Marineland show. 39

FIGURE 14. Aerial photograph of Marineland showing the construction of the Sea

Arena. 41

FIGURE 15. Curator Ken Norris feeds one of Marineland's Atlantic bottlenose dolphins, 1960. 45

FIGURE 16. Curator David Brown removes an ailing Pacific white-sided dolphin from the pool to examine it. 50

FIGURE 17. Duncan's hard work at Marineland has paid off; he has become a star. 53

FIGURE 18. Visitors could meet 'Flipper' at Marineland. 58

FIGURE 19. Stills from MGM's Sea Hunt reveal the anatomical differences between a killer whale and a pilot whale. 63

FIGURE 20. Slaughtered pilot whales on a beach in Cape Cod, c. 1885.69

FIGURE 21. Bubbles arrives at the Marineland pier, 1957. 75

FIGURE 22. An artist's rendering of Brown feeding Bubbles with tongs. 78

FIGURE 23. Bubbles performs in a Marineland show. 82

FIGURE 24. The original front cover image of the 1963 children's book, The Story of

Bubbles the Whale. 85

FIGURE 25. "Bubbles is aggressive." 89

FIGURE 26. "Warding off Bimbo with a prod." 93

FIGURE 27. Squirt and Bubbles perform in a pilot whale show at Marineland. 97

FIGURE 28. A visual representation of Eschricht's famous orca dissection, from a 1962 book by the Dutch cetologist E. J. Slijper. 106

FIGURE 29. An adult female and infant killer whale swim past the Geronimo off San

Diego in 1956.116

FIGURE 30. Wanda surfaces in the Newport Harbor turning basin. 121 
FIGURE 31. Wanda is placed on a flatbed truck for transportation to Marineland. 122 FIGURE 32. Marineland staff place Wanda into the oval display tank. 124

FIGURE 33. Wanda's skull at an offsite LA County Natural History Museum storage facility. 131

FIGURE 34. Marineland's entrance sign, featuring Bubbles the whale flanked by two Pacific white- sided dolphins. 133

FIGURE 35. Early captors believed killer whales posed little threat to humans. 135

FIGURE 36. Title cards from the 1960 silent short film The Whale That Became a Star, produced by Oceanarium, Inc. 136

FIGURE 37. An aerial view of Marineland, shortly before it closed in 1987 and a 2016 photograph of the resort that now occupies the same location. 139 


\section{Illustrated Glossary of Cetacean Species ${ }^{1}$}

\begin{tabular}{|l|}
\hline Short-beaked Common Dolphin \\
(Delphinus delphis) \\
Maximum measurements: \\
Male: 8 feet 10 inches $(2.7 \mathrm{~m})$ \\
Female: 8 feet 6 inches $(2.6 \mathrm{~m})$ \\
330 lb $(150 \mathrm{~kg})$ \\
\hline $\begin{array}{l}\text { Cuvier's Beaked Whale }(\text { Ziphius } \\
\text { cavirostris) }\end{array}$ \\
Maximum measurements: \\
23 feet (7 m) \\
Male: At least $5,700 \mathrm{lb}(150 \mathrm{~kg})$ \\
Female: About $6,600 \mathrm{lb}(3,000 \mathrm{~kg})$ \\
\hline Dalse Killer Whale $($ Pseudorca crassidens) \\
Maximum measurements:
\end{tabular}

\footnotetext{
${ }^{1}$ Illustrations by Brett Jarrett, from Thomas A. Jefferson et al., Marine Mammals of the World: A Comprehensive Guide to Their Identification (New York: Academic Press, 2008). Cetacean measurement data from Randall R. Reeves et al., National Audubon Society Guide to Marine Mammals of the World (New York: Alfred A. Knopf, 2002). Weight data of the short-finned pilot whale from "Short-Finned Pilot Whale," NOAA Fisheries Species Directory (Washington, DC, n.d.), https://www.fisheries.noaa.gov/species/short-finned-pilot-whale.
} 


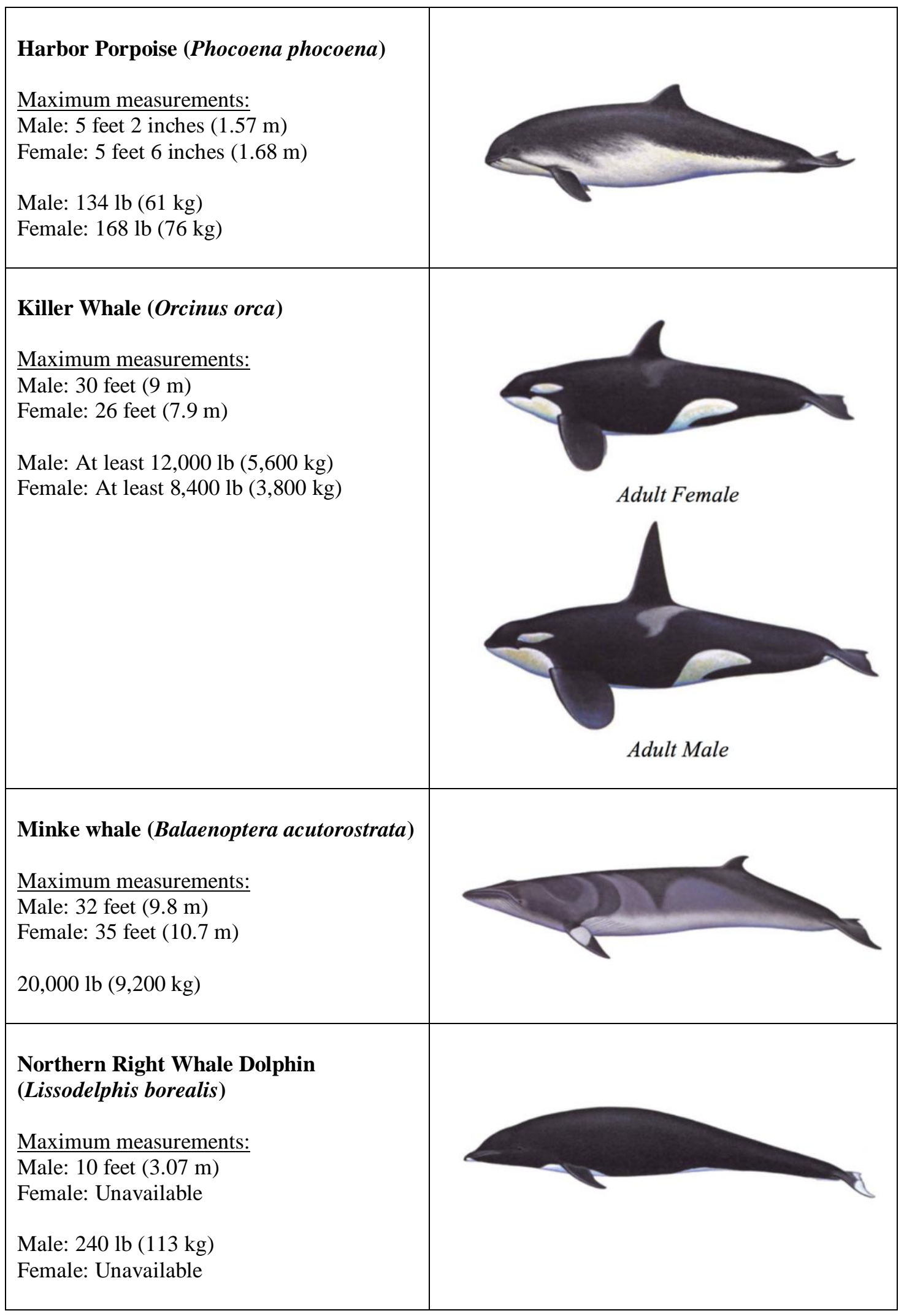




Bottlenose Dolphin (Tursiops truncatus)
Maximum measurements:
Male: 12 feet 6 inches $(3.8 \mathrm{~m})$
Female: 12 feet $(3.7 \mathrm{~m})$
Male: $1,100 \mathrm{lb}(500 \mathrm{~kg})$
Female: $570 \mathrm{lb}(260 \mathrm{~kg})$


$\underline{\text { Introduction }}$

\section{Alice in Marineland \\ Chasing the White Whale Down the Rabbit Hole}

It must have been an exciting day for ten-year-old Suzanne Blood. On the first of July 1954, the women of the Portuguese Bend Club declared Suzanne the winner of the "Alice in Marineland" competition, held on the site of the soon-to-be-completed oceanarium Marineland of the Pacific in Palos Verdes, California. A few months earlier, Marineland's general manager Ray W. Smith issued a call for "any Southland girl, between 10 and 13 years of age, whose looking glass reveals a reasonable facsimile of the fictional "Alice"" to enter into the competition. The winner would be given the honor of reigning over the pre-opening and dedication ceremonies at the park, which was due to open in August. Walt Disney's interpretation from the 1951 film Alice in Wonderland, with her distinctive blonde hair and blue dress, was clearly what the judges had in mind. A Disney studios animator even held a spot on the judges' panel. ${ }^{1}$

For the executives of Oceanarium, Inc., the sponsors of the Marineland project, evoking the fictional Wonderland from Lewis Carroll's classic children's story (and Disney's recent adaptation) was the perfect way to generate local interest in the new attraction. Alice encounters a world where the barriers between dream and reality become ambiguous and the conventional rules of the world turn upside down. Marineland of the Pacific was also a place where the impossible became possible. Visitors saw predatory sharks, rays, and ocean fish swimming together in harmony, dolphins playing basketball

\footnotetext{
1 "Marineland Begins Quest for 'Alice," Palos Verdes News, May 13, 1954, 1; “Alice in Marineland Honored at Tea," Palos Verdes News, July 1, 1954, 1.
} 
and leaping through flaming hoops, penguins riding roller-skates, and live whales singing and jumping for a handful of squid. Where else but in a fantasy realm could these animated visions of an undersea world come true? By offering audiences "a unique blend of show business and science" that promised to be "the world's greatest showplace of marine life," Marineland brought a magical and entertaining ocean theme park experience to postwar Southern Californian audiences. ${ }^{2}$

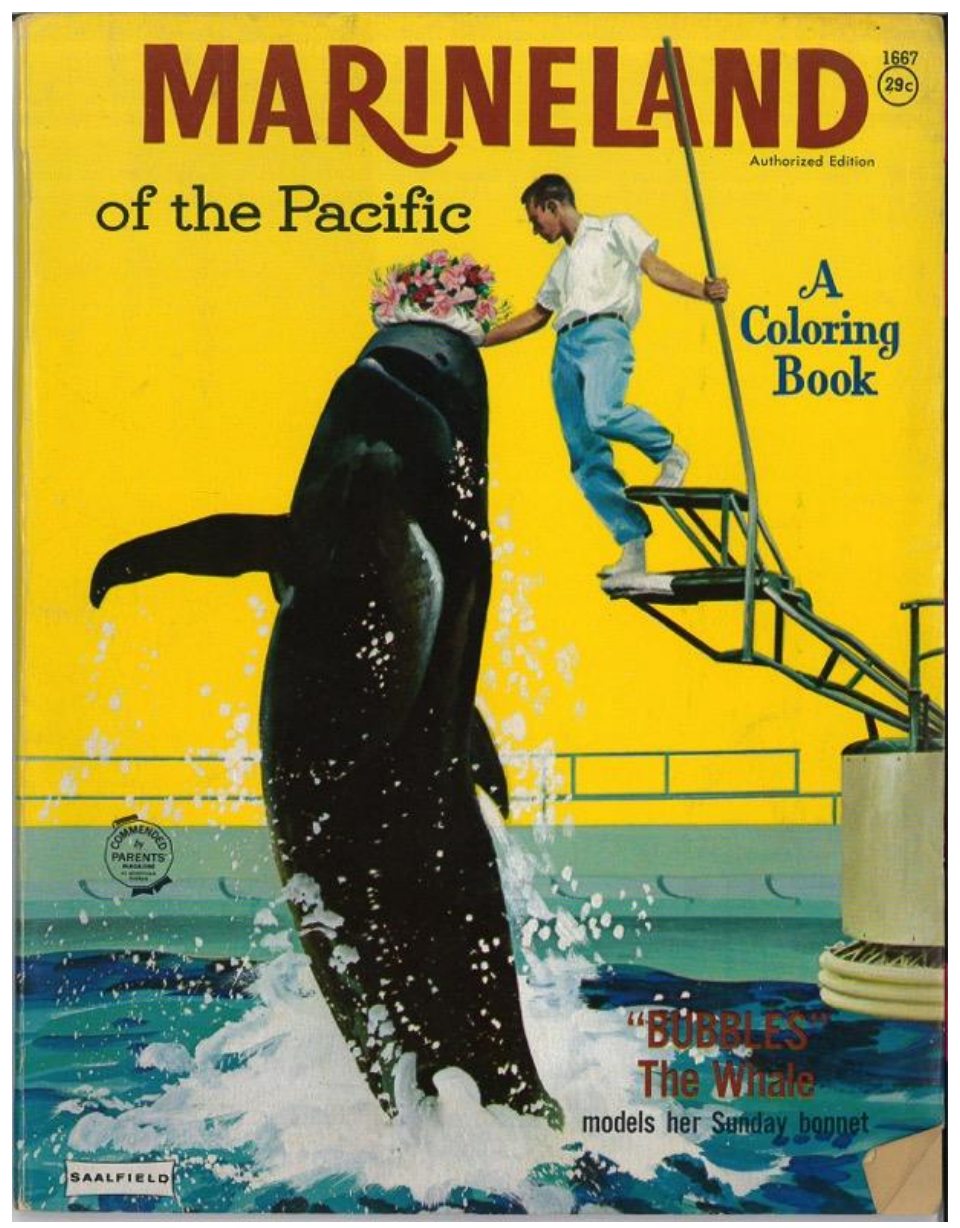

Figure 1. A 1962 coloring book featuring Marineland's star pilot whale performer, Bubbles. ${ }^{3}$

\footnotetext{
${ }^{2}$ George E. Watson, Marineland of the Pacific Souvenir Picture Book (Long Beach, California: Golden West Color Card Company, 1966).

${ }^{3}$ Marineland of the Pacific: A Coloring Book (New York: The Saalfield Publishing Company, 1962).
} 
The Los Angeles region, with its established reputation as an idyllic garden city, was well suited to provide the backdrop for the creation of a marine Eden on land. ${ }^{4}$ The concept of an "oceanarium" — an aquatic exhibit in which various animal species are housed together in a single tank, not separated as they would be in a traditional aquarium — originated in 1938 when investors from the motion picture industry founded Marine Studios south of St. Augustine, Florida. Originally intended for shooting underwater film scenes, engaging exhibits and dolphin feeding shows made the studio an immensely popular tourist attraction. After forming Oceanarium, Inc., the park's investors began developing plans for a larger facility on the West Coast. Henry Upham Harris, a New York investor and the corporation's president, along with Palos Verdes Corporation president Frank Vanderlip, Jr. selected a 65-acre tract of oceanfront property at Long Point in Rancho Palos Verdes as the site for the California park. Framed by rural hills and an expansive view of the Pacific Ocean, Marineland's "ultra modern" design produced by the architecture firm Pereira \& Luckman included two massive steel tanks, a restaurant, hotel, and an observation pier. A plant pumped ocean water filtered through sand beds at a rate of 2,000 gallons per minute to mitigate algae growth and ensure guests would always have a clear view of the oceanarium's underwater inhabitants. Over 350 viewing windows on three separate levels offered views inside the two main tanks: a 500,000-gallon oval tank kept at a constant 70 degrees Fahrenheit that housed ocean fish from California and Mexico, and a 640,000-gallon circular tank with arena seating that

\footnotetext{
${ }^{4}$ On the history of Los Angeles as Eden, see Mike Davis, "How Eden Lost Its Garden," in Ecology of Fear: Los Angeles and the Imagination of Disaster, 2nd ed. (New York: Vintage Books, 1999), 57-91; Douglas C. Sackman, "A Garden of Worldly Delights," in Land of Sunshine: An Environmental History of Metropolitan Los Angeles, ed. William Deverell and Greg Hise (Pittsburgh, Pennsylvania: University of Pittsburgh Press, 2005), 245-66.
} 
housed dolphins and later, whales. Along the corridors that surrounded the main tanks, smaller "jewel" aquariums featured animals that required more specialized environments, like Pacific octopus, sea horses, and spiny lobsters. At an initial cost of three million dollars ( $\$ 28$ million at the 2018 rate), the Marineland project represented a significant financial expenditure aimed at reproducing an authentic undersea environment. ${ }^{5}$

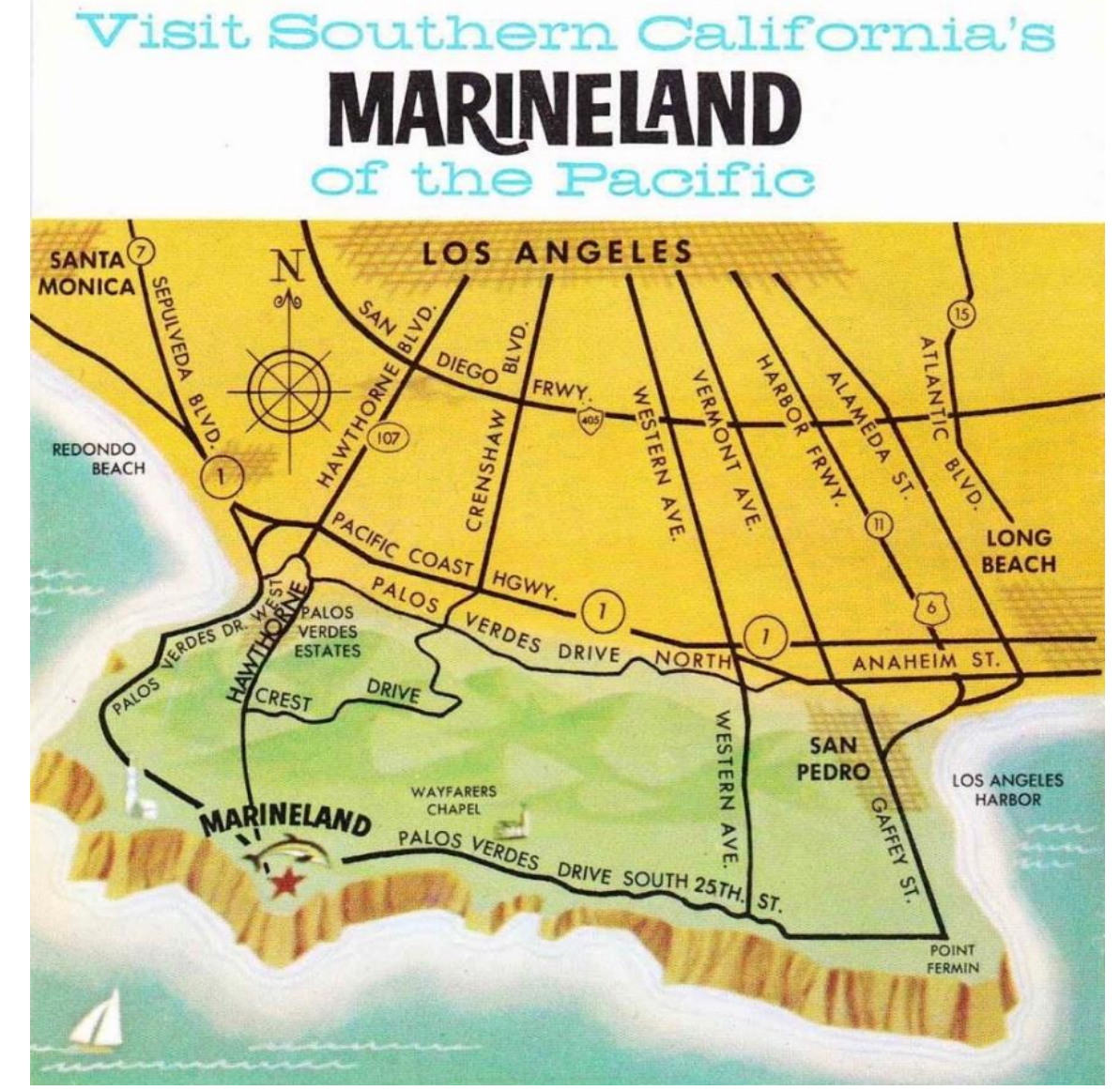

Figure 2. Marineland's location from the greater Los Angeles region, from a 1959 promotional brochure. $^{6}$

5 “"Marineland of the Pacific': Palos Verdes Site of Multimillion Dollar Project," Palos Verdes News, May 14, 1953, 1; "Gigantic Plant to Pump Over Million Gallons of Water," Palos Verdes News, August 12, 1954, 2; McFadden \& Eddy Associates, "Facts About Marineland of the Pacific Press Release" (Marineland of the Pacific, undated); "“Marineland': Palos Verdes, California," Progressive Architecture, October 1955, 106-11.

6 "Marineland of the Pacific Promotional Brochure" (Oceanarium, Inc., 1959), Author's personal collection. 
The success of Marineland's sister facility Marine Studios relied heavily on the popularity of its comedic animal acts. After discovering the performance capabilities of the bottlenose dolphin (Tursiops truncatus), trained show routines at Marine Studios' transformed the dolphin into a charismatic animal celebrity. ${ }^{7}$ Naturalistic simulations of the ocean floor were informative, but Marineland's founders, intent on establishing the park as a fixture of Southern California's tourist economy, made entertainment their central objective. "We find that the public, in general, will not pay $\$ 2.50$ to come and be educated," Marineland's chief aquarist David H. Brown declared at a public lunchtime lecture at the University of California, San Francisco in 1963. "As a result, we try to educate them and coat the salty pill of education with a little sugar." ${ }^{8}$ Competition with seaside amusement venues and popular Los Angeles destinations like Disneyland pushed Marineland's attractions further away from education and toward circus-like marine mammal performances. These carnivalesque shows, often with child audiences in mind, became the highlight of the visitor experience at Marineland.

While trained seals and sea lions had long been part of boardwalk amusement park folly, Marineland's large aquarium enclosures, financial capital, and curatorial staff allowed it to invest a significant amount of time and money procuring and exhibiting cetaceans, particularly those from the taxonomical family Delphinidae. Known to scientists as delphinids, this group is comprised of around 30 species of ocean dolphins, some of which are called whales, that often live in large social groups and use a form of

\footnotetext{
${ }^{7}$ Gregg Mitman, Reel Nature: America's Romance with Wildlife on Film (Cambridge, Mass.: Harvard University Press, 1999), 157-79.

${ }^{8}$ David H. Brown, "Marvels of Marine Mammals," Noon Topics Lecture, October 23, 1963, Carton 1, Folder 6, UCSF Committee on Arts and Lectures Collection, AR 2015-17. Archives and Special Collections, University of California, San Francisco, 4.
} 
biological sonar called echolocation. ${ }^{9}$ After Marine Studios' proved that bottlenose dolphins could indeed thrive and breed in enclosed aquarium tanks, Marineland took delphinid exhibition to a new level by inventing open ocean capture methods, developing husbandry techniques, and bringing new delphinid species into captivity. During the first decade of its existence, Marineland was the first to capture and display Northern Pacific species such as the common dolphin (Delphinus delphis) and the Pacific white-sided dolphin (Lagenorhynchus obliquidens). The collections team also pursued larger and more difficult to capture species such as the short-finned pilot whale (Globicephala macrorhyncus) and the killer whale (Orcinus orca), among the largest animals ever displayed in a North American zoological facility. As the first institution to successfully display these animals alive, Marineland familiarized audiences with these previously unknown cetaceans and captivated viewers by promoting their impressive size, intelligence, and friendliness.

\footnotetext{
${ }^{9}$ Randall R. Reeves et al., "Oceanic Dolphins," in National Audubon Society Guide to Marine Mammals of the World (New York: Alfred A. Knopf, 2002), 326-31. While some delphinids are called whales (such as killer whales and pilot whales), they are distinct from baleen whales, which tend to be much larger and possess large baleen plates instead of teeth that they use to filter fish or zooplankton from seawater. Randall R. Reeves et al., "Baleen Whales," in National Audubon Society Guide to Marine Mammals of the World (New York: Alfred A. Knopf, 2002), 184-87. The sperm whales also possess teeth like delphinids, but belong to distinct families (Physeteridae and Kogiidae). Randall R. Reeves et al., "Sperm Whales," in National Audubon Society Guide to Marine Mammals of the World (New York: Alfred A. Knopf, 2002), 238-39.
} 


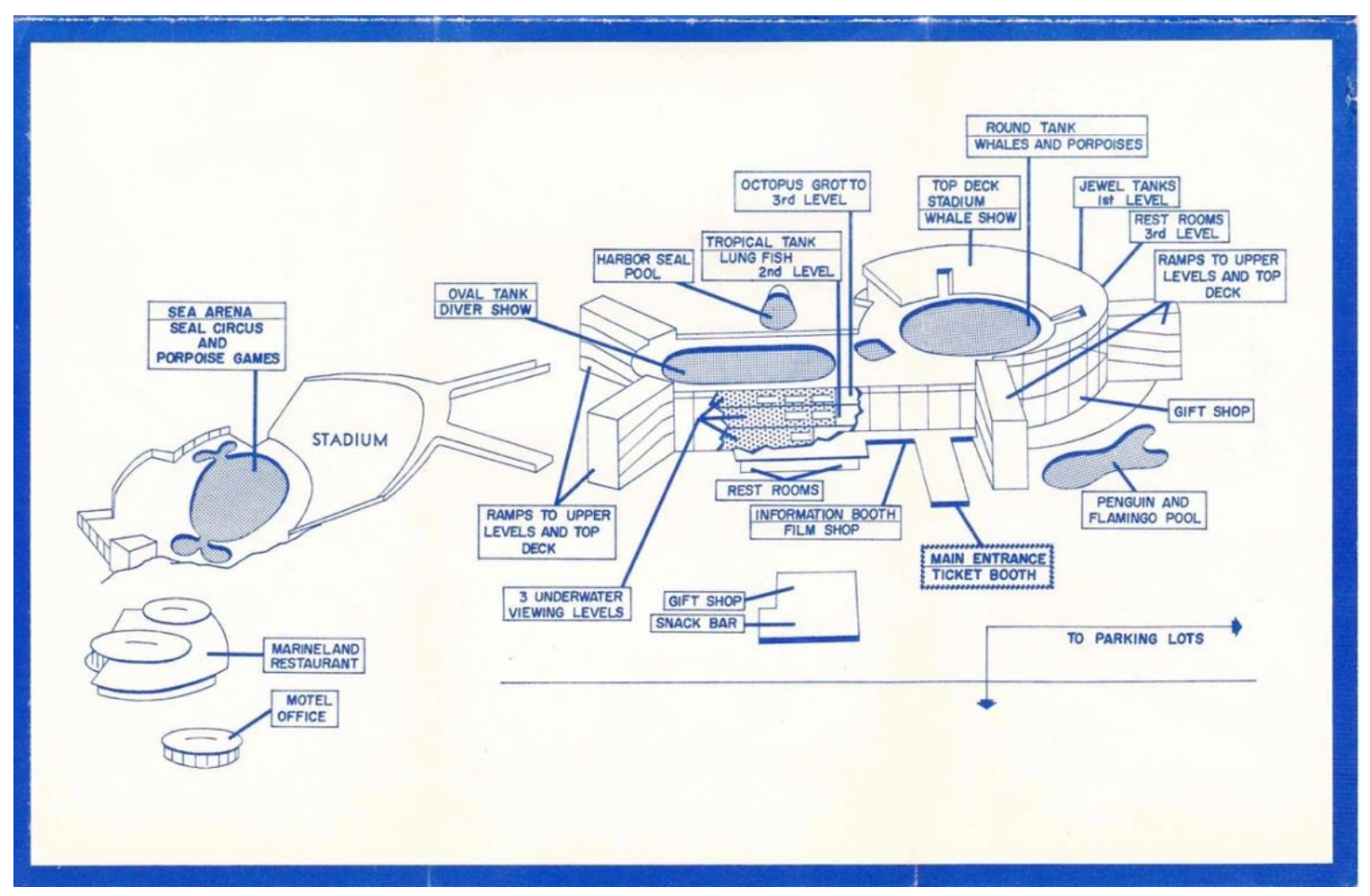

Figure 3. A map of Marineland, featuring the Sea Arena (left) completed in $1958 .^{10}$

Incorporating these unfamiliar delphinids into aquarium exhibits and trained animal acts carried significant risks, and in this sense, the use of Carrol's tale to promote Marineland's opening day became a prophetic metaphor. Wonderland exposes Alice to possibilities beyond her imagination, but she is simultaneously aggravated by nonsensical puzzles and confusing situations. For all of the park's accomplishments, Marineland's pioneering venture into cetacean captivity proved frustrating, too. In the process of developing reliable capture technologies, Marineland collectors unintentionally harmed and killed many cetaceans as they attempted to procure them. And with few medical resources to consult, Marineland's curators devised their own experimental methods to

${ }^{10}$ Marineland of the Pacific, "Information Sheet and Schedule of Events," 1959. 
cure disease, heal injuries, and manage aggressive or unruly animals. Caretakers struggled to control overt sexual behaviors and alleged animal psychoses - at times dosing dolphins and whales with tranquilizers and antidepressants — and acknowledged that the stress of performance manifested itself both mentally and physically in their cetaceans. Despite these private difficulties, curators, advertisers, and public relations staff projected the image that the dolphins and whales under Marineland's care enjoyed life in captivity and performing for an audience. Through children's literature, television appearances, and interviews with the press, Marineland created charismatic, anthropomorphized animal caricatures that allowed the park to selectively present animal behaviors that both conformed to postwar sexual morality and portrayed captivity in a positive light. Shaping audience perceptions of delphinid species reflected Marineland's guiding principle: nature could not simply be offered to the public at face value. 


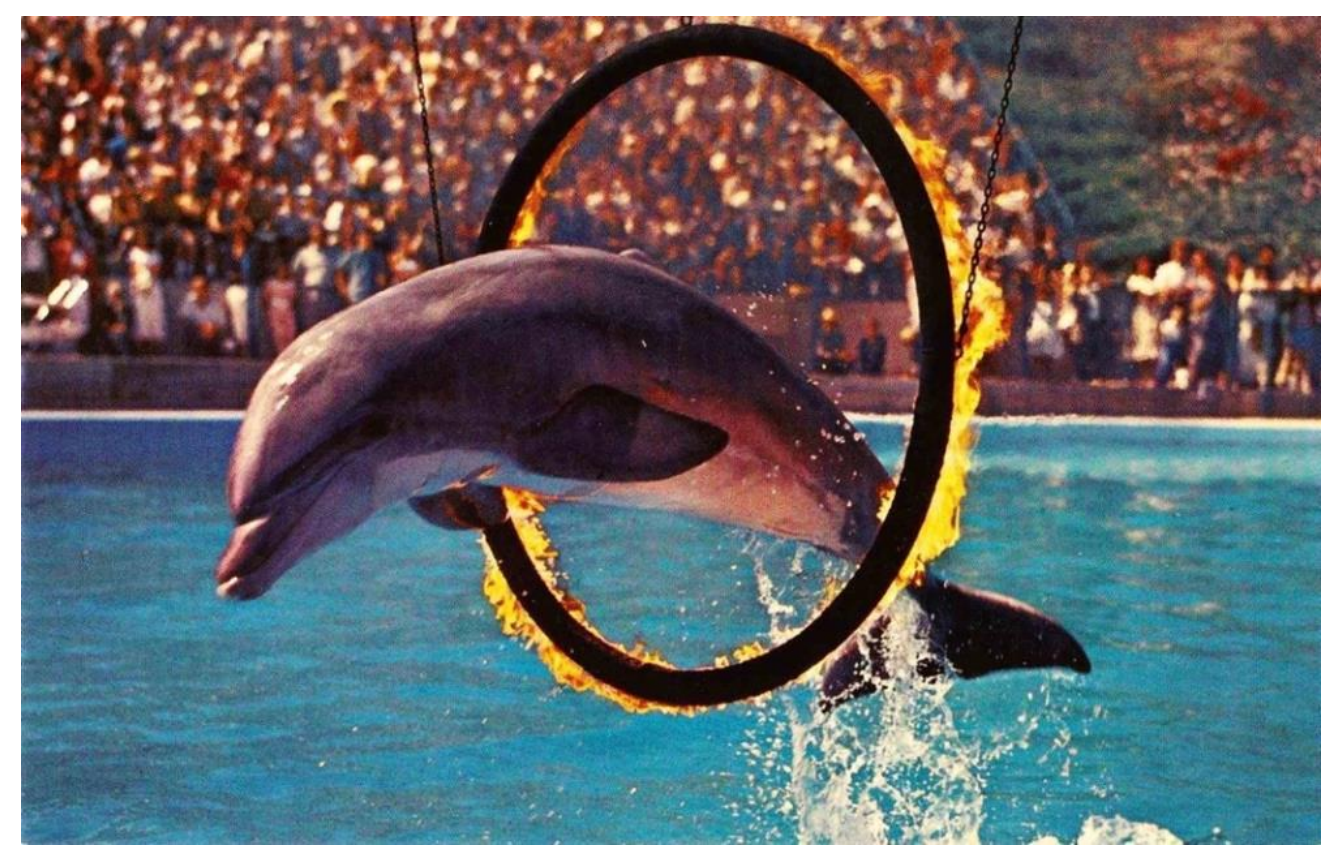

Figure 4. A bottlenose dolphin jumps through a flaming hoop during Marineland's "Porpoise Games" show. ${ }^{11}$

It is precisely this tension between perception, animal care, and entertainment that this thesis seeks to examine. Susan G. Davis' pivotal exploration of the cultural, animal, and corporate dimensions of SeaWorld in Spectacular Nature fostered scholarly interest in the marine entertainment industry that reflected growing public concern about the ethics of holding cetaceans in captivity. ${ }^{12}$ Although it represented the most significant effort by North American aquarium operators to bring an ocean-themed park to the Pacific coast during the post-World War II period, historians have largely overlooked Marineland's role in the early history of cetacean captivity and the evolving public views

\footnotetext{
${ }^{11}$ George E. Watson, “Bottlenose Porpoise Postcard” (Golden West Color Card Company, 1960), Author's personal collection.

${ }^{12}$ Susan G. Davis, Spectacular Nature: Corporate Culture and the Sea World Experience (Berkeley: University of California Press, 1997). A number of films, documentaries, and books raised questions about the ethics of cetacean captivity beginning in the late 1980s. For example, see Richard O'Barry, Behind the Dolphin Smile (Chapel Hill, N.C.: Algonquin Books, 1988); Simon Wincer, Free Willy (Warner Bros. Family Entertainment, 1993); “A Whale of a Business,” Frontline (PBS, November 11, 1997).
} 
of dolphins and whales during the twentieth century. A decade before SeaWorld opened its doors, Marineland had already solidified the popularity of captive delphinid entertainment in Southern California and beyond.

In recent decades, environmental historians and historians of science have shown how oceanariums contributed to changing perceptions of small cetaceans by familiarizing audiences with previously unknown species and allowing scientists to conduct research in a captive environment. Jason Colby's research on the capture and exhibition of killer whales in the transborder Pacific Northwest in the 1960s and 1970s has shown the profound impact public display had on cultural attitudes toward a previously detested and mysterious marine predator. ${ }^{13}$ In The Sounding of the Whale, historian D. Graham Burnett identifies ocean theme parks as important sites of scientific research on smaller cetacean species. The work of cetacean scientists in 1960s and 1970s, primarily on the intelligence, sonar, and communication capabilities of dolphins and small whales, contributed to what Burnett calls a "dramatic transformation of attitudes" among the public towards cetaceans that occurred in the twentieth century. ${ }^{14}$ This shift in perception was aided, as historian Gregg Mitman has shown, by the crafty work of marketers and film producers who worked with trainers at Marine Studios to meld bottlenose dolphins into enigmatic "pet stars." ${ }^{15}$ Marineland realized the infinite potential of delphinid

\footnotetext{
${ }^{13}$ Jason Colby, "Changes in Black and White: Killer Whale Bodies and the New Pacific Northwest," in The Historical Animal, ed. Susan Nance (Syracuse, New York: Syracuse University Press, 2015); Jason Colby, "The Whale and the Region: Orca Capture and Environmentalism in the New Pacific Northwest," Journal of the Canadian Historical Association 24, no. 2 (2013): 425-54.

${ }^{14}$ D. Graham Burnett, The Sounding of the Whale: Science and Cetaceans in the Twentieth Century (The University of Chicago Press, 2013), 521.

${ }^{15}$ Mitman, Reel Nature: America's Romance with Wildlife on Film, 157-79.
} 
personalities, along with their never-before-seen appeal, to draw larger audiences each year.

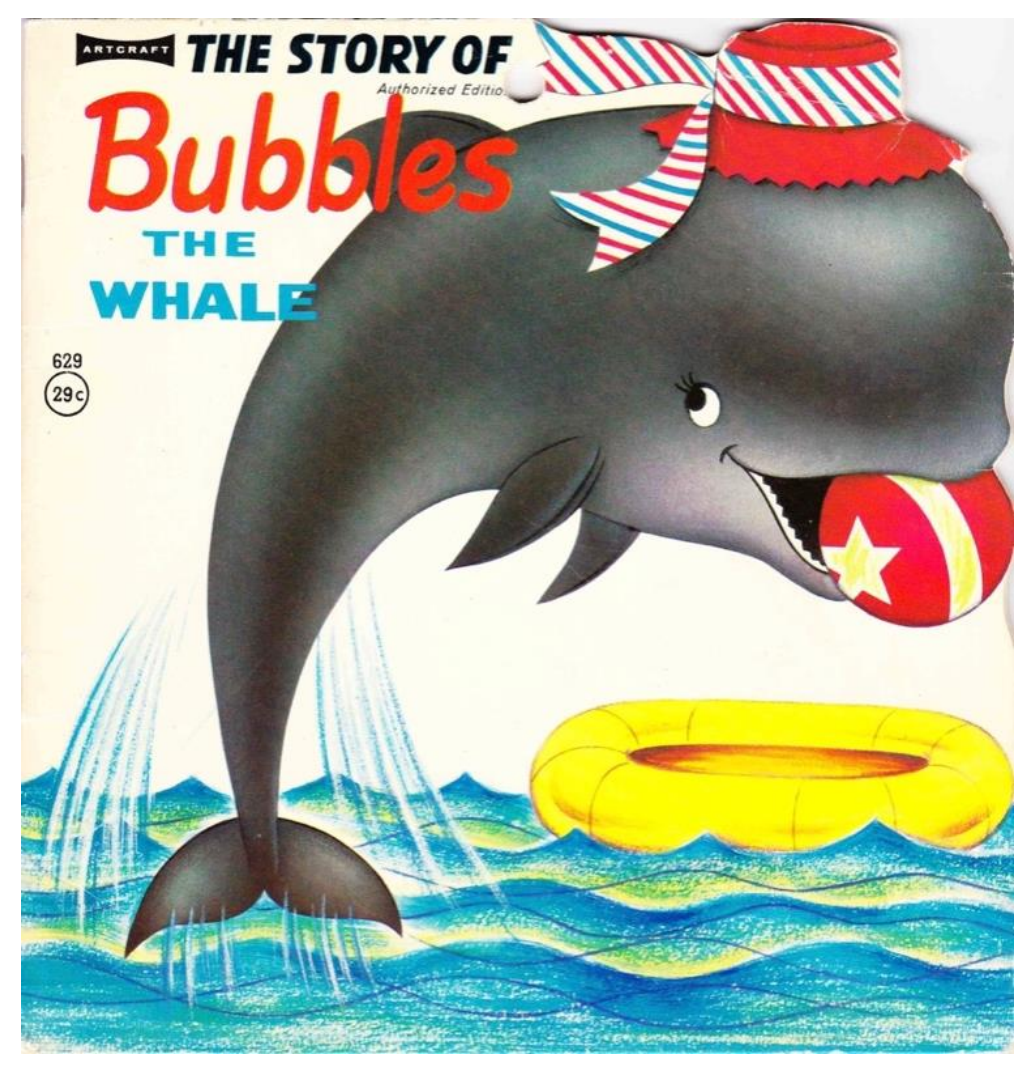

Figure 5. The front cover of a children's storybook sold at Marineland giftshops. ${ }^{16}$

In the pages that follow, this thesis examines Marineland's contributions to the development of technological methods for capturing delphinids, the burgeoning field of cetacean husbandry, and the ongoing construction of cetacean celebrities that occurred at mid-century. Each chapter focuses on a particular delphinid species (or group of species, in the case of small dolphins), placing Marineland's attempts to capture, care for, and

\footnotetext{
${ }^{16}$ Don Hackett, The Story of Bubbles the Whale, 2nd ed. (Akron, Ohio: The Saalfield Publishing Company, 1967).
} 
market these animals into the context of an evolving public relationship to cetaceans. The first chapter, "Learning to Catch Our Own Porpoises," charts Marineland's first attempts to capture and display Pacific dolphins beginning in 1954. Staff discovered that not only were open ocean dolphins more difficult to procure, they often did not adapt as readily to captivity as the hardier Atlantic bottlenose dolphins exhibited at Florida's Marine Studios. Likewise, dolphin sexual activity compromised the family-friendly, pet-like image Marineland assigned to their performing animals. Chapter Two, "Capitalizing on Cetacean Popularity," examines Marineland's capture and management of pilot whales, which were the largest cetaceans on display at the time. Although the species became a massive draw for the oceanarium, curators often struggled to control the whales' occasional aggressive behavior, refusal to perform, and sexual proclivities. Lastly, the third chapter, "The Most Vicious Animal on Land or Sea," explores the significance of Marineland's ambitious capture of a killer whale in Newport Harbor, California in 1961. At the time, no aquarium had attempted to exhibit killer whales because operators believed the species was too dangerous to contain. While the Newport orca did not survive long, Marineland's pioneering operation proved live capture was possible, paving the way for the widespread introduction of orcas to captivity in North America. 


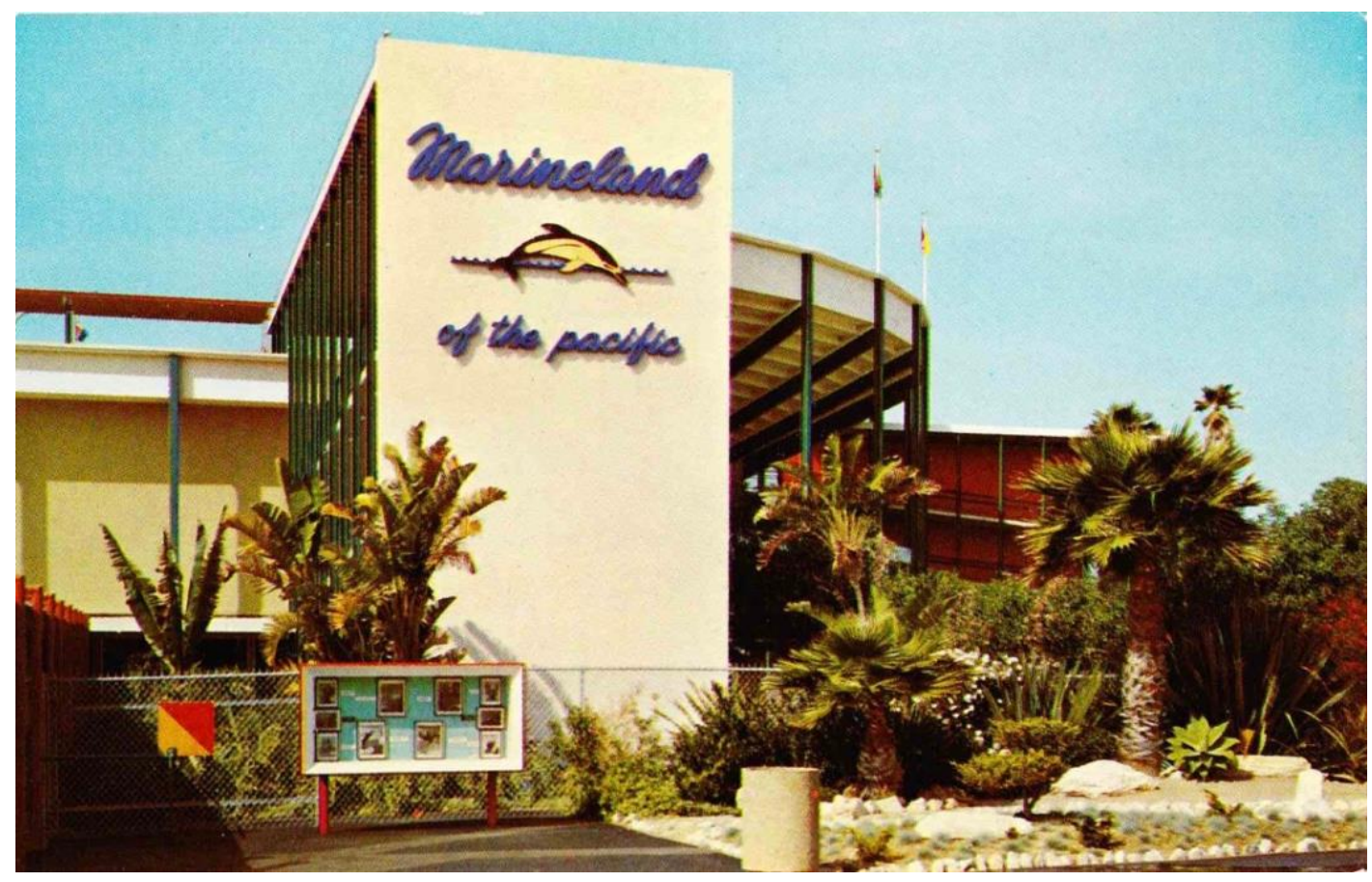

Figure 6. Marineland's entrance façade. ${ }^{17}$

During its height in the late 1950s and early 1960s, Marineland was the largest and most influential marine park on the West Coast. No aquarium could compare with its size, popularity, and most importantly, its unique delphinid exhibits that audiences could see nowhere else. Dolphin and whale exhibition made Marineland a commercial success, but the park's founders could never have predicted the challenges trainers, caretakers, and staff would have in managing these cetaceans in a captive environment.

\footnotetext{
${ }^{17}$ George E. Watson, "Marineland of the Pacific Dolphin Sign Postcard" (Golden West Color Card Company, undated), Author's personal collection.
} 


\section{Chapter 1}

\section{"Learning to Catch Our Own Porpoises"1 \\ Dolphin Capture, Husbandry, and Public Image at Marineland}

"Headline performers are the PORPOISES. They are almost human: they breathe, bear live young, nurse and care for their youngsters, are inquisitive, gentle, and they love to play."

-Oceanarium Inc. Marineland of the Pacific visitor booklet, $1964^{2}$

When Mutual of Omaha's Wild Kingdom television series premiered "In Search of a Porpoise" on a Sunday afternoon in October 1966, Americans viewed the open ocean capture of a dolphin for the first time. Host Marlin Perkins was joined by Frank Brocato and Frank Calandrino of Marineland of the Pacific's collections team, who by this time were seasoned collectors of small cetaceans. Perkins narrated the lively chase with his characteristic flair for the dramatic and a brand of Western adventurism that invoked the way cowboys might break wild mustangs on the range. The swift school of common dolphins (Delphinus delphis) that the crew pursued off the coast of Los Angeles could be captured with "combination net-lasso," "a little luck, and lots of skill," Perkins explained. In line with the family program's educational aims, Perkins peppered the episode's content with scientific facts about porpoises. In addition to their streamlined bodies and a "built-in echolocation sense," Wild Kingdom declared porpoises to be the "smartest

\footnotetext{
${ }^{1}$ Kenneth S. Norris, The Porpoise Watcher: A Naturalist's Experiences with Porpoises and Whales (New York: W. W. Norton \& Company, 1974), 51.

2 "Marineland of the Pacific Visitor Booklet" (Oceanarium, Inc., 1964), 4, Author's personal collection.
} 
mammals of the ocean." ${ }^{\prime 3}$ And because Marineland intended for the newly acquired animal to become a performer in their circus-like dolphin show, porpoise intelligence was what made the species such a worthy prize. ${ }^{4}$

The popularity and perceived intelligence of these small cetaceans was a relatively new phenomenon for American audiences, born out of the species introduction to captivity in the late 1930s. Dolphin entertainment, both at oceanariums and on film, proved to be a powerful venue for changing American perceptions of these small cetaceans. Over the course of the mid-century, the popular image of the dolphin transformed from a source of valuable oil and a pest to fishermen to a playful aquarium performer and television celebrity. This change in perception could not have occurred without the captive display of dolphins at early oceanariums like Marine Studios and Marineland of the Pacific; places that showcased dolphin entertainment and elevated the creature's cultural status to the level of what historian Gregg Mitman has called a "domesticated pet star."

As the second oceanarium in the United States and the only institution of its kind on the West Coast, Marineland of the Pacific became a pioneer of dolphin exhibition when the park opened in 1954. Following the success of its sister-oceanarium Marine

\footnotetext{
${ }^{3}$ Don Meier, "In Search of a Porpoise," Mutual of Omaha's Wild Kingdom (NBC, October 30, 1966). The popularity of Marlin Perkins' television programs (Zoo Parade, Wild Kingdom) hinged on his ability to both educate and entertain audiences by creating sense of personal involvement with wild animals. Gregg Mitman explores this in Ch. 6 ("Domesticating Nature on the Television Set") of Mitman, Reel Nature: America's Romance with Wildlife on Film, 132-56.

${ }^{4}$ Until the 1970s, cetacean scientists often used the term "porpoise" to designate any species of dolphin or porpoise, primarily to avoid confusing the species with the dolphin fish (Coryphaena hippurus), or Mahimahi. There is, however, a distinct taxonomical difference between dolphins (family Delphinidae) and the true porpoises (family Phocoenidae). Throughout this thesis, I will use the terms interchangeably, unless clarification between species is necessary.

${ }^{5}$ Mitman, Reel Nature: America's Romance with Wildife on Film, 157-79.
} 
Studios in Florida, which opened in 1938, Marineland capitalized on the growing popularity of dolphin entertainment in the United States. The park's collectors made the capture of Pacific dolphin species safer and more efficient by inventing the breakaway hoop net, which became the standard open ocean collection method for oceanariums nationwide. Yet, in the process of developing their own capture methods through trial and error, Marineland collectors harmed and killed many dolphins before mastering their techniques. The field of marine mammal husbandry was also still in its infant stages, which made caring for wild dolphins a challenge. Prior to Marine Studios, aquariums held cetaceans in captivity only sporadically, and animals seldom lived more than a few months. Having few veterinary studies to draw on, curators at Marineland often struggled to keep animals alive in captive environments, and dolphin deaths frequently occurred. Marineland staff rarely publicly divulged the difficulties they encountered while capturing, displaying, and training dolphins under their care. Rather, they presented audiences with positive narratives of captivity that reinforced the dolphin's public image as a jovial performer and a friendly human companion that was content with oceanarium life.

This chapter begins by tracing American relationships to dolphins prior to widespread captivity and then explores how early American aquariums attempted to exhibit them prior to the opening of Marineland in 1954. During the mid-twentieth century, the economic value of dolphin bodies transformed from a source of lubricating oils, hides, or meat to trained animal performers that were more profitable alive than dead. Guided by opportunism and a willingness to take risks, Marineland curators and 
staff transformed how U.S. oceanarium operators captured, cared for, and marketed dolphins, altering perceptions of dolphins on the West coast and beyond.

\section{Human-Dolphin Interactions Prior to Captivity}

Before North American aquariums began to exhibit dolphins in the mid-twentieth century, coastal entrepreneurs primarily considered 'porpoises' to be a resource for human exploitation. The head and jaw fat of dolphins could be refined into a superb lubricant that remained stable at temperature extremes, did not corrode metal, or become acidic. A market for this jaw oil-used to lubricate watches, clocks, sewing machines, and firearms - spawned the creation of a number of small shore fisheries along the eastern seaboard and the Gulf Coast during the mid-nineteenth century. ${ }^{6}$ Productive fisheries in Cape Hatteras, North Carolina and Cape May, New Jersey used seine nets parallel with the line of surf to corral schools of Atlantic bottlenose dolphins (Tursiops truncatus) to shore, where workers rendered their hides, blubber, and oil into

\footnotetext{
${ }^{6}$ For the use of porpoise oil in fine machinery, see Charles H. Stevenson, "Aquatic Products in Arts and Industries," Report of the Commissioner for the Year Ending June 30, 1902 (Washington, DC: U.S. Commission of Fish and Fisheries, 1904), 204-8; Raymond M. Gilmore, "The Whaling Industry: Whales, Dolphins, and Porpoises," in Marine Products of Commerce: Their Acquisition, Handling, Biological Aspects and Science and Technology of Their Preparation and Preservation, by Donald K. Tressler and James McW. Lemon, 2nd ed. (New York: Reinhold Publishing Corporation, 1951), 702-5. For hunting methods of American porpoise fisheries in general, see Edward Mitchell, "Porpoise, Dolphin and Small Whale Fisheries of the World: Status and Problems," Monograph (Morges, Switzerland: International Union for Conservation of Nature and Natural Resources, 1975), 84-85; A. Howard Clark, "The Blackfish and Porpoise Fisheries," in The Fisheries and Fishery Industries of the United States, ed. George Brown Goode, vol. 2, History and Methods of the Fisheries 4 (Washington, DC: Government Printing Office, 1887), 308-10. For an early twentieth century report on the chemical aspects of porpoise oil, see J. Lewkowitsch, "Dolphin Oil, Blackfish Oil," in Chemical Technology and Analysis of Oils, Fats and Waxes, 5th ed., vol. 2 (London: MacMillan and Co., 1914), 466-69.
} 
commodities. ${ }^{7}$ Porpoise leather, which shoemakers valued for its malleability and nearwaterproof qualities, made for reliable hunting or wet-weather boots. ${ }^{8}$ In the early $1880 \mathrm{~s}$, perhaps at the urging of Herman Melville's Ishmael in Moby Dick ("Porpoise meat is good eating, you know"), the Cape May Porpoise Fishing Company, seeking markets beyond oil and leather, touted porpoise as a cheaper alternative to beef. ${ }^{9}$ A New York representative of the Bureau of Animal Industry buttressed the porpoise fishery's claims, declaring: "I have tasted it and found it rather palatable... I see no reason why it should not be fairly satisfactory as food." ${ }^{\prime 10}$ Butchers experimented with bolognas and sausages of porpoise and beef, and sold the mammal's flippers from which the soup "potage fin de siecle" could be made. Red colored flesh did not betray the animal's marine origins, but the flavor might; one commentator noted "only a faint suggestion of the fishy taste." 11 Porpoise flesh never saw widespread popularity, but it remained a novelty well into the mid-twentieth century. ${ }^{12}$ A 1922 article on game fish in National Geographic written by Miami Aquarium director Louis Mowbray described the porpoise as "a swift and graceful

\footnotetext{
${ }^{7}$ For an in-depth description of the Cape Hatteras fishery, see Charles Haskins Townsend, "The Porpoise in Captivity," Zoologica: Scientific Contributions of the New York Zoological Society 1, no. 16 (1914): 29699; Roy Chapman Andrews, Whale Hunting with Gun and Camera (New York: D. Appleton and Company, 1916); "Season for Capturing Porpoises Begins Nov. 1," New York Herald, October 29, 1916. ${ }^{8}$ Charles H. Stevenson, "Utilization of the Skins of Aquatic Animals," Report of the Commissioner for the Year Ending June 30, 1902 (Washington, DC: U.S. Commission of Fish and Fisheries, 1904), 339-42.

${ }^{9}$ Herman Melville, Moby Dick, vol. 1 (London: Constable and Company, 1922), 178; "Dolphin Meat," The Brooklyn Daily Eagle, November 16, 1884.

10 "A Competitor for the 'Beef Trust,"” The Southern Planter, March 1911, 416.

11 "Bologna of Porpoise and Beef the Latest," Pittsburgh Daily Post, March 14, 1910. There appears to have been a more stable porpoise meat market along the Gulf coast of Texas during the early twentieth century, as all porpoise recipes listed in a Department of Commerce economic circular came from Texas chefs. Lewis Radcliffe, "Whales and Porpoises as Food," Economic Circular No. 38, Bureau of Fisheries (Washington, DC: Department of Commerce, November 6, 1918).

${ }^{12}$ Writing for the U.S. Fish Commission bulletin in 1885, George L. Sparks of the Cape Hatteras porpoise fishery wrote of the difficulties in establishing a market for porpoise flesh, due to "there being a certain amount of prejudice against eating it." George L. Sparks, "Porpoise Products," in Bulletin of the United States Fish Commission, vol. 4 (Washington, DC: Government Printing Office, 1885), 415-16.
} 
fish" that "when harpooned...puts up a long and thrilling battle." 13 While studying bottlenose dolphins along the Texas coast in the early 1940s, marine biologist Gordon Gunter sampled a porpoise filet; a local fishing captain informed Gunter that there was still "quite a demand" for dolphin meat in the Lone-Star state. ${ }^{14}$

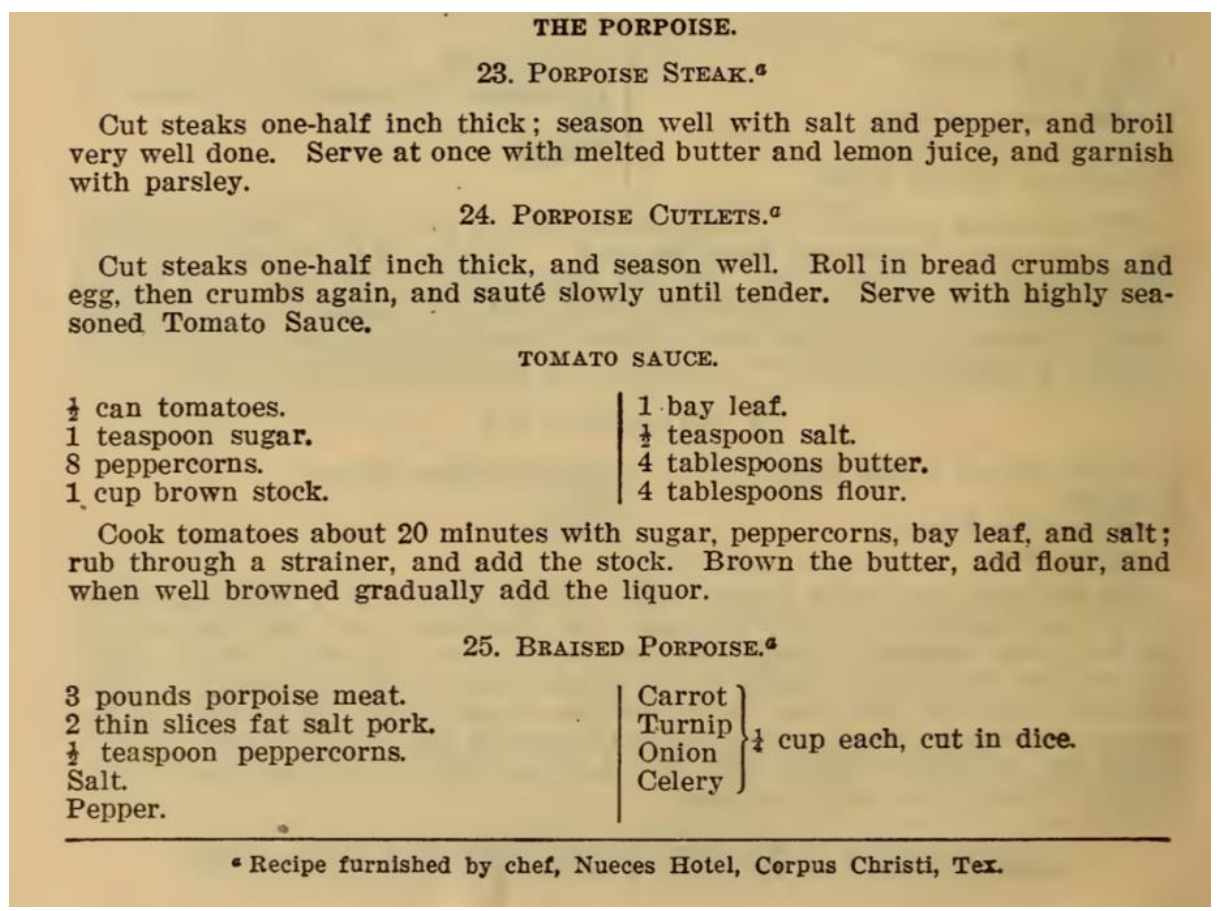

Figure 7. Porpoise meat recipes from a U.S. Bureau of Fisheries circular, 1918. ${ }^{15}$

For those that made their living from the sea, dolphins were often not a resource but a nuisance, because fishermen assumed these "herring hogs" or "puffing pigs" gobbled up innumerable quantities of fish and shrimp, tore into trawler nets, and chased

\footnotetext{
${ }^{13}$ Louis L. Mowbray, "Certain Citizens of the Warm Sea," National Geographic, January 1922, 33.

${ }^{14}$ Gordon Gunter, "Contributions to the Natural History of the Bottlenose Dolphin, Tursiops Truncatus (Montague), on the Texas Coast, with Particular Reference to Food Habits," Journal of Mammalogy 23, no. 3 (August 1942): 272. For the history of eating whale meat more generally, see Nancy Shoemaker, "Whale Meat in American History," Environmental History 10, no. 2 (April 2005): 269-94.

${ }^{15}$ Radcliffe, "Whales and Porpoises as Food," 8.
} 
away schools of tuna. ${ }^{16}$ As a result, fishermen often resorted to shooting the animals as a means of protecting their bottom line. ${ }^{17}$ Even after the species began to assume nationwide celebrity status as an oceanarium performer, some fishermen still detested the dolphin and demanded its eradication. The author of "The Sportsman" column of a Texas newspaper urged fishermen to try blasting dolphin "alarm and distress sounds" to keep the "varmints" at bay when rifles, underwater grenades, or poisons failed to eliminate them. ${ }^{18}$ Far from an object of pet-like affection for fishermen, dolphin admiration remained an object of contention even as marine entertainment industry catapulted the species to popularity. Beginning in the late 1950s, the U.S. tuna fleet utilized dolphins to locate yellowfin tuna schools in the Eastern Tropical Pacific Ocean, a technique called "fishing on porpoise." Fishermen corralled both tuna and dolphins together in purse seine nets, resulting in dolphin casualties numbering in the hundreds of thousands per year from 1959 to 1972 . Government officials did not begin to remedy the issue until the passage of the Marine Mammal Protection Act of 1972, which stipulated that the U.S. fleet meet strict bycatch quotas. ${ }^{19}$

\footnotetext{
${ }^{16}$ Gordon Gunter, "Mammals of the Gulf of Mexico," in Gulf of Mexico: Its Origin, Waters, and Marine Life, vol. Fishery Bulletin of the Fish and Wildlife Service, Fishery Bulletin 89 (Washington, DC: United States Government Printing Office, 1954), 548-49.

17 "Purpose on Porpoise," Santa Cruz Sentinel, May 4, 1941.

${ }^{18}$ Roy Swann, "Pestilent Porpoise, Destructive Dolphin," The Corpus Christi Caller-Times, February 23, 1964. For dolphin control methods used by fishermen in the North Atlantic during the mid-twentieth century, see Arthur G. Bourne, "Exploitation of the Small Whales in the North Atlantic," Oryx: The Journal of the Fauna Preservation Society 8, no. 3 (1965): 191-92.

${ }^{19}$ Dolphins and the Tuna Industry (Washington, DC: National Academy Press, 1992), 54-55; Michael L. Gosliner, "The Tuna-Dolphin Controversy," in Conservation and Management of Marine Mammals, ed. John R. Twiss and Randall R. Reeves (Washington, DC: Smithsonian Institution Press, 1999), 124. For the development of "fishing on porpoise" technique, see M. Blake Butler, "Fishing on Porpoise:' The Origins, Struggles, and Successes of the Tuna-Porpoise Controversy" (Master's thesis, University of Victoria, 2017).
} 


\section{Dolphin Exhibition Before Marineland of the Pacific}

In 1913 Charles Haskins Townsend, director of the New York Aquarium, oversaw the first successful attempt at maintaining a colony of bottlenose dolphins in a captive environment for public display. ${ }^{20}$ Townsend arrived in North Carolina that November to personally supervise a capture operation, since two earlier attempts had ended with the dolphins dying — presumably from hyperthermia—during the 400-mile journey to New York City by steamship. Using drag seine nets, porpoise fishermen from the Cape Hatteras fishery beached 63 dolphins that day, from which Townsend selected ten specimens to return with him. To prevent the animals from overheating, this time Townsend instructed his staff to place each dolphin in its own shipping tank and to replace the water whenever it became too warm or dirty with excrement. All ten dolphins made it to the aquarium alive, but five of the "half-grown" animals, which Townsend reported were "exceedingly restless and continually bruised themselves by their struggles in the shipping tanks," died soon after arriving in New York. The five adults survived. ${ }^{21}$

Despite losing half of his quarry, Townsend was pleased with how quickly the newly arrived captives adjusted to their new environment. In a New York Zoological Society publication, he proclaimed that "the New York Aquarium has a school of

\footnotetext{
${ }^{20}$ Townsend's dolphins were not the first cetaceans in captivity. Harbor porpoises were likely introduced into French private collections as early as the 1400s, and the Boston Aquarial Gardens and P.T. Barnum displayed beluga whales in the 1860s. Townsend's efforts are largely considered a success because he kept dolphins alive for longer than anyone before him. The edited volume Conservation and Management of Marine Mammals provides a chapter on marine mammal captivity, which details the history of captivity and a list of when cetacean and pinniped species were first introduced to captive environments. The authors admit that the table is not exhaustive and there are certainly factual errors. While I have noted a few inconsistencies, this is the most comprehensive list currently available. Randall R. Reeves and James G. Mead, "Marine Mammals in Captivity," in Conservation and Management of Marine Mammals, ed. John R. Twiss and Randall R. Reeves (Washington, DC: Smithsonian Institution Press, 1999), 413-16.

${ }^{21}$ Townsend, "The Porpoise in Captivity," 294.
} 
porpoises and lays claim to the world's best single exhibit of captive wild animals... No more popular exhibition of wild life has ever been made anywhere." 22 In their seven-foot deep circular pool, the dolphins splashed visitors who got too close, engaged in "boisterous play" (high-speed chases, leaps, and backwards somersaults), and frequently bunched together in what Townsend described as a "ball-like mass suggestive of the tussling of puppies." ${ }^{23}$ Foretelling later oceanariums that would imbue dolphins with a pet-like image, Townsend observed: "The visitor soon gets the impression that [dolphins] enjoy life even in captivity," and their keepers regard them "as almost domesticated animals." ${ }^{24}$ After spending seven months in the aquarium tank-with water pumped directly from the polluted New York harbor-four of the dolphins succumbed to pneumonia. The lone holdout survived for another fourteen months, before dying from a skin infection. Townsend attributed the colony's deaths directly to the sewage present in the harbor water; the species "might live much longer if pure sea water were available," he concluded. ${ }^{25}$

It took over two decades before another institution could replicate Townsend's modest success exhibiting captive dolphins at the New York Aquarium. Born out of an interest in providing a setting for underwater documentary films, in June 1938 Marine Studios opened eighteen miles south of St. Augustine, Florida. The founders William Douglas Burden, Cornelius Vanderbilt Whitney, and Ilia Tolstoy—all with connections to Hollywood-greatly underestimated public curiosity for the marine life present in their

\footnotetext{
22 Townsend, 289.

${ }^{23}$ Townsend, 289-91.

${ }^{24}$ Townsend, 292.

${ }^{25}$ Charles H. Townsend, "Endurance of the Porpoise in Captivity," Science 43, no. 1111 (April 14, 1916): 534-35.
} 
oceanarium. ${ }^{26}$ Twenty thousand visitors swarmed the park on opening day attempting to gain admittance to view the sharks, sea turtles, fish—and dolphins—inhabiting the two massive tanks architects designed to replicate the ocean floor. ${ }^{27}$ A filtration system that pumped sea water directly from the Atlantic Ocean mitigated the problem of pollution and algae growth and improved water clarity. ${ }^{28}$ Under the direction of Head Collector William B. Gray, staff netted bottlenose dolphins in coastal estuaries and shallow tidal creeks, and roped Atlantic spotted dolphins (Stenella frontalis) and common dolphins on the open ocean with a specially designed "tail grabber" device. ${ }^{29}$ Although the dolphins were only trained to jump for fish at feeding times, they proved to be an immensely popular zoological exhibit. Marine Studios made its motion picture debut in the MGMproduced Technicolor short-subject film Marine Circus in 1939, and the dolphins took center stage. Not only were they "the biggest and the fastest" species on display, they were also the "friendliest of all...as playful as a pack of puppies." 30 Playing before feature films in theatres nationwide, Marine Circus garnered valuable publicity for the park and worked to establish the dolphin as a charismatic, willing performer. ${ }^{31}$

\footnotetext{
${ }^{26}$ Ralph Nading Hill, Window in the Sea (New York: Rineheart \& Company Inc., 1956), 23. As the opening of Marine Studios approached, the journal Science described the founders' intent behind the oceanarium to be: "To portray the undersea world in natural surroundings, so that sea life under conditions as nearly identical as possible with those in which it exists in its natural state might be observed and photographed. "Scientific Events," Science 88, no. 2272 (July 15, 1938): 50.

${ }^{27}$ Hill, Window in the Sea, 48-49.

${ }^{28}$ Hill, 60.

${ }^{29}$ Marine Studios curator Forest G. Wood described the "tail-grabber" as "resembling a set of large, blunt ice tongs mounted at the end of a long pole." A line was attached to the tongs. When collectors clamped the tongs on the tail of a dolphin, the line closed in a loop and the dolphin could then be hauled to the collection boat. Forest G. Wood, Marine Mammals and Man: The Navy's Porpoises and Sea Lions (Washington, DC: Robert B. Luce Inc., 1973), 38-39.

${ }^{30}$ Pete Smith, "Marine Circus," Metro-Goldwyn-Mayer Short Story, April 1939, 15.

${ }^{31}$ On the importance of short-subject film to the early success of Marine Studios, see Mitman, Reel Nature: America's Romance with Wildlife on Film, 160-61.
} 


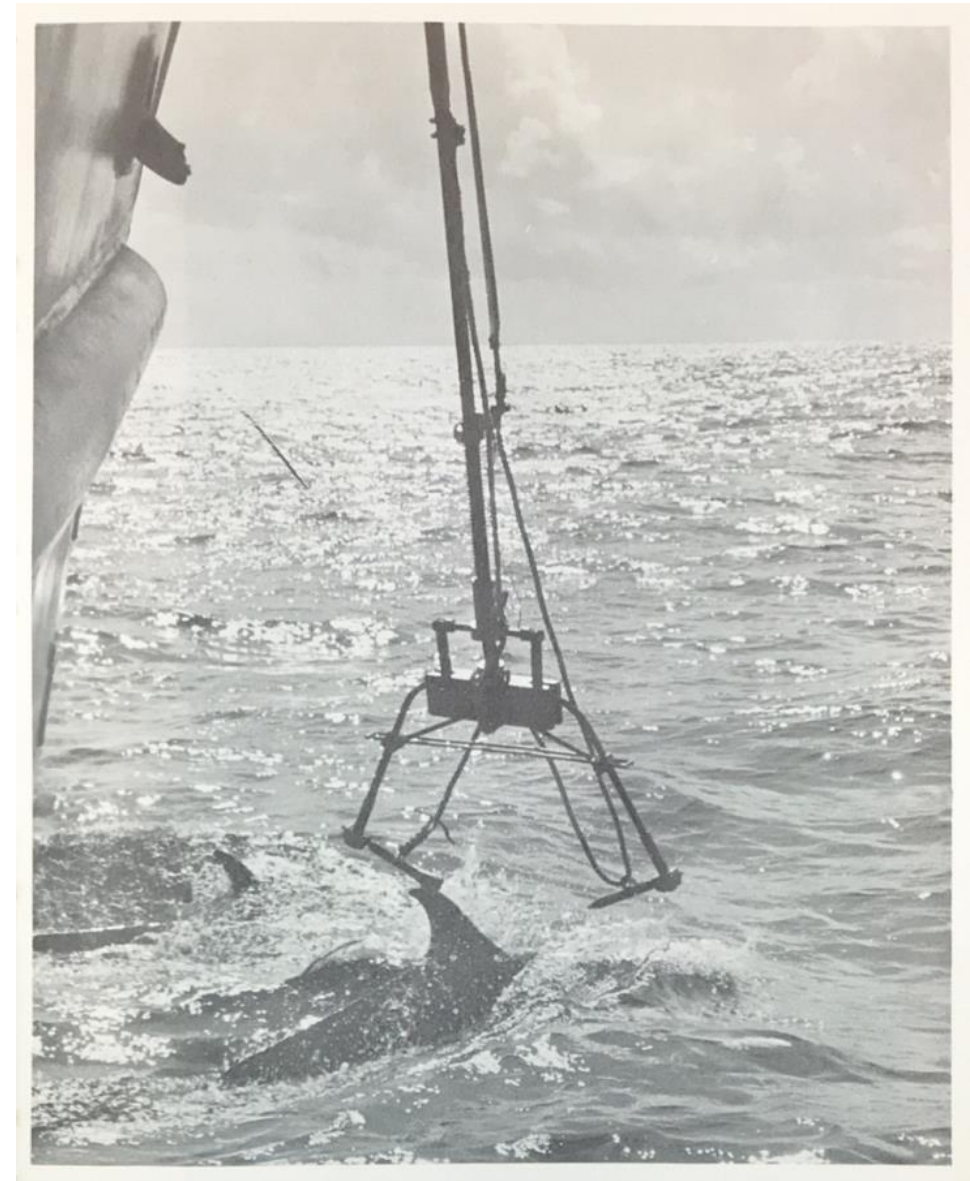

Figure 8. Marine Studios' "tail grabber" capture device. ${ }^{32}$

As staff continued to interact with dolphins in the oceanarium pools, their curiosity, parenting behavior, and seemingly high intelligence led to the first comparisons between porpoises and humans. In the January 1940 article "Meet Mr. Porpoise," Marine Studios' first curator Arthur McBride introduced readers of Natural History to dolphins as "one of their most 'human' deep-sea relatives." Porpoise mothers nursed their babies, grew distressed if staff separated them from their offspring, and "showed unmistakable signs of grief" if their young died. A month later, Life captured the first photographs of a

\footnotetext{
${ }^{32}$ William B. Gray, Porpoise Tales (New York: A.S. Barnes and Company, 1964), 39.
} 
porpoise birth. While the pregnancy ended in stillbirth, the popular magazine portrayed the event as if it were experienced by a human family. "Father hovers above," while "mother porpoise" struggles in labor. Mother doggedly attempts to bring "baby" to the surface to breathe, but an "obstetrician" in diving suit, realizing the reality of the situation, carefully removes the body from the pool. ${ }^{33}$ Early features like these originated a growing trend in popular culture of depicting dolphins as dedicated parents, whose nurturing behavior replicated the postwar domestic ideal.

The turmoil caused by the Second World War nearly forced Marine Studios to close permanently. The park's remote location, accessible only by a small coastal road, along with strict gasoline rations, forced Marine Studios to suspend operations at the onset of the war and to release their dolphins. ${ }^{34}$ Determined to see their investment thrive, the founders and directors reopened Marine Studios in 1946, replenished their stock of dolphins, and resumed the porpoise exhibit. ${ }^{35}$ In February 1947, the dolphin Mona-who had conceived at sea-gave birth to 'Spray' in the large circular tank, marking the first successful dolphin birth in captivity. ${ }^{36}$ Several subsequent live births followed, and while over half of dolphins births at Marine Studios between the period of 1939 to 1950 ended in miscarriage or stillbirth, the potential benefits for the future of the porpoise exhibit

\footnotetext{
33 "Camera at Marineland Records Delivery of the First Porpoise Ever Born in Captivity," Life Magazine, February 26, 1940, 28-29. Gregg Mitman points to the Life article as the beginning of efforts by oceanaria to domesticate the dolphin for American audiences. Mitman, Reel Nature: America's Romance with Wildlife on Film, 159.

${ }^{34}$ Hill, Window in the Sea, 65.

${ }^{35}$ Hill, 81.

${ }^{36}$ Arthur F. McBride and Henry Kritzler, "Observations on Pregnancy, Parturition, and Postnatal Behavior in the Bottlenose Dolphin," Journal of Mammalogy 32, no. 3 (August 1951): 254-55. Hill, Window in the Sea, 127, 143, 146.
} 
were immense. ${ }^{37}$ More so than wild-caught adults, "young dolphins have proven to be susceptible to being trained by humans," researchers found. ${ }^{38}$

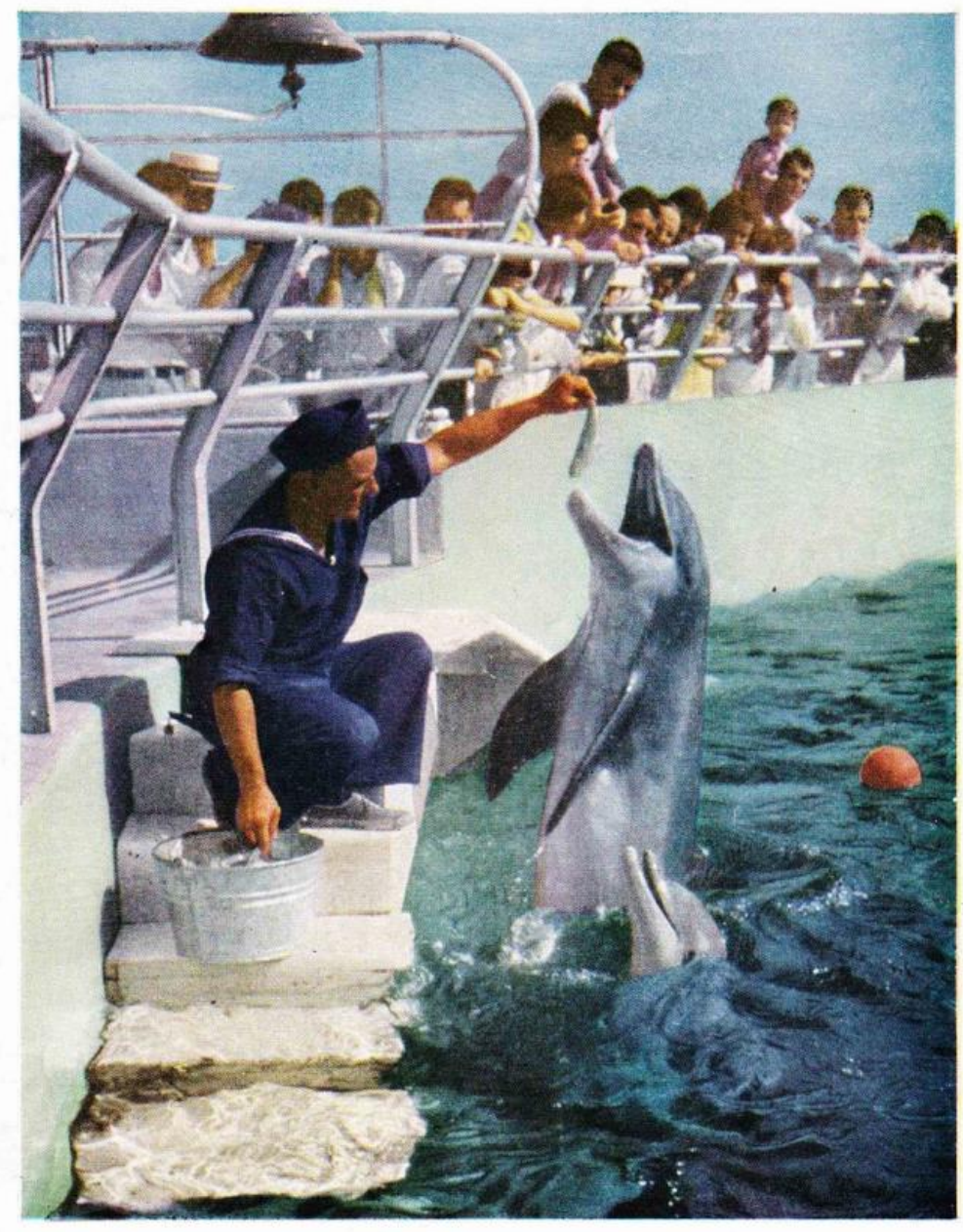

Figure 9. A dolphin feeding show at Marine Studios, c. 1946. ${ }^{39}$

The receptiveness of dolphins to training proved to be increasingly important to the continued success of Marine Studios. In 1949 founder William Douglas Burden

\footnotetext{
${ }^{37}$ McBride and Kritzler reported that from 1939 to 1950, they observed six failed dolphin births and five normal dolphin births. McBride and Kritzler, "Observations on Pregnancy, Parturition, and Postnatal Behavior in the Bottlenose Dolphin," 251.

${ }^{38} \mathrm{McBride}$ and Kritzler, 266.

${ }^{39}$ Marine Studios Promotional Booklet (St. Augustine, Florida: The Record Press, 1946).
} 
proposed that the park hire Adolf Frohn, an animal trainer from Ringling Brothers' Barnum and Bailey circus, to attempt training their dolphins to perform acrobatic routines. If the plan worked, Burden promised to have a stadium built at the park. Having only worked previously with circus animals, Frohn was unsure if dolphins could indeed be trained to perform like their terrestrial counterparts. Although it took three months to become accustomed to Frohn's presence, a young male named Flippy responded well to positive reinforcement training. ${ }^{40}$ The process took three years, but Frohn's progress resulted in the first "educated porpoise" show, which featured Flippy pulling a lanyard to raise pennant, towing a woman and a dog around on a surfboard, and bursting through a paper covered hoop. Not only did Flippy possess the intelligence to learn complex performance routines, he was friendly and gentle with human beings. "One immediately sensed the bond of friendship between the trainer and his charge," a National Geographic writer observed after watching Flippy "gratefully and delicately" accept a fish reward from Frohn. ${ }^{41}$ As for the possibility of training more dolphins like Flippy, Frohn told Natural History magazine: "Actually, he may be a dumb one!"- - hinting at the possibilities of tapping the entertainment capabilities of the porpoise brain. ${ }^{42}$ In little over a decade, Marine Studios had transformed the dolphin into a celebrity performer for which public curiosity and interest seemed almost exponential. The age of dolphin entertainment had begun.

\footnotetext{
${ }^{40}$ Hill, Window in the Sea, 177-82.

${ }^{41}$ Gilbert Grosvenor La Gorce and Luis Marden, "Marineland, Florida's Giant Fish Bowl," National Geographic, November 1952, 686.

42 John W. Dillin, "Flippy the Educated Porpoise," Natural History, April 1952, 158.
} 


\section{The Development of Dolphin Capture Methods at Marineland}

When 29-year-old Kenneth S. Norris accepted the position of curator at the future oceanarium Marineland of the Pacific in 1953, he felt woefully unprepared for the task at hand. The ex-Navy ensign held a master's degree in desert zoogeography from the University of California Los Angeles, but had recently set his eyes on researching ocean life. After breaking ground, manager Ray W. Smith directed Norris to form a collections team to ensure that the tanks would be stocked with marine life before the park opened the following year. Only two years into his Ph.D. in zoology at the Scripps Institution of Oceanography studying under the prominent fish biologist Carl Hubbs, Norris admitted having little prior experience to guide his efforts. "I didn't know a damn thing," Norris confessed in an oral history interview decades later. ${ }^{43}$ Despite his lack of experience and knowledge, Norris was determined to make the animal exhibits at Marineland a success.

An exhaustive search for a chief collector turned up the retired San Pedro fisherman Frank Brocato, a seasoned professional of Sicilian descent who was locally renowned for his ability to catch almost anything. Brocato agreed to join the team along with his godson and first mate Frank Calandrino in January 1954, which left little time to secure the fish, sea turtles, and porpoises for the park's opening day on May $15 .{ }^{44}$ In preparation for making their own captures, Norris and Brocato paid a visit to St. Augustine to study the methods used at Marine Studios. Geographically, the coast of Southern California lacked the shallow mazes of tide pools and coastal swamps that made

\footnotetext{
${ }^{43}$ Irene H. Reti and Randall Jarrell, Kenneth S. Norris: Naturalist, Cetologist and Conservationist, 19241998: An Oral History Biography (Berkeley: University of California Press, 1999), 15.

${ }^{44}$ Norris, The Porpoise Watcher: A Naturalist's Experiences with Porpoises and Whales, 37-40.
} 
netting bottlenose dolphins easy in Florida. ${ }^{45}$ The Marine Studios team loaned Marineland a tail-grabbing device, but Brocato and his team had no luck capturing Pacific dolphins with this apparatus. ${ }^{46}$

In lieu of the tail-grabber, Norris and Brocato tried a fish hook method they claimed was originally used by Pacific Northwest native tribes to catch salmon. Three size 11/0 Pflueger-Sobey brand barbless fish hooks, attached to a manila line, were taped to the end of a twelve-foot pole. Once Brocato selected a dolphin at sea, he thrust the pole at the animal's back or sides. If the hooks hit their mark, they would detach from the line and the dolphin would swim off, sometimes taking nearly two-hundred yards of line. The crew could then navigate down the line in a skiff, apprehend the hooked dolphin by its tail, and roll the animal onto a foam mattress. Once aboard the skiff, the hook wound, which led to "profuse hemorrhaging" in the majority of cases, was treated immediately. Norris used iron subsulfide to cauterize the U-shaped lesion, cleansed the site with sulfamethazine (an anti-microbial), and plugged it with sterile gauze. To help prevent further infection, penicillin was injected into the dolphin's tail fluke. ${ }^{47}$ When using the hook method, Norris found that both Common (Delphinus) and Pacific-white sided dolphins (Lagenorhynchus obliquidens) were "deeply frightened by their capture." One Lagenorhynchus died on the capture vessel "apparently from shock" before it could be brought back to the oceanarium. ${ }^{48}$

\footnotetext{
${ }^{45}$ Norris, 52-53.

${ }^{46}$ Wood, Marine Mammals and Man: The Navy's Porpoises and Sea Lions, 40.

${ }^{47}$ Kenneth S. Norris and David H. Brown, "Observations of Captive and Wild Cetaceans," Journal of Mammalogy 37, no. 3 (August 1956): 314.

${ }^{48}$ Norris and Brown, 314.
} 

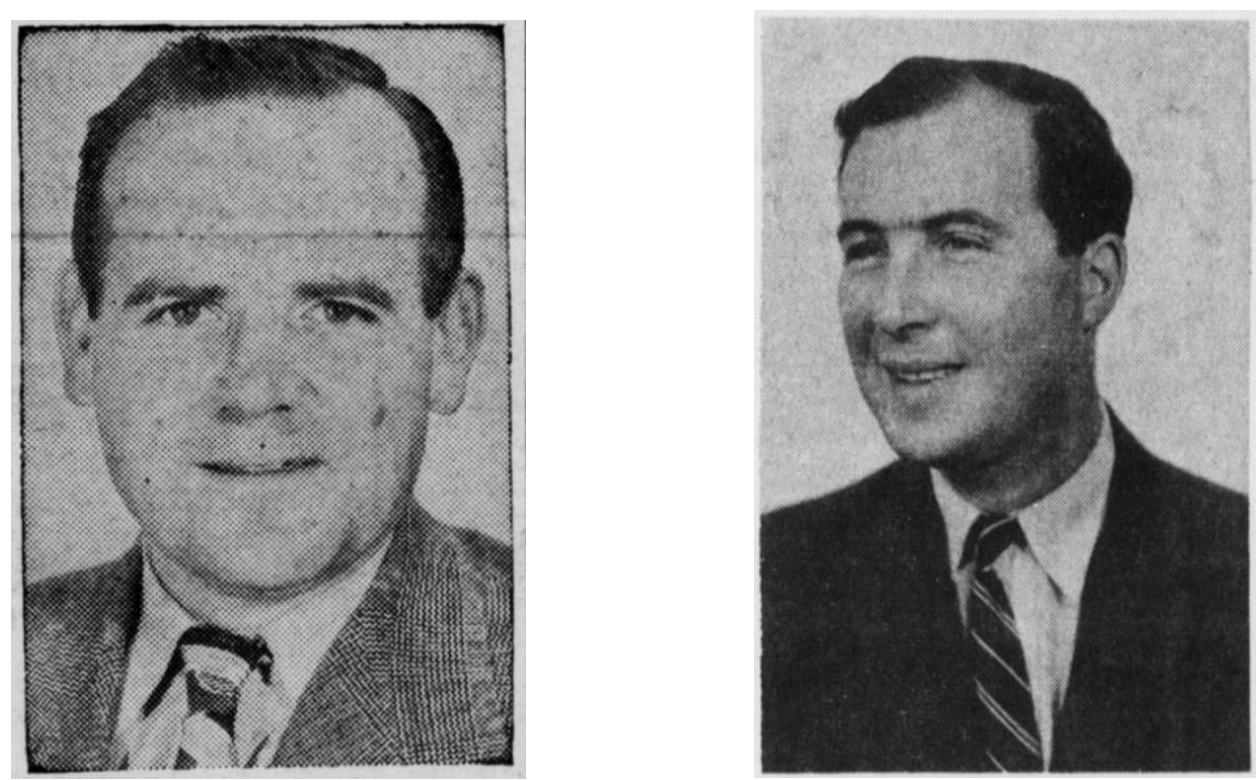

Figure 10. Marineland's founding curator Kenneth S. Norris (left) and curator of mammals, David H. Brown (right). ${ }^{49}$

Despite swift attendance to their wounds, dolphins captured by the hook method did not survive long in Marineland's holding tanks. All but three dolphins caught by this method perished. Those that returned to the park all developed abscesses at the site of the wound, which required several weeks of treatment. Each day, Norris and assistant curator David Brown (formerly an aquarist at the London Zoo) opened the abscess pockets, removed the discharge, disinfected the wound with hydrogen peroxide and an antibiotic solution, filled the cavity with erythromycin jelly, and plugged it with gauze. Norris and Brown described their treatment method as "generally effective" but healing was slow and additional abscessing frequently occurred, which the curators attributed to "poor circulation in the blubber." 50

\footnotetext{
49 "Curator," Palos Verdes News, February 11, 1954, 1; "Mammal Curator Talks to Science Clubbers," Palos Verdes News, April 22, 1965, 2.

${ }^{50}$ Norris and Brown, "Observations of Captive and Wild Cetaceans," 314-20.
} 


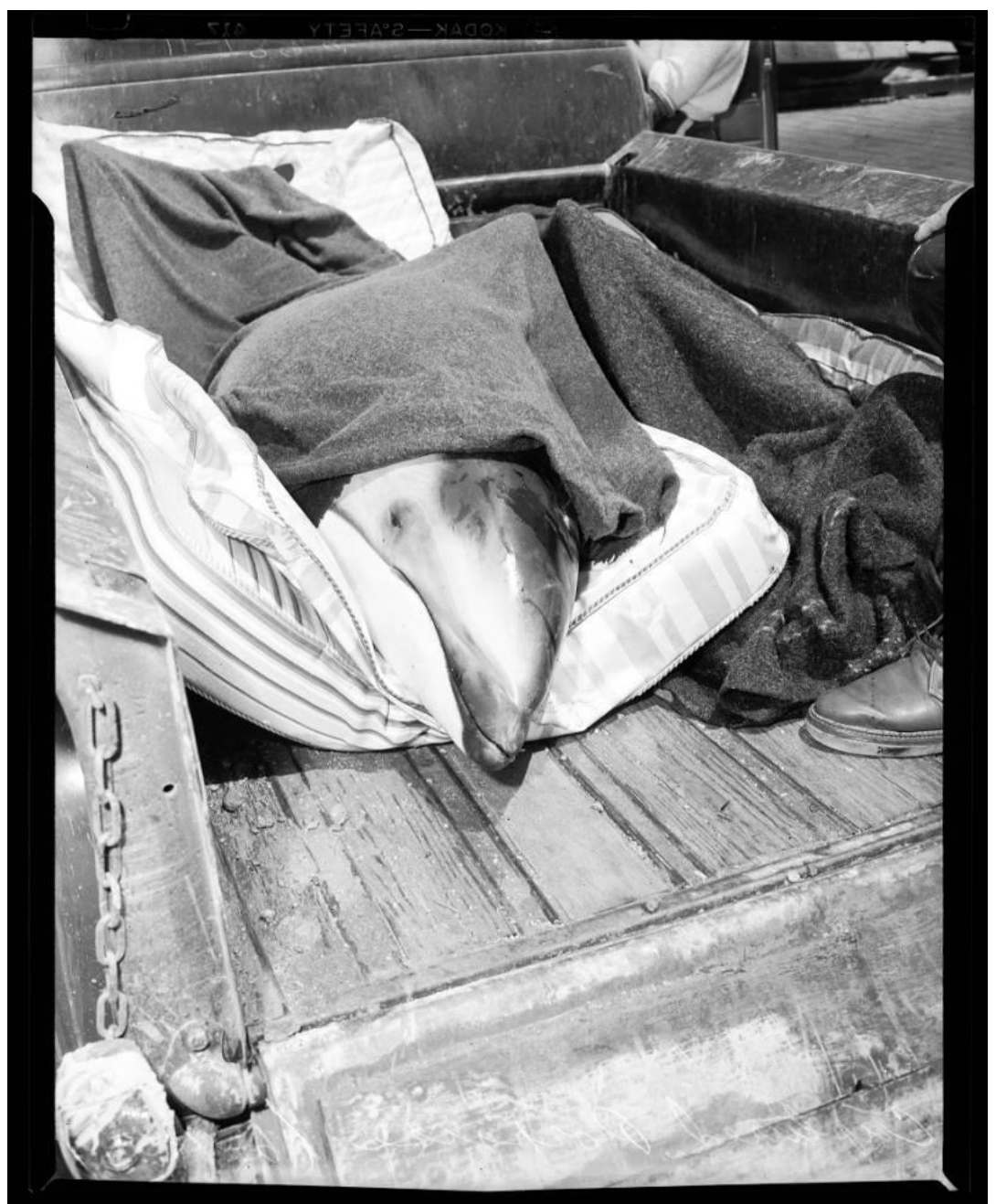

Figure 11. A Pacific White-sided Dolphin transferred from the collecting boat to Marineland by truck, $1954 .{ }^{51}$

The brief captivity of Pauline, a Common dolphin caught the summer before opening day (and the park's first dolphin capture) illustrates the some of the difficulties Marineland's staff encountered during their first forays into dolphin husbandry. Captured with fish hooks in the nearby Catalina Channel (the waterway between mainland Southern California and Santa Catalina Island) in July 1954, Pauline returned to

\footnotetext{
${ }^{51}$ Porpoise being transferred to Marineland of the Pacific Aquarium, 1954, June 8, 1954. Los Angeles Examiner Photographs Collection, 1920-1961, University of Southern California.
} 
Marineland in an advanced state of shock, unable to stay above water without the assistance of staff. An injection of adrenaline had no effect. After holding her above water for a few hours, staff devised "dolphin water wings" (four gallon-sized jars attached to her sides) to prevent Pauline from drowning. After "floating helplessly" for two days, the collections team captured a male Common dolphin and placed him in the tank with Pauline. The male immediately began to interact with the female, so staff removed the water wings. Norris reported that the two animals were "inseparable" until Pauline's death two months later. A necropsy revealed that an additional abscess had formed beneath the scar tissue of the original hook wound and likely caused her death. After losing Pauline, her male companion "circled her body whistling constantly," Norris and Brown described in a scientific report. Despite the company of four Pacific whitesided dolphins, the male thereafter refused food and "ceaselessly" circled the perimeter of the tank until he was found dead three days later. ${ }^{52}$

Although Norris managed to display a small group of Pacific white-sided dolphins on opening day, a contract with Marine Studios ensured that bottlenose dolphins - a species with a consistent record of thriving in captivity and responding quickly to training —-would soon be a part of Marineland's collection. ${ }^{53}$ On September 14, 1954 Atlantic bottlenose dolphins Frankie, Floyd, Mabel, and Myrtle journeyed by plane to Palos Verdes, marking the first time live cetaceans were shipped by air. ${ }^{54}$ Marine

\footnotetext{
${ }^{52}$ Norris and Brown, 319-20. During the park's early years, Marineland did not have professional veterinarians on staff. Therefore, curators brought cetaceans that died at Marineland to the Los Angeles County Livestock Department, where livestock veterinarians conducted necropsies to determine the cause of death.

53 “To Marineland's Training Tank/Marineland of the Pacific to Open Saturday, August 28," Palos Verdes News, August 26, 1954, 1-2.

54 "4 Jumping Porpoises Flown Here from Florida," Los Angeles Times, September 15, 1954, 25.
} 
Studios curator Forrest Wood, who accompanied the captives for the twelve-hour flight, wet the dolphins every ten minutes to prevent them from overheating. This method of transport, developed at Marine Studios, entailed lying a dolphin on its side in a rubber bag supported by a box-like wooden frame. A mattress or cushion was placed underneath the bag to provide support, and a pressure sprayer connected to water tanks was used to keep the dolphins cool. ${ }^{55}$ Although Mabel and Myrtle were wild caught, the males Frankie and Floyd were born three days apart at Marine Studios in 1950. ${ }^{56} \mathrm{~A}$ few days after arriving at Marineland, the foursome began to take food from a trainer's hand, and soon they were plucking a fish dangling from a trainer's teeth. By October, the dolphins were performing five feeding shows a day. ${ }^{57}$

Although the generosity of its sister oceanarium had sustained Marineland's dolphin exhibit by providing the park with healthy and tractable animals, Norris knew that importing dolphins from Florida — especially due to the excessive cost—could only be a temporary solution. ${ }^{58}$ To ensure the long-term success of Marineland's dolphin enterprise, collections staff would have to learn how to capture wild dolphins without inflicting deadly capture wounds. Abandoning the salmon hook method, Brocato began experimenting with a "head grabber" that could be plunged into the water in front of a

\footnotetext{
${ }^{55}$ Wood, Marine Mammals and Man: The Navy's Porpoises and Sea Lions, 46-47; Hill, Window in the Sea, 198-200.

${ }^{56}$ Sam Ridgway and Kurt Benirschke, "Breeding Dolphins; Present Status, Suggestions for the Future," U.S. Marine Mammal Commission (Washington, DC: Zoological Society of San Diego, November 1977), 57.

${ }^{57}$ Norris, The Porpoise Watcher: A Naturalist's Experiences with Porpoises and Whales, 56; "Make Porpoise History Flying from Florida," Palos Verdes News, October 7, 1954, 5.

${ }^{58}$ On the importation of dolphins from Marine Studios, Norris would later write: "This, we knew, was only a temporary solution, because it was simply too expensive to fly these animals in whenever we needed to develop a new show." Norris, The Porpoise Watcher: A Naturalist's Experiences with Porpoises and Whales, 56.
} 
swimming dolphin. A net bag with a slip noose was attached to a steel hoop with breakaway twine at the end of a long pole. When a dolphin swam through the hoop, its head would be snared by the net bag, which would break away from the device. A strong line was fastened to the net, so collectors simply could wait until the dolphin tired itself out before hauling it onto a mattress on the skiff. ${ }^{59}$ A year after Marineland opened, general manager Ray W. Smith lauded Brocato's device as a "humane method for bringing in dolphins alive and uninjured." 60 The technical details of this "kinder" form of porpoise capture, however, were a closely guarded secret. ${ }^{61}$ "We can't tell about it," Brocato told the Coronado Journal; "We have applied for a patent, and if we told what the catcher is, anyone could make one and we'd be out of luck."62 Brocato's invention remained a company secret for the time being, but by the late 1960s the breakaway hoop net would become the industry-wide standard for capturing small delphinids on the open ocean. ${ }^{63}$

In 1956, Norris and the collections team turned their sights to the Pacific bottlenose dolphin, the same genus as the Marine Studios dolphins staff had successfully trained for the circular tank show. Much like their Atlantic counterparts, Pacific Tursiops consist of distinct coastal, inshore groups and pelagic, offshore populations. ${ }^{64}$ In

\footnotetext{
${ }^{59}$ Wood, Marine Mammals and Man: The Navy's Porpoises and Sea Lions, 40; Norris also described this method of dolphin capture (albeit not the technical specifications of the device) in Kenneth S. Norris, "Collecting for the World's Largest Fishbowl," Natural History, March 1957, 125, 161.

60 "Marineland Invents Device for Nabbing Fast Dolphins," Valley News, August 18, 1955, 4.

61 "Makes Catching Porpoises Kinder," Palos Verdes News, August 18, 1955, 5.

62 "High Tide," Coronado Journal, August 25, 1955, 1.

${ }^{63}$ In 1973, Forrest Wood described the breakaway hoop net technique as the "standard capture equipment for the smaller pelagic cetaceans, at least in the United States." Wood, Marine Mammals and Man: The Navy's Porpoises and Sea Lions, 40; Edward D. Asper, "Techniques of Live Capture of Smaller Cetacea," Journal of the Fisheries Research Board of Canada 32, no. 7 (1975): 1193.

${ }^{64}$ Randall R. Reeves et al., "Common Bottlenose Dolphin," in National Audubon Society Guide to Marine Mammals of the World (New York: Alfred A. Knopf, 2002), 358-59.
} 
September 1956, the team smoothly captured a female offshore bottlenose in the San Pedro Channel using the recently refined porpoise snare. ${ }^{65}$ But the coastal San Diego Bay bottlenose population, which Norris remembered seeing often during his early days at the Scripps Institution, "seemed easier to catch" since they came so close to shore. ${ }^{66}$ To make matters more pressing, Marineland executives had plans to expand the park by creating a new 'Sea Arena' pool to showcase a new trained dolphin show. "We were anxious to perfect methods of capturing this animal as we expect it to be the mainstay in trained sets for the future Sea Arena," Norris wrote in his field notes. ${ }^{67}$

${ }^{65}$ Kenneth S. Norris and John H. Prescott, Observations on Pacific Cetaceans of Californian and Mexican Waters, vol. 63, University of California Publications in Zoology 4 (Berkeley: University of California Press, 1961), 318.

${ }^{66}$ Norris, The Porpoise Watcher: A Naturalist's Experiences with Porpoises and Whales, 58.

67 "Kenneth S. Norris Field Notes," n.d., 297, Kenneth S. Norris Papers UA 66, University of California Santa Cruz Special Collections and Archives. 


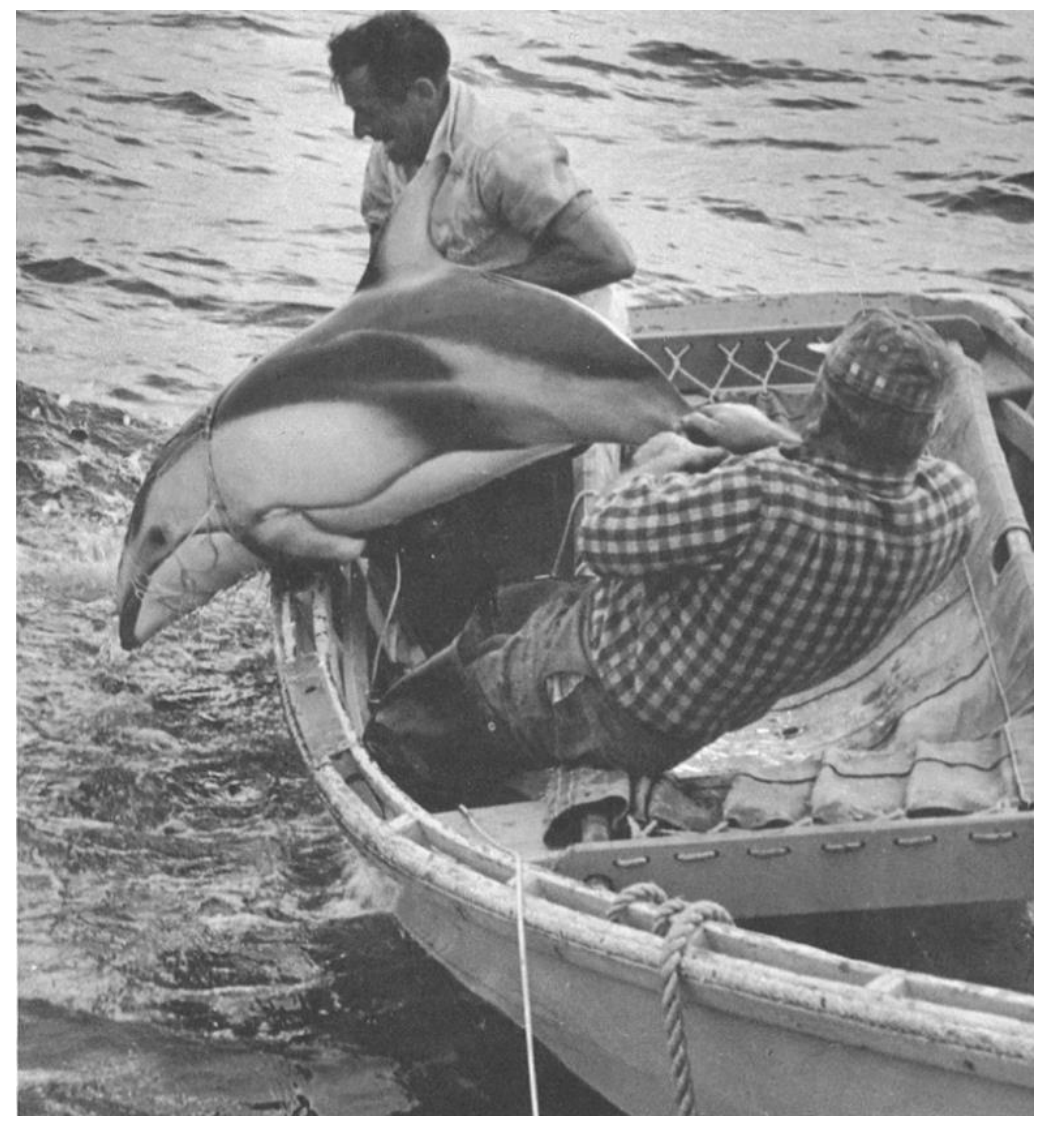

Figure 12. Brocato and first mate Frank Calandrino haul a Pacific white-sided dolphin aboard the skiff using the breakaway hoop net. ${ }^{6}$

While the fish hook method clearly had dangerous implications for the dolphins involved in the capture process, Norris and the capture team soon discovered that large net operations — which had been used to successfully by Marine Studios in shallow estuaries and swamps — could also prove fatal for dolphins captured in Pacific waters. Norris, Brocato, and Calandrino first took a trip to the San Diego Bay in late November 1956 to observe the movement patterns of the inshore population. Norris believed that the resident group of approximately 25 to 30 animals had "developed a culture of sorts,

\footnotetext{
${ }^{68}$ Lou Jacobs, Jr., Wonders of an Oceanarium: The Story of Marine Life in Captivity (San Carlos, California: Golden Gate Junior Books, 1965), 41.
} 
attuned to the niceties of life in a busy port," often following Navy garbage ships to feed on fish attracted to the trash the ships dumped outside the bay. ${ }^{69}$ Abandoning the snare in hopes of capturing the animals in greater numbers, the team attempted capturing Pacific Tursiops in the upper bay with a 1200-foot nylon gill net, which the Geronimo circled around a traveling school. At this point, cetacean research had not yet confirmed that dolphins possessed the ability to echolocate, leaving Norris and his team perplexed when a group of dolphins effortlessly escaped through the unclosed portion of the gill net in murky water. "It was as if they were above-water looking down on the whole operation," Norris recalled. ${ }^{70}$

Making matters worse was that certain members of the school, Norris believed, had learned to recognize the sound of the Geronimo's engine. "Old Scarback," a large male the team had nicknamed for the deep cuts on his dorsal fin, was presumed to be the group's sentry. "At times when stalking the school," Norris remembered, "we could see Old Scarback lay over at the surface looking at us with one eye, and usually the school then became unapproachable." ${ }^{71}$ But in January 1957 the collections team caught the school off-guard as it swam north along Silver Strand toward the opening of the bay. By holding the dolphins along the surf and keeping ahead of them, the team was able to drop the net and corral the entire group of ten animals. Brocato eventually separated the school in half by dividing the net into a clover leaf. Unexpectedly, one lobe of the net collapsed in the outgoing tide, trapping five animals underneath it, including Old Scarback. Old Scarback and another male managed to escape the heavy net, but the three remaining

\footnotetext{
${ }^{69}$ Norris, The Porpoise Watcher: A Naturalist's Experiences with Porpoises and Whales, 59-60.

${ }^{70}$ Norris, 60-61.

${ }^{71}$ Norris, 61.
} 
animals were still trapped. As Norris, Brocato, and the rest of the team dragged the portion of net aboard, they found that two animals - a juvenile male and an adult female — had drowned. Staff apprehended the remaining dolphin, a ten-foot female, and returned her to Marineland. ${ }^{72}$ Reasoning that "discretion is the better part of valor," Norris let the other half of the school escape. ${ }^{73}$

A year before the San Diego bottlenose capture, Ray Smith had resigned as Marineland's general manager. Oceanarium Inc. appointed its treasurer, 35-year-old William F. Monahan, to replace Smith. ${ }^{74}$ Monahan, a graduate of Pittsburgh's Robert Morris School of Business, brought a new desire to play up Marineland's carnivalesque family atmosphere and attract further public attention with spectacle. The oceanarium's "New Look," the Palos Verdes News reported in November 1956, "is designed to bring to young and old hearts the feeling of outdoor fun combined with outstanding show entertainment." Instead of regular feeding shows, the four Atlantic bottlenose dolphins now played basketball games five times a day and hurtled 20 feet in the air to receive treats. A 400-pound black giant sea bass (Stereolepis gigas) named "Big Bertha" became the "new leading lady" of the underwater feeding shows in the oval fish tank. Penny, "the first of the Marineland penguins to be tamed," was taught to roller-skate and raise a flag. ${ }^{75}$ In February 1957, the collections team had achieved the first open ocean capture of a 12-foot short-finned pilot whale (Globicephala macrorhynchus) in the Catalina

\footnotetext{
72 Norris and Prescott, Observations on Pacific Cetaceans of Californian and Mexican Waters, 63:316; "Kenneth S. Norris Field Notes," 299.

73 "Kenneth S. Norris Field Notes," 300.

74 “Ray Smith Resigns at Marineland," Palos Verdes News, January 26, 1956, 1.

75 "Spectators Thrill Daily to Antics," Palos Verdes News, November 8, 1956, 19; “They're Big, and So's Their Home," Palos Verdes News, August 16, 1956, 6.
} 
Channel with a modified, larger porpoise snare. Faced with competition from the recently opened Disneyland amusement park in nearby Anaheim, Marineland operators aimed to attract Southern Californian tourists with dramatic animal exhibits that could rival a theme park.

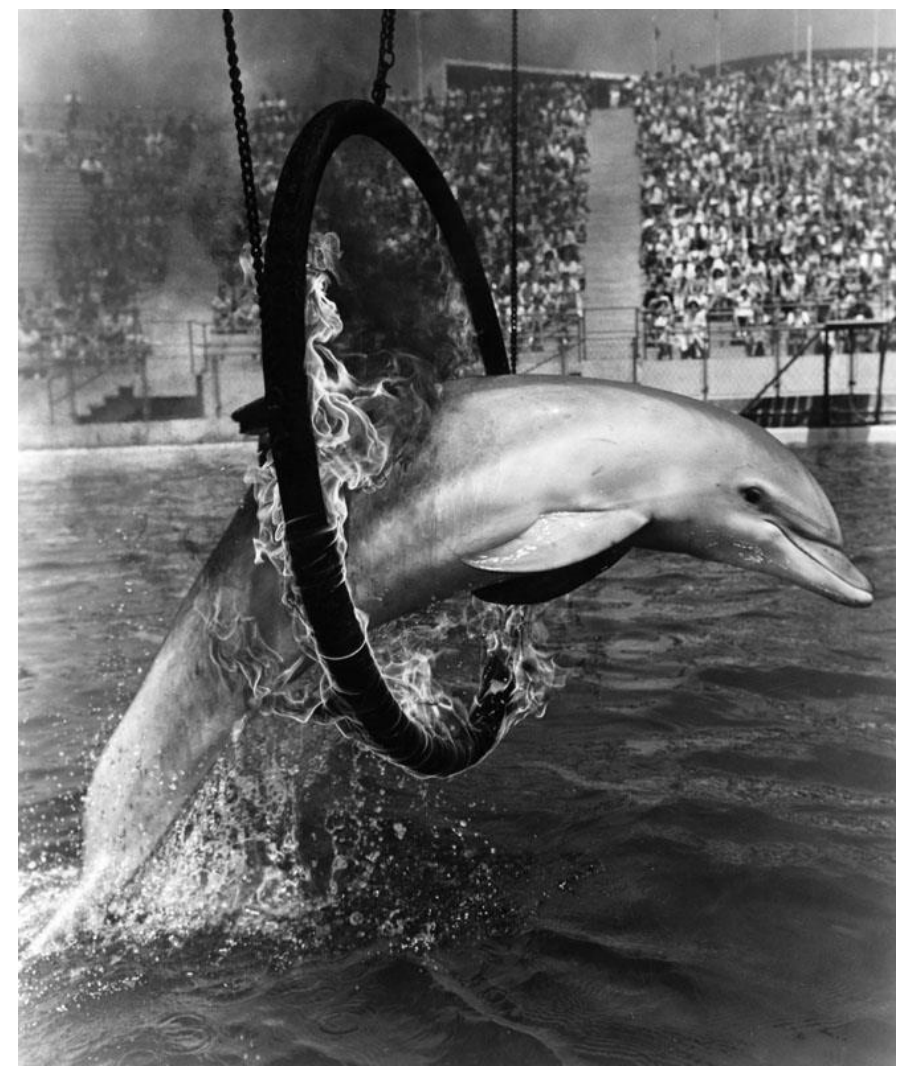

Figure 13. Splash leaps through a flaming hoop during a Marineland show. ${ }^{76}$

While the entertainment potential of exhibiting the larger pilot whales was immense, curators were unsure of how long the species would survive in captivity, and initially staff were unsure whether the species could be trained to perform complex show routines. So Marineland doubled down on reliable dolphin entertainment. By early 1958,

${ }^{76}$ Splash at Marineland. Security Pacific National Bank Collection, Los Angeles Public Library. 
the Sea Arena amphitheater with a 500,000-gallon dolphin pool was nearing completion. Because management intended for the new addition to showcase bottlenose dolphin acts, trainers needed reserve animals in the event that something happened to the four originally from Marine Studios (whose names, sometime during their first year at Marineland, changed to Zippy, Splash, Smiley, and Spray). Despite having captured pilot whales, Norris and the capture team had yet to come up with a reliable technique of acquiring Pacific Tursiops that could provide backup for the new routines. In April 1958, Norris sent his assistant curator John Prescott with the collections team on a return trip to San Diego Bay. This time, Brocato was armed with a new plan: to set a net at the tip of Coronado's North Island parallel to the beach, well ahead of a traveling school. On earlier trips, Norris and Brocato had noticed that the resident dolphins had a daily routine, each day swimming close to the beach along Coronado's north shore. When the team sighted Old Scarback's school again that April, they set the net ahead of the group, and the dolphins entered the trap perfectly. Although the collectors successfully brought four dolphins aboard, Old Scarback—who rushed the net and became enmeshed—-drowned during the operation. ${ }^{77}$ For the second time, the net method ended with a dolphin fatality.

${ }^{77}$ Norris and Prescott, Observations on Pacific Cetaceans of Californian and Mexican Waters, 63:317; Norris, The Porpoise Watcher: A Naturalist's Experiences with Porpoises and Whales, 67-68. 


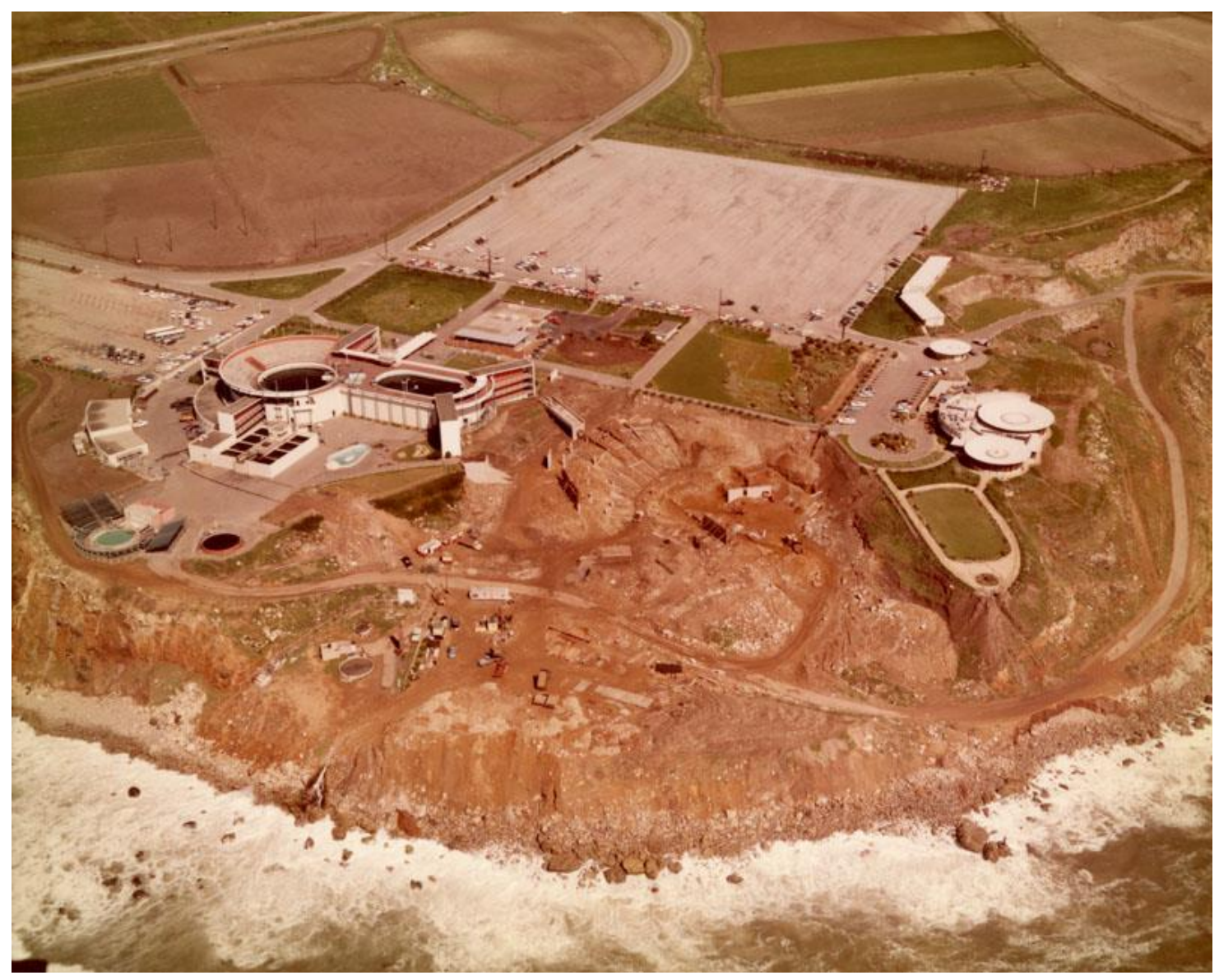

Figure 14. Aerial photograph of Marineland showing the construction of the Sea Arena (center). ${ }^{78}$

On July 8, 1958, the $\$ 500,000$ Sea Arena opened, and staff transferred the Atlantic bottlenose foursome to the new tank. ${ }^{79}$ The pilot whales Bubbles and Squirt were moved to the circular arena tank to be displayed together with the Pacific white-sided dolphins. The Palos Verdes News reported that Zippy, Splash, Smiley, and Spray "will be joined in the future by three additional porpoises in an expanded show" featuring "several new sensational tricks and games." ${ }^{80}$ Although the collecting crew had managed to

\footnotetext{
${ }^{78}$ View of Marineland. Security Pacific National Bank Collection, Los Angeles Public Library.

79 "Marineland of Pacific Opens New Sea Arena," Palos Verdes News, July 10, 1958, 1.

80 "Marineland of Pacific Opens New Sea Arena," 1.
} 
capture another four Pacific bottlenose dolphins in the San Diego Bay (as well as a few other offshore Tursiops in the Catalina Channel), Marineland was evidently in need of more bottlenose dolphins in 1959, when a shipment of six animals arrived in January from Marine Studios. ${ }^{81}$ In the absence of institutional health records, it is unclear what happened to the captured Pacific bottlenose dolphins intended for the Sea Arena show. What is apparent from published sources, however, is that dolphin mortality in 1959 was high. One offshore Pacific bottlenose captured in February 1958, who performed in the Sea Arena shows, died a year later after refusing food for two weeks. One of the original female Atlantic bottlenose dolphins shipped from Florida in 1954 was euthanized in July 1959 after appetite loss left her "so weak," curator David Brown wrote, "that she had difficulty remaining at the surface of the water to breathe." A necropsy later revealed a longstanding infection of the liver by the trematode worm Zalophotrema hepaticum. Deadlier than illness or parasites was the persistent problem of animals swallowing indigestible foreign materials like wood chips, rubber balls, or rocks. Seven cotton gloves were found in stomach of a Lagenorhynchus that staff found dead at the bottom of the tank in July $1959 .{ }^{82}$

The collections team's success in capturing pilot whales allowed Marineland to use whales to barter with Marine Studios for Atlantic bottlenose dolphins. The shipment of six Atlantic Tursiops from Florida in 1959 was paid for by a return shipment of two male pilot whales from Marineland of the Pacific that June. ${ }^{83}$ In March 1962, Marineland

\footnotetext{
81 "Whales Are 'Airlifted' to Florida," Palos Verdes News, June 4, 1959, 1.

82 David H. Brown et al., "Health Problems of Captive Dolphins and Seals," Journal of the American Veterinary Medical Association 137, no. 9 (November 1, 1960): 534-37.

83 "Whales Are 'Airlifted' to Florida," 1.
} 
sent another two whales to Florida in exchange for another six dolphins. ${ }^{84}$ Because coastal Atlantic bottlenose dolphins lived in shallow water along the Gulf states, oceanarium collectors found them to be more economical to capture than the Pacific variety. ${ }^{85}$ Even the U.S. Navy's Marine Mammal Program (NMMP), which began research on dolphins at Point Mugu, California in 1963, opted to fly dolphins in from Florida and Mississippi rather than capture dolphins themselves from local waters. ${ }^{86}$ The NMMP's first veterinarian Sam Ridgway remarked on dolphin acquisition in the early 1960s:

We went all the way across the continent to get dolphins, ignoring the thousands of white-sided and common dolphins just off Point Mugu because the hardy Atlantic bottlenosed dolphins were easier to keep in captivity. In the deep Pacific waters no one had yet been able to catch bottlenosed dolphins consistently. Fishermen in Florida, however, could catch dolphins in shallow bays, channels, inland waterways, and even creeks and rivers. These fishermen used large seines with which they could capture a whole group of animals at once. ${ }^{87}$

A report detailing Marineland cetacean capture records from 1966 to 1973, compiled by Los Angeles Natural History Museum mammal researcher William A. Walker, showed that collections staff took only 18 Pacific Tursiops during that period, compared with 51 Pacific white-sided dolphins. Also, Pacific bottlenose were more likely to die during capture. After being brought aboard the collecting vessel, Walker wrote: "this cetacean is

\footnotetext{
84 “What Makes Salty Smile?," Los Angeles Times, December 2, 1962, sec. TW, 24.

${ }^{85}$ In an effort to reduce to high cost of transporting dolphins cross-country by air, Marineland also experimented with shipping animals by car. In 1960, two local animal trainers transported an Atlantic bottlenose dolphin purchased from the Florida Gulfarium 2,000 miles in the back of a station wagon. At the end of the 43 hour trip, the Palos Verdes News reported that once placed in the holding tank, "the newcomer quickly made friends with the porpoise[s] and was soon eating food." "Florida to Marineland Journey for Dolphin," Palos Verdes News, April 7, 1960, 3. ${ }^{86}$ Sam H. Ridgway, The Dolphin Doctor: A Pioneering Veterinarian Remembers the Extraordinary Dolphin That Inspired His Career (Dublin, New Hampshire: Yankee Books, 1987), 40, 56, 66.

${ }^{87}$ Ridgway, 56.
} 
prone to regurgitate its stomach contents... some of the animals have suffocated due to occlusion of the respiratory passageways with regurgitated food." He estimated capture mortality rates to be "as high as two out of five animals taken." Furthermore, only five of the 18 Pacific Tursiops taken during the period had survived as of the March 1974 data collection date. ${ }^{88}$ The difficulty of capture and low survivability rates made Pacific Tursiops ill-suited for life in captivity, so Marineland found it more economical to import the hardy Atlantic bottlenose instead. ${ }^{89}$

${ }^{88}$ William A. Walker, "Review of the Live-Capture Fishery for Small Cetaceans Taken in Southern California Waters for Public Display, 1966-73," Journal of the Fisheries Research Board of Canada 32, no. 7 (1975): 1202-5.

${ }^{89}$ Some contemporary cetacean researchers who worked with Atlantic bottlenose dolphins believed that the coastal populations of the species adapted more readily to aquarium tanks because they were already accustomed to living in shallow water. John C. Lilly claimed that "deep-sea varieties of dolphins... are used to living in deep water and do not survive captivity in very small enclosures quite as well as Tursiops truncatus." John C. Lilly, Man and Dolphin: Adventures on a New Scientific Frontier (Garden City, New York: Doubleday \& Company, Inc., 1961), 24. 


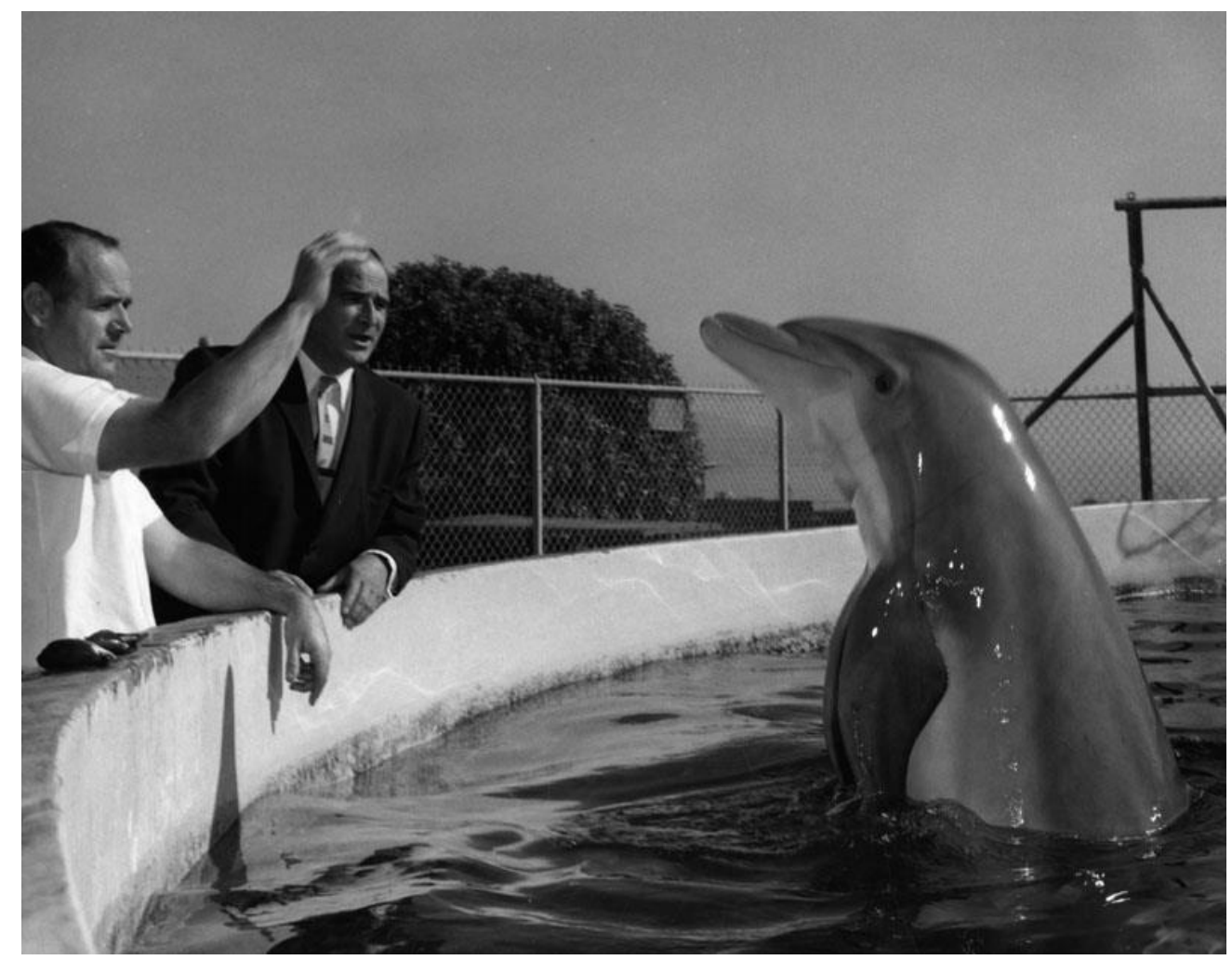

Figure 15. Curator Ken Norris (left) feeds one of Marineland's Atlantic bottlenose dolphins, $1960 .{ }^{90}$

The small number of Pacific bottlenose dolphins in captivity at Marineland reflected a national trend in North American aquaria; a 1976 captive cetacean census revealed that only thirteen Pacific Tursiops in captivity in the U.S. and Canada, compared to 273 Atlantic Tursiops. Despite Marineland's reasonably successful operations in San Diego Bay and in the Catalina Channel, the park opted to import Atlantic bottlenose dolphins and focus on capturing Pacific white-sided dolphins, pilot whales, and to a lesser extent, common dolphins. Across North America, the Atlantic bottlenose dolphin continued to dominate as the premier oceanarium cetacean following the passage of the

\footnotetext{
${ }^{90}$ Ralph Morris, Porpoise Show at Marineland, 1960. Ralph Morris Collection, Los Angeles Public Library.
} 
Marine Mammal Protection Act in 1972. ${ }^{91}$ As early experiences at Marineland of the Pacific had shown, not all dolphin species responded favorably to capture and captivity. The tractable and hardy Atlantic bottlenose dolphin was the industry's species of choice for reliable entertainment.

\section{Caring for Dolphins and Curating the Dolphin's Public Image}

Marineland's early experiences with dolphin captivity were an important part of the transformation in public perceptions of a virtually unknown and under-researched cetacean taking place in the 1950s. Yet during this period, dolphin husbandry practices at Marine Studios and at Marineland — still the only oceanariums in existence in 1954were decidedly experimental and dolphin life-expectancy was low. Marineland collectors devised new methods of capturing cetaceans through experimentation, and similarly, the park's curators developed methods of dolphin veterinary care, management, and training through trial and error. The quality of husbandry improved as Marineland's curators gained experience treating and caring for their animals, but they faced numerous difficulties that the park often hid from public view. In the late 1950s, dolphin exhibits began to pop up across the U.S. and the species soon possessed a carefully crafted Hollywood image that aligned with postwar social values. ${ }^{92}$ From its opening, Marineland camouflaged many of the dolphins' less than socially acceptable behaviors by portraying the animal as a jolly, amiable, and harmless creature that sought human

\footnotetext{
${ }^{91}$ Comparatively, the cetacean with the second highest captive population in the 1976 census was the killer whale (Orcinus orca), with 17 animals represented. Lanny H. Cornell and Edward D. Asper, "A Census of Captive Marine Mammals in North America,” International Zoo Yearbook 18, no. 1 (1978): 221.

${ }^{92}$ Mitman, Reel Nature: America's Romance with Wildlife on Film, 157-79.
} 
company and affection. Advertisements, children's stories, and staff interviews with the popular press protected the wholesome reputation of their most important commercial asset. But behind the scenes, the development of dolphin husbandry at Marineland was often compromised by unforeseen difficulties.

The care of dolphins at Marine Studios revealed early on that aggression between dolphins could become a significant husbandry problem. Arthur McBride described how in 1938 a dominant female relentlessly attacked two juveniles placed in the exhibition tank until the pair died from bite wounds. ${ }^{93}$ When McBride introduced adult males to the tank, he observed that "a stable hierarchy of dominance, closely related to size," took form. Even so, an established dominance order did not always prevent aggression, especially during periods of increased sexual activity. In one instance, McBride fed a dominant male a fish laced with the sedative paraldehyde to prevent him from attacking a recently born calf. ${ }^{94}$ While Marine Studios researchers reported on dolphin aggression in scientific publications, writings for popular consumption took a different tone. In a 1952 Natural History article, the Marine Studios' researcher Frank Essapian assured readers that such "outbursts of anger" by the dominant bulls "are never of a serious nature." 95

As Marineland began its porpoise enterprise, an early experience with aggression led to an institutional policy of keeping male Atlantic bottlenose dolphins separate from the males of other dolphin species. In March 1955, Norris and Brown noticed that one of the Floridian bottlenose males was attempting to mate with a female Pacific white-sided

\footnotetext{
${ }^{93}$ Arthur F. McBride, "Meet Mister Porpoise," Natural History 45, no. 1 (January 1940): 23.

${ }^{94}$ Arthur F. McBride and D.O. Hebb, "Behavior of the Captive Bottle-Nose Dolphin, Tursiops Truncatus," Journal of Comparative and Physiological Psychology 41 (1948): 114-16; Hill, Window in the Sea, 128.

${ }^{95}$ Frank S. Essapian, "The Birth and Growth of a Porpoise," Natural History, 1953, 399.
} 
dolphin also kept in the tank. Interspecies mating among dolphins was a common occurrence in captivity, but a male Pacific white-sided dolphin that also shared the tank reacted by "violently" pushing the other male away. Later that May the male Lagenorhynchus died, curators claimed, "from shock induced by the attacks of captive male Tursiops truncatus," leading staff to henceforth keep the males of different dolphin species separated. ${ }^{96}$ But the public received a somewhat reversed account of how the park's husbandry rule came into being. In his 1960 book Marineland Diver, staff diver Jake Jacobs wrote:

When Frank Brocato brought in some Pacific white-sided dolphins, they lived in harmony with their Atlantic cousins because we took the precaution of putting only the females into the round tank. Zippy and Smiley regarded all females as theirs alone and would probably have made short work of any wild male intruders. ${ }^{97}$

Unlike Jacobs' retelling, curators initiated the separation policy after the bottlenose males had already killed the recently acquired male. And when dolphin aggression affected other species in the tank, Jacobs cast this behavior as defensive. Dolphins in the circular tank attacked and occasionally killed bottom dwelling leopard sharks (Triakis semifasciata) that inhabited the tank floor. ${ }^{98}$ Jacobs interpreted this behavior as symbolic of dolphins" innate "protective instinct toward their young," and therefore "amply justified because the large hunting sharks eat baby porpoises." 99 Although aggression was

\footnotetext{
${ }^{96}$ Norris and Brown, “Observations of Captive and Wild Cetaceans," 316-17.

97 Jake Jacobs, Marineland Diver (New York: Dodd, Mead \& Company, 1960), 147.

${ }^{98}$ Norris and Brown, "Observations of Captive and Wild Cetaceans," 321; Kenneth S. Norris, "Aggressive Behavior in Cetacea," in Aggression and Defense: Neural Mechanisms and Social Patterns: Proceedings of Fifth Conference on Brain Function, ed. Carmine D. Clemente and Donald B. Lindsley, UCLA Forum in Medical Sciences 7 (University of California Press, 1967), 236.

${ }^{99}$ Jacobs, Marineland Diver, 146. Gregg Mitman discusses how Marine Studios similarly depicted dolphin aggression as "defense against adversaries." Mitman, Reel Nature: America's Romance with Wildlife on Film, 170.
} 
a husbandry issue for caretakers and staff, for mass audiences Marineland presented dolphin aggression as defensive or avoided discussing it altogether.

After newly captured dolphins arrived at Marineland, Norris and Brown encountered another husbandry threat: starvation. Curators found that Common dolphins could not be housed with the larger and more dominant Lagenorhynchus or Tursiops because they aggressively outcompeted the more timid species during feeding times. Some Pacific white-sided dolphins procured during the park's early years would resist all attempts by staff to get them to eat and died from starvation in seven to ten days if attempts by staff (usually injections of B-vitamins) proved unsuccessful. ${ }^{100}$ In a 1957 article for Natural History, Norris described the challenge of getting newly captured dolphins to take food from humans as part of the transitional process from the wild to captivity, but declined to reveal that these attempts sometimes failed. "Newly-captured striped dolphins must be taught to eat," but "after a day or two, the new arrival is generally tame enough to swim to the edge of the tank and take food from the feeder's hand," Norris explained. ${ }^{101}$ Starvation may have caused some new animals to die, but for popular consumption, curators cast this struggle as a tender learning process that dolphins quickly adjusted to within a few days.

\footnotetext{
${ }^{100}$ Norris and Brown, "Observations of Captive and Wild Cetaceans," 316, 318; Brown et al., "Health Problems of Captive Dolphins and Seals," 536. The first edition of The Merck Veterinary Manual recommends B-vitamin supplements as a treatment for decreased appetite or anorexia. "Appetite," in The Merck Veterinary Manual (Rahway, New Jersey: Merck \& Co., Inc., 1955), 105-6.

${ }^{101}$ Norris, "Collecting for the World's Largest Fishbowl," 161.
} 


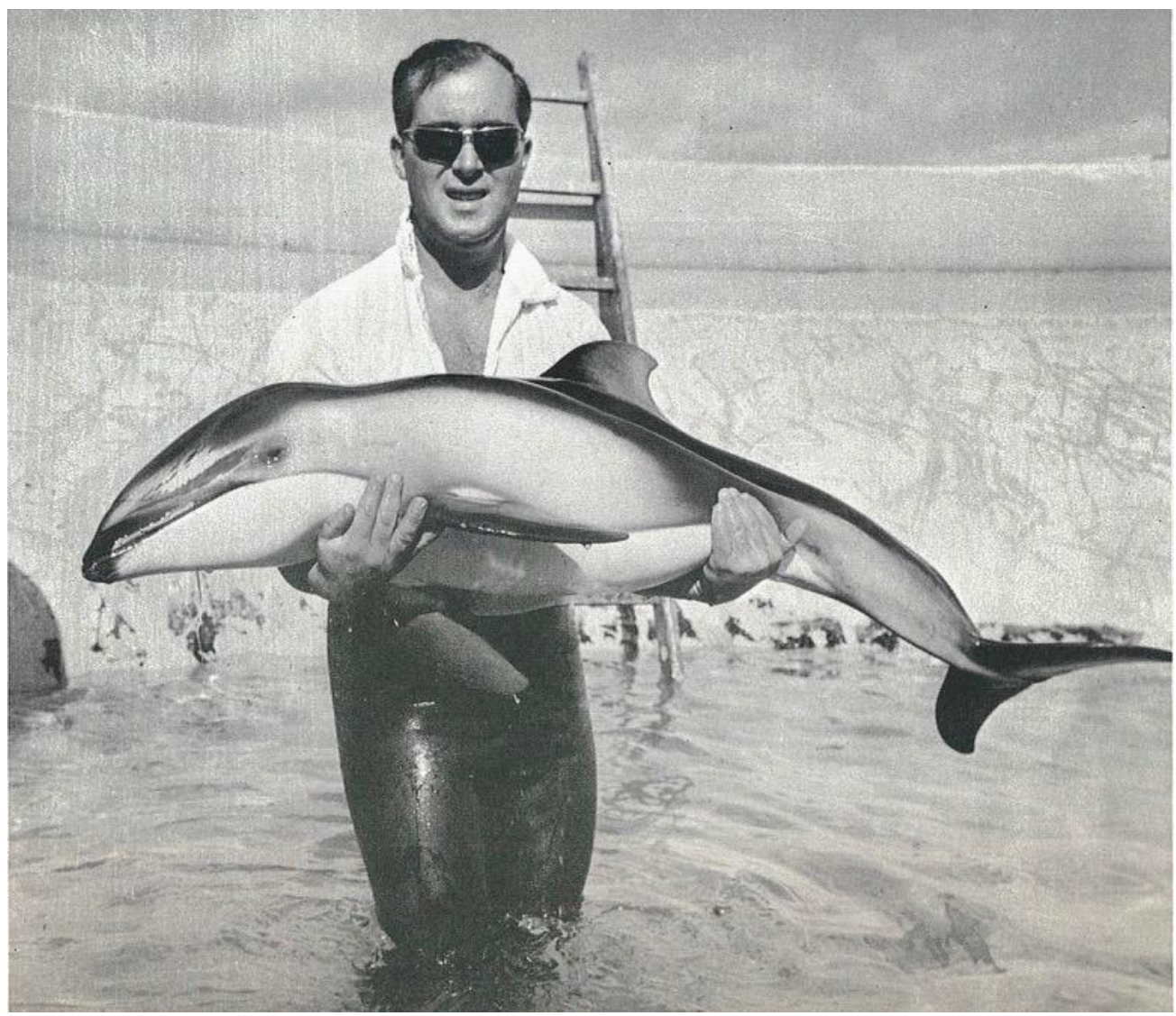

Figure 16. Curator David Brown removes an ailing Pacific white-sided dolphin from the pool to examine it. ${ }^{102}$

Feeding was an important part of the training process, because oceanarium trainers learned early on to use food as a reward for desired behaviors like leaping or retrieving objects. Well-trained dolphins who could replicate complex performance routines became critical to the Marineland's commercial success. But curators noticed that the stress of training and performing five shows a day had consequences that threatened the popular performances. In a talk given at the University of California, San Francisco in 1963, David Brown acknowledged that the entertainment aspect of

102 Jacobs, Jr., Wonders of an Oceanarium: The Story of Marine Life in Captivity, 66. 
Marineland "does expose our animals to stressors which take their toll." Once a dolphin began performing, Brown explained:

After some few months you'll see the effects of stress. We have recovered from these animals typical stress induced disease, such as peptic ulcer, colitis, and so on and so forth. Perhaps the most often occurring problem is the lowering resistance to bacterial infection. ${ }^{103}$

Veterinarians believed gastric ulcers in captive dolphins could be caused by a combination of factors: a diet high in dead fish, which contain high levels of histamine (histamine stimulates gastric acid secretion), anorexia (not eating prevents gastric juices from being neutralized and can cause ulcers), the consumption of foreign objects, and stress. ${ }^{104}$ During a roundtable discussion on captive cetaceans at the First International Symposium on Cetacean Research in 1963, Norris identified stress in cetaceans as the "most severe health problem" caretakers faced, "particularly if they are under severe training." While Norris agreed that stress could come from numerous sources, like improper diet, rough handling, a lack of social interaction, or excessive punishment, he considered performing to be a significant factor: "I think it may result very easily from too much routine, as in shows, where the animals may simply decline." Norris suggested he and his fellow researchers "try to recognize stress when it is at a low-grade level, before it becomes a serious problem." 105 To alleviate stress from "too much show biz," in

\footnotetext{
${ }^{103}$ David H. Brown, "Marvels of Marine Mammals," Noon Topics Lecture, October 23, 1963, Carton 1, Folder 6, UCSF Committee on Arts and Lectures Collection, AR 2015-17. Archives and Special Collections, University of California, San Francisco.

${ }^{104}$ Joseph R. Geraci and Kurt E. Gerstmann, "Relationship of Dietary Histamine to Gastric Ulcers in the Dolphin," Journal of the American Veterinary Medical Association 149, no. 7 (October 1, 1966): 889; J.C. Sweeney and Sam H. Ridgway, "Common Diseases of Small Cetaceans," Journal of the American Veterinary Medical Association 167, no. 7 (October 1, 1975): 536-37.

${ }^{105}$ Kenneth S. Norris, ed., "Round Table: Practical Problems," in Whales, Dolphins, and Porpoises (Berkeley: University of California Press, 1966), 671.
} 
1965 Marineland began rotating show animals (two days on, two days off) and giving dolphins six-month "leaves of absence" in outside holding tanks. ${ }^{106}$

Despite curators' concerns about the stress caused by rigorous performing schedules, Marineland advertisements, visitor pamphlets, and children's stories portrayed the lives of performing dolphins as enjoyable and worry-free. In much of Marineland's early promotional literature, advertisers cast dolphins as "carefree, affectionate...clowns of the sea." ${ }^{107}$ An article in the Lincoln and Mercury Times declared a dolphin's life to be a "continual round of damp foolery" making them "the favorites of young and old." 108 Show routines solidified the dolphin's jolly, clownish image by replicating common circus tricks; the animals put out fires, blew horns, and leapt through flaming hoops. ${ }^{109}$ The picture book Duncan the Dolphin, which documents the life of a Pacific white-sided dolphin from capture to performance at Marineland, depicted dolphin stardom as a rewarding journey achieved through hard work. After acclimating to his new surroundings, Duncan dutifully practices leaps and backflips to please his trainer. Having "learned tricks by working hard," Duncan "can look forward to the pleasures and rewards of performing for as long as he lives." But because he is given food when he performs a trick well, he learns that "work is really play." ${ }^{110}$ Marineland used children's literature as a potent rhetorical space to promote performance as a positive learning experience that dolphins embraced on their own volition. To the contrary, performing was a fact of life

\footnotetext{
${ }^{106}$ Holding tanks held newly captured dolphins, dolphins being trained for shows, or animals held for research purposes. Charles Hillinger, "Marineland: Science Boon," Los Angeles Times, January 24, 1965, E3.

107 "Marineland of the Pacific Full-Page Advertisement," Palos Verdes News, November 4, 1954, 18.

${ }^{108}$ Ronald M. Deutsch, "World's Largest Fishbowl," Lincoln and Mercury Times, April 1956, 18.

109 "Marineland of the Pacific Promotional Brochure."

${ }^{110}$ Lou Jacobs, Jr., Duncan the Dolphin (Chicago: Follett Publishing Company, 1966).
} 
for show dolphins, who received much of their food from positive reinforcement rewards during training sessions and for properly executing show routines.

In the weeks and months that pass, Duncan's days are filled with swimming and playing and leaping. It is fun being a star, hearing people clap when he jumps or takes a bow.

Life at Marineland is good, and Duncan can sleep in the water without a worry to bother him. He has learned the tricks by working hard, and he has come a long way from the day he was captured in a net. He can look forward to the pleasures and rewards of performing for as long as he lives.

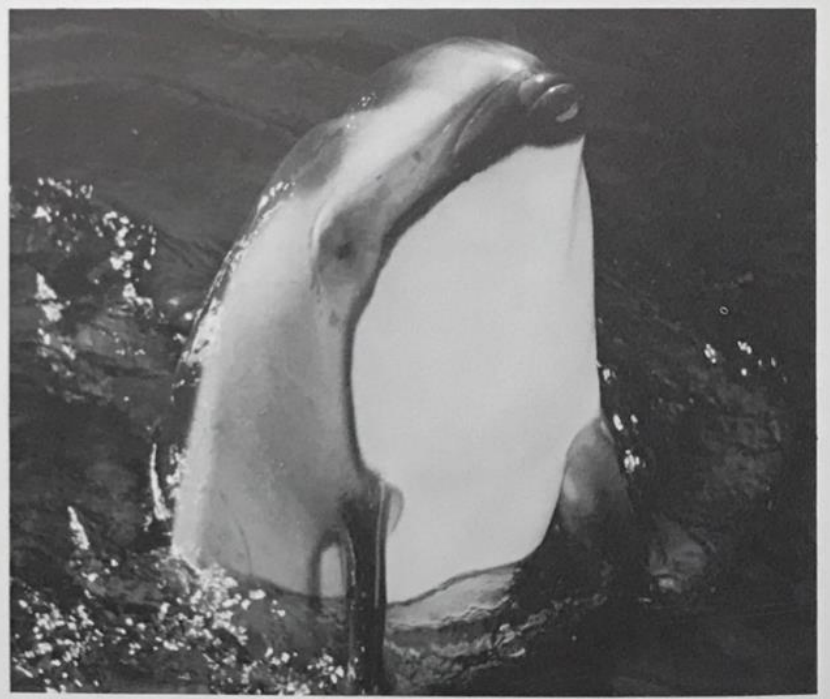

Figure 17. Duncan's hard work at Marineland has paid off; he has become a star. ${ }^{111}$

While public relations staff could leave out descriptions of aggression, starvation, and stress in promotional material, resistance to training and sexual behaviors threatened to tarnish the sanctity of the live dolphin show. To safeguard trainers and audiences from rebellious dolphins, Marineland conducted psychological evaluations of recently captured

${ }^{111}$ Jacobs, Jr., 32. 
animals to ensure that they would respond to training. At a press event in 1956, the Los Angeles Times reported that animal psychologist Keller Breland-a student of behaviorist B.F. Skinner and who had experience training dolphins at Marine Studios—conducted a "pool-side psychoanalysis" of a dolphin named Monte to test him for neuroses. ${ }^{112}$ Most dolphins responded well to training, but in 1962 Marineland returned two female Atlantic bottlenose dolphins to Marine Studios for being “totally bereft of talent." Hollywood writer Vernon Scott reported in his newspaper column that the "old bags," estimated to be 18 to 25 years old, were impossible to train. David Brown, who Scott interviewed for the piece, contended: “They're returning by chartered plane as absolute failures. I did my best to help them with an act... They didn't even try." While Brown joked that "you can't teach an old dolphin new tricks," Marineland's decision reflected the economic reality that oceanariums simply could not afford to care for dolphins that could not perform in shows. ${ }^{113}$ For Marineland, dolphins remained an important commercial asset, but staff preferred dolphins to be younger and free of alleged psychological ailments that might inhibit the training process. ${ }^{114}$

As early as 1948, Arthur McBride had published comments on the sexual conduct of male dolphins held at Marine Studios, who engaged in homosexual behavior and a "good deal" of masturbation, even using a sea turtle as a "sex object." McBride found

\footnotetext{
112 "Porpoise Psychoanalyzed as Penguin Roller Skates," Los Angeles Times, September 27, 1956, B1.

${ }^{113}$ Vernon Scott, "The Hollywood Scene," Eureka Humboldt Standard, March 6, 1962, 4.

${ }^{114}$ Regarding the training process, cetacean scientists Melba and David Caldwell noted: "If an animal is to be trained to do an intricate routine where a long life is especially desirable, then a young animal... is preferable at the start since that animal will have a longer useful life span. On the other hand, older and larger animals are... better for simple display or for simple acts (such as a high jump) that require little training and hence do not mean a large investment in training time and effort, and consequently are more expendable." Melba C. Caldwell and David K. Caldwell, "Behavior of Marine Mammals," in Mammals of the Sea: Biology and Medicine, ed. Sam H. Ridgway (Springfield, Illinois: Charles C Thomas, 1972), 43840.
} 
that males exhibited sexual activity not only during the spring mating season, but "show evidence of sexual excitation all through the year." 115 In his observations of dolphins at Marineland, Norris found that sexual play occurred "nearly every day." In addition to witnessing homosexual activity between males Frankie and Floyd, Norris alleged that the pair "mate[s] with virtually anything and everything that is animate," including other animals in the tank. ${ }^{116}$ According to Norris, sexual behavior of this nature proved an embarrassment for the oceanarium:

[The male dolphins] have attempted mating with skates, bat rays, leopard sharks, green turtles, and even moray eels. It has proved embarrassing to the public to have the big males come to the surface during feeding shows, ignore the routine, and attempt mating with a struggling eel. When a diver descends into the tank he sometimes pets the big dolphins as they cluster curiously about him. Many times this seems to excite the males and erections result. ${ }^{117}$

At Marineland, cetacean scientists Melba and David Caldwell even observed that infant males attempted to copulate with their mothers within a few weeks of birth, and the mothers regularly stimulated the genital region of their male calves. The Caldwells discovered that a dolphin mother and her male young developed a "copulatory pattern" as the calf grew, and at three months of age the male achieved full intromission. Although they believed Atlantic bottlenose dolphins were not sexually mature until age seven, the Caldwells suggested that mother-infant sexual behavior might be a part of a "long learning period for sexual patterns" among dolphins. ${ }^{118}$

\footnotetext{
${ }^{115}$ McBride and Hebb, "Behavior of the Captive Bottle-Nose Dolphin, Tursiops Truncatus," 114-15.

${ }^{116}$ Norris and Brown, "Observations of Captive and Wild Cetaceans," 322.

${ }^{117}$ Norris and Brown, 322.

${ }^{118}$ Caldwell and Caldwell, "Behavior of Marine Mammals," 1972, 424-25.
} 
Sexual play with fellow dolphins, other species in the tank, and from affectionate human contact clashed with the dolphin's family friendly image. Press depictions of dolphin behavior, like the early "Meet Mr. Porpoise" article and Life's 1940 dolphin birth photo essay, continued to center on the intimate bonds between nurturing parents and their calves that reflected a heterosexual family ideal, avoiding any mention of sexual behavior. When a writer for Natural History magazine visited Marineland in 1956 and saw the female Spray carrying a small leopard shark (Triakis semifasciata) from the bottom of the tank to the surface, she took the behavior to be evidence of dolphins' innate desire to care for their babies. In an interview for the piece, Brown observed: "She is treating that shark much as she would her own young, taking him topside to teach him to breathe... a good guess would be that the silly old thing actually imagined the shark to be a baby porpoise. Who knows?"119

Hollywood filmmakers expanded the dolphin's circle of intimacy beyond the species boundary in 1963 in the blockbuster Flipper, which cast the dolphin as a pet-like human companion, a trustworthy sidekick, and vigilant undersea guardian. Set in a small coastal Florida town, the film follows a young boy named Sandy who rescues a wounded dolphin and nurses him back to health in a small fish pen near his home. In the span of an afternoon, Sandy is able to ride the dolphin's fin around the pool—a feat that would have taken months of training with a freshly captured dolphin. Sandy names the dolphin "Flipper" and soon teaches him to perform tricks for neighborhood children. When Sandy's father returns from a long trip, he is displeased, and against his son's wishes, sets Flipper free. Because of his close bond with Sandy, Flipper soon returns to the pen, but

${ }^{119}$ Charlotte B. Norris, “A Porpoise with a Purpose,” Natural History, January 1957, 39. 
eats all of the fish Sandy's father has caught. Angered by the loss, the father instructs Sandy to recoup the lost fish and threatens to kill any dolphin he sees at sea-even Flipper. As the boy ventures out to sea, he is soon joined by Flipper, who helps Sandy catch more fish to please his father. Danger strikes when Sandy is surrounded by sharks, but Flipper fearlessly rams them all to death and carries the injured boy to safety. Moved by the dolphin's heroism, the boy's father vows to treat dolphins with kindness. Sandy's friendship with Flipper, the father muses "led [him] to an understanding of their kind." 120 Like similar midcentury coming of age animal films such as My Friend Flicka (1943), The Yearling (1946), and Old Yeller (1957), an authoritative parent or family member is softened by a male child's formative experience with an animal companion.

According to a Life magazine's story about the filming of Flipper, the dolphin's friendliness was not all Hollywood magic, it extended into real life. Mitzie, the dolphin who played Flipper, proved that "dolphins could challenge dogs as a boy's best friend" if only they could interact with the animals as much as child actor Luke Halpin. And if viewers wished, they could purchase dolphins to have as their own pets: "\$300 each or $\$ 700$ for a pair." ${ }^{121}$ In addition to reinforcing the idea that dolphins possessed pet-like, domestic qualities, Life suggested dolphins could develop special, unique relationships with children. Evoking the archetypal image of the gentle, mild-mannered family dog, "a dolphin who becomes friendly with children seems to prefer them to adults and will take almost any kind of abuse from them," the article declared. ${ }^{122}$ Avoiding any mention of the dolphins' sexual proclivities or potential for aggression, Life's coverage of Flipper

\footnotetext{
${ }^{120}$ James B. Clark, Flipper (Metro-Goldwyn-Mayer, 1963).

121 "My Pal Flipper," Life Magazine, June 7, 1963, 61-63.

122 "My Pal Flipper," 64.
} 
presented the dolphin in its most sanitized form. Although Flipper was not filmed at Marineland of the Pacific, the stereotypes presented in the film solidified the dominant image of the dolphin that would persist at oceanariums nationwide.

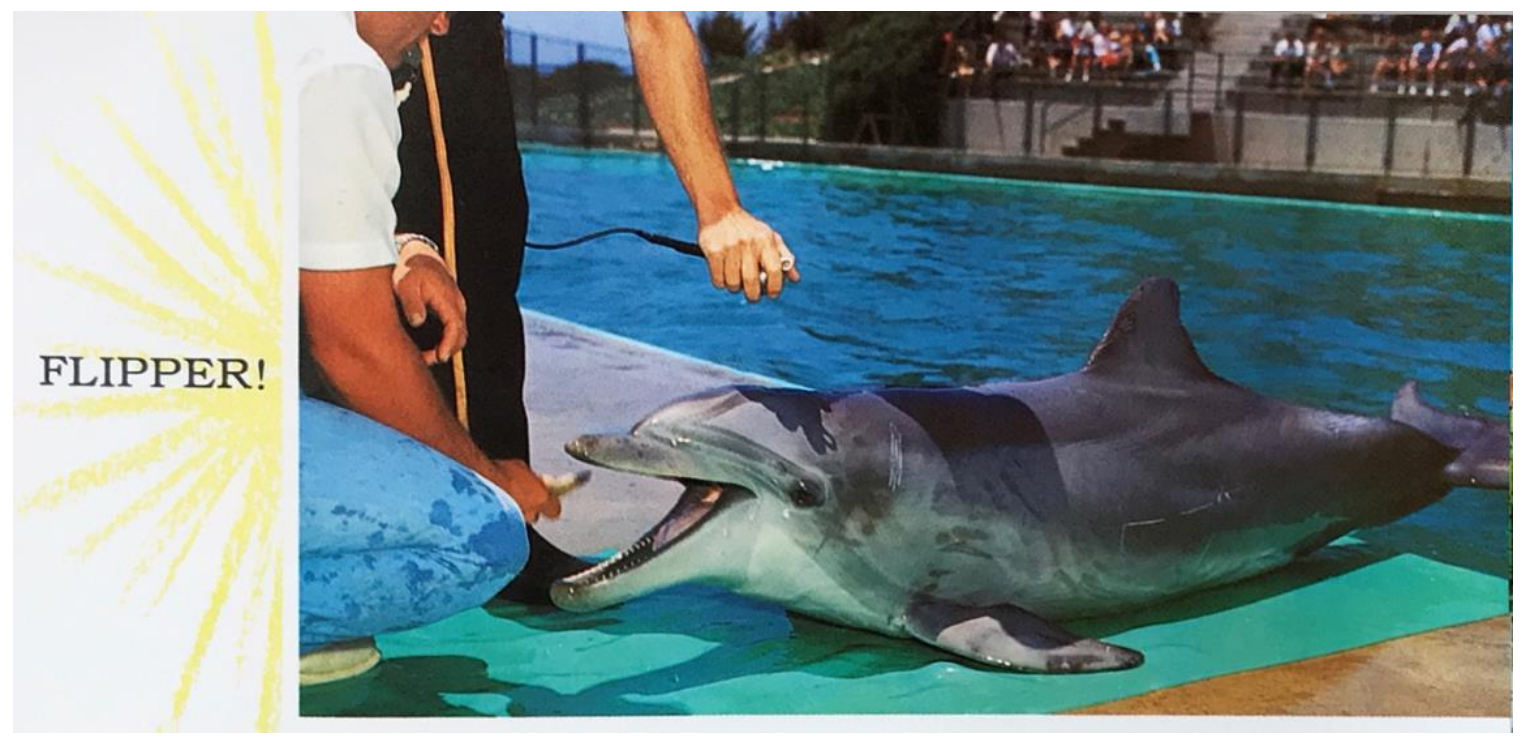

Figure 18. Visitors could meet 'Flipper' at Marineland. ${ }^{123}$

Despite the husbandry issues Marineland staff encountered during the park's early years, discussions of dolphin aggression, sexual behavior, or stress rarely entered public conversation. The Los Angeles Times ran a story on a bottlenose dolphin named Salty who was flown from Marine Studios to Marineland in 1962. Although timid at first, "almost overnight, she forgot her fear" and now enjoys training so much that she "often doesn't want practice to end," the paper declared, going so far as to prevent her trainer from leaving the pool. ${ }^{124}$ Ken Norris' 1974 scientific autobiography The Porpoise Watcher made no mention of dolphin deaths caused by experimental capture methods,

\footnotetext{
${ }^{123}$ Watson, Marineland of the Pacific Souvenir Picture Book, 16. 124 "What Makes Salty Smile?," TW24.
} 
aggression between dolphins, or a lack of veterinary knowledge during his tenure at Marineland, even though he had discussed these issues at length in academic articles he published as curator. Despite attempts to curate public portrayals of dolphin captivity, negative stories of animal deaths and husbandry problems did occasionally receive press coverage. When the University of California Press published the conference proceedings of the First International Symposium on Cetacean Research in 1966, which included a brief discussion of captivity's alleged effects on dolphins, a writer for the Los Angeles Times reported that porpoises "may be suffering from ulcers just like any harried businessman." Observations at places like Marineland of the Pacific led scientists to believe that despite "built-in smiles," "the boredom of living in captivity in a small tank" might be a cause of stress, the paper claimed. ${ }^{125}$ Pointed critiques of captive conditions by journalists, however, remained rare during Marineland's early years.

\section{Conclusion}

As the 1960s progressed, the findings of cetacean researchers nudged the dolphin's public persona further away from the clownish circus performers and pet-like companions featured in marine parks and on film. Research on dolphins was confirming the animals to be highly intelligent, with complex social behaviors and sonic capabilities. Oceanariums facilitated such experiments by providing scientists with much greater access to dolphins in a highly controlled, captive environment. Based on their early observations at Marine Studios, curator Arthur McBride and primate biologist D. O. Hebb hypothesized in 1948 that the dolphin's level of intelligence was somewhere

125 “Porpoises May Get Ulcers in Brooding Over Boredom," Los Angeles Times, April 25, 1966, 3. 
between a dog and a chimpanzee. ${ }^{126}$ By 1961, the neuro-physiologist John C. Lilly had proposed in his popular science book Man and Dolphin that dolphins possess an intelligence on par with humans and that scientists may soon develop a way of communicating with them. ${ }^{127}$ While Lilly's ideas strayed far from the scientific consensus at the time, his theories had a profound effect on the dolphin's public persona.

Marineland made significant contributions to the advancement of dolphin captivity by pioneering the breakaway hoop net method of open ocean collection, which became the industry-wide standard, and by introducing new Pacific dolphin species to captivity. But in the process of developing safer capture techniques, Marineland collectors unintentionally harmed and killed numerous dolphins. Likewise, Marineland curators relied on experimental veterinary care to treat dolphin illnesses, which were often the result of the stress of captivity and the rigor of performance routines. As the public fell in love with dolphins and grew to care for them, Marineland made significant efforts to portray captivity and performance as a pleasant, safe, and enjoyable for the animals themselves. And in promotional literature, the oceanarium cultivated the dolphin's family-friendly image to conform to postwar social values in a deliberate attempt to erase many of the animal's sexual behaviors. However, as the dolphin reached the height of its commercial popularity in North America, Marineland's leading attraction shifted from dolphin shows to pilot whale performances. The spectacle of their massive size caused pilot whales to rapidly eclipse the dolphin as Marineland's marquee animal.

\footnotetext{
${ }^{126}$ McBride and Hebb, "Behavior of the Captive Bottle-Nose Dolphin, Tursiops Truncatus," 122.

${ }^{127}$ Lilly, Man and Dolphin: Adventures on a New Scientific Frontier.
} 
Yet, the difficulties staff encountered with dolphins - aggression, sexual behavior, and husbandry problems - would soon be magnified on a larger scale with the pilot whales. 


\section{Chapter 2}

\section{Staging the Spectacular}

The Capture, Management, and Marketing of the Short-finned Pilot Whale

"Catching a whale had been a sort of growing dream for all of us. It was now far more than a mere job. Over a year in which we had been plotting our attack since the first conference with our Manager, Bill Monahan, it had become a compulsion, something that had to be tried no matter how much idiocy it seemed to involve."

- Kenneth S. Norris ${ }^{1}$

"In the cold, gray dawn of February 28, 1957, I first saw the female pilot whale who was to become our biggest pet, our biggest drawing card, and at times, our biggest problem."

-Jake Jacobs, Diver at Marineland ${ }^{2}$

In March of 1958, the short-finned pilot whale (Globicephala macrorhynchus)

Bubbles made her television debut. The first season of the nationally syndicated program

Sea Hunt, produced by Metro-Goldwyn-Mayer and starring actor Lloyd Bridges as diver

Mike Nelson, featured Marineland's famous captive pilot whale in the episode titled

"Killer Whale."3 At this point, no killer whale (Orcinus orca) had been captured and held in captivity, so Sea Hunt's producers used film of Bubbles to provide close action shots

of the episode's bloodthirsty killer whale. Although pilot whales can reach leng ths of 24 feet and weigh over three tons, these tubular, cigar-shaped dolphins with protruding, bulbous heads are not a particularly menacing species; the curvature of their jaws resembles a fixed smile, and their jaws are lined with seven to nine pairs of small peglike teeth well suited to a diet that consists primarily of squid. ${ }^{4}$ Most importantly, they

\footnotetext{
${ }^{1}$ Kenneth S. Norris, “The Big One Got Away,” Pacific Discovery, September 1958, 3.

${ }^{2}$ Jacobs, Marineland Diver, 159.

${ }^{3}$ Andrew Marton, "Killer Whale," Sea Hunt, March 22, 1958.

${ }^{4}$ Randall R. Reeves et al., "Short-Finned Pilot Whale," in National Audubon Society Guide to Marine Mammals of the World (New York: Alfred A. Knopf, 2002), 444-47.
} 
lack the vivid black and white coloration of the killer whale; pilot whales are dark gray in color, with light gray blaze marks on their chests.
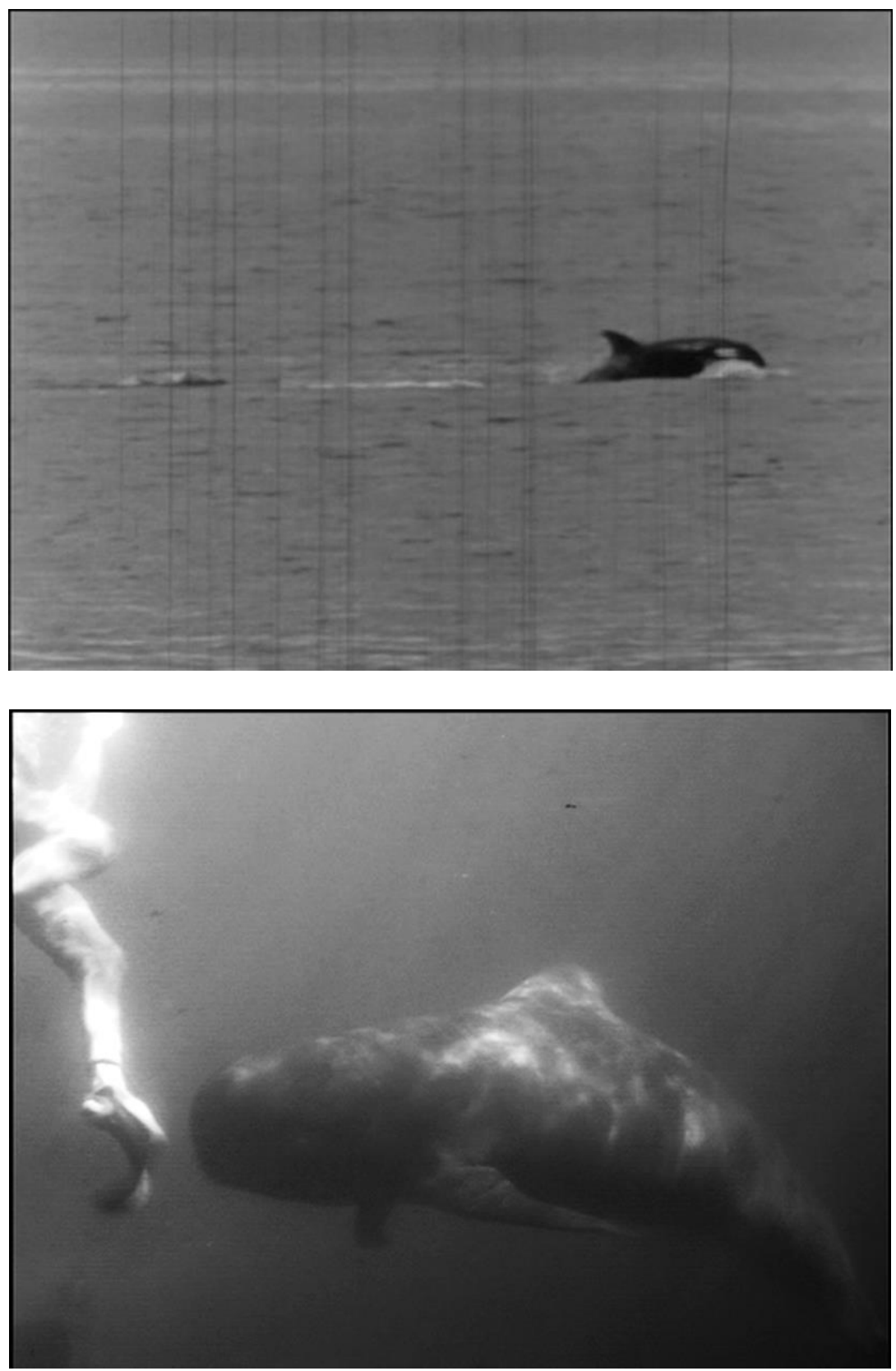

Figure 19. Stills from MGM's Sea Hunt reveal the anatomical differences between a killer whale (above) and a pilot whale (below). ${ }^{5}$

${ }^{5}$ Marton, "Killer Whale." 
To modern eyes familiar with killer whales at oceanariums and on film, the visual differences between the two species are quite evident, and in shots from Sea Hunt, the discrepancy is obvious. To postwar American viewers, however, the sight of a large whale like Bubbles on film signified an unprecedented spectacle of marine animal life. Jacques Costeau's 1956 film The Silent World had shown camera footage of a group of sperm whales (Physeter microcephalus) shot from the Calypso's underwater observation window, but Sea Hunt's up-close portrayal of a pilot whale was more intimate, mysterious, and captivating. ${ }^{6}$ Not only did the television episode indirectly introduce Americans to a species few had seen before, the episode's storyline revealed a great deal about how Americans perceived the animal producers intended for Bubbles to portraythe killer whale. Prior to captivity, mariners and fishermen regarded the killer whale to be a treacherous sea demon capable of more than hunting seals and larger whales: they sought human flesh as well. In Sea Hunt, the killer whale stalks a group of divers and eats one alive. In the stirring final scene, Nelson blasts the beast into smithereens with a wellaimed shot from a harpoon gun.

This chapter, however, does not chronicle the transformation of American perceptions of the killer whale. Before the widespread display of orcas in aquariums across North America in the late 1960s, the pilot whale was the largest performing

\footnotetext{
${ }^{6}$ Jacques-Yves Cousteau, The Silent World (Columbia Pictures, 1956).
} 
cetacean publicly displayed. ${ }^{7}$ The collections team at Marineland of the Pacific had already pioneered the capture of Pacific dolphins. But in February of 1957, Marineland staff returned to the park tugging an inflatable rubber raft with a 12 -foot juvenile female pilot whale nestled inside, making Marineland the first institution to intentionally capture a wild pilot whale for display. She would soon become Bubbles, Marineland's performing sensation, boasting "seventeen hundred pounds of love and affection for her trainer and her fans." 8 As the years went by and the popularity of the whale show increased, Bubbles was joined by a small female named Squirt and a "boyfriend" named Bimbo. By capitalizing on park's popular dolphin shows, the exhibition of pilot whales at Marineland constituted an experiment in animal spectacle and marketing. Promotional material extolled the cheerful whale personalities and circus-like entertainment viewers would see at a pilot whale show.

As with the smaller oceanic dolphins, Marineland collectors employed highly experimental capture techniques and veterinary care methods with pilot whales that involved a great deal of trial and error. The very process of learning to capture the species killed some whales and inadvertently harmed others. Whales often struggled to adapt to their new aquarium environment, and to the surprise of her caretakers, the original

\footnotetext{
${ }^{7}$ The Mito Aquarium in Numazu, Japan is credited with displaying the largest cetacean prior to the capture of killer whales in the 1960s. In the mid-1930s, the Mito Aquarium held a minke whale (Balaenoptera acutorostrata) that survived for nearly three months in an outdoor pool. 1955, the aquarium kept a 20-foot minke for 37 days that escaped by breaking through the nets that connected the pool to the ocean. Minke whales are among the smallest baleen whales, and can grow to lengths of 35 feet. Seiji Kimura and Takahisa Nemoto, "Note on a Minke Whale Kept Alive in Aquarium," Scientific Reports of the Whales Research Institute 11 (1956): 181-84. The first trained whale - and likely the first whale in captivity in North America - was a beluga (Delphinapterus leucas) captured from the Gulf of St. Lawrence and displayed at the Boston Aquarial Gardens in 1861. The whale was trained to pull a woman in a cart around the tank. "Boston Aquarial Gardens," Barre Gazette, June 21, 1861; Jeffries Wyman, "Description of a 'White Fish,' or 'White Whale,' (Beluga Borealiz Lesson.)," Boston Journal of Natural History 7, no. 1 (1863): 603-12.

${ }^{8}$ T.W. Cate, California: World in a Week (United Air Lines, 1964).
} 
Bubbles died in March of 1960 after swallowing a rock from the tank floor. ${ }^{9}$ But pilot whales also presented new challenges Marineland staff had never faced before. Because of their size and strength, pilot whales occasionally endangered or harmed divers who entered the water with them. Their large size also made non-reproductive sexual play and aggression more noticeable to the public, motivating curators to turn to tranquilizers, sedatives, and antidepressants to curtail unwanted behaviors and stave off potential embarrassment. In 1965, newspapers branded the male Bimbo "psychotic" when a doctor consulted by Marineland diagnosed the animal with manic depressive disorder following two years of refusing to perform, weight loss, and "violent, thrashing tantrums" that frightened and even killed other cetaceans in the tank. ${ }^{10}$ Marineland attempted to control Bimbo's behavior by dosing him with psychotropic drugs, but the whale's unpredictable behavior led staff to release him back into the ocean in 1967.

For the most part, the difficulties Marineland staff encountered caring for pilot whales remained hidden from public view. Appearances on television and descriptions in promotional material and advertisements portrayed the whales as genial and tame creatures that thrived in captive conditions. Although Marineland collectors pioneered the methods to capture pilot whales, the park's curators greatly underestimated the difficulty it took to care for animals of their size and misjudged the ability of the whales themselves to assert their agency in a captive setting.

\footnotetext{
${ }^{9}$ The official cause of death, according to a necropsy performed by the Los Angles Livestock Department, was "laryngeal occlusion." David H. Brown, "Further Observations on the Pilot Whale in Captivity," Zoologica: Scientific Contributions of the New York Zoological Society 47, no. 1 (May 9, 1962): 62-63.

${ }^{10}$ Dorothy Townsend, "Sad Saga of Bimbo, the Psychotic Whale," Los Angeles Times, February 7, 1965, I5.
} 


\section{Human-Pilot Whale Interactions Prior to Captive Display}

Even as the agile Pacific white-sided dolphins zipped through the air during a Marineland show, the charismatic pilot whale —if at times slow and unwieldy—put the burgeoning oceanarium Marineland of the Pacific on the map in 1957. What Bubbles lacked in dexterity, she made up for in size. Although pilot whales may have been unfamiliar to many Americans, Bubbles resembled a miniature sperm whale, a species well known to readers as the antagonist in Herman Melville's Moby Dick. Hence, Marineland marketed their star performer 'Bubbles the Whale,' removing the 'pilot' from her name. The pilot whales captured in the late 1950s and 1960s by Marineland were short-finned pilot whales, a common species in the North Pacific. Except for shorter front flippers, their appearance is nearly indistinguishable from their close relative, the longfinned pilot whale (Globicephala melas). The long-finned species prefers the cooler waters of the North Atlantic and the lower Southern Hemisphere. Both species can live upwards of 60 years in the wild. ${ }^{11}$ The name was derived from the way a pilot whale school dutifully follows a leading whale, the 'pilot' - a behavior that allowed hunters to easily drive their large schools to shore. Historically, the largest pilot whale fisheries have existed in the North Atlantic, the Caribbean, Indonesia, and Japan, primarily for meat, blubber, and oil. ${ }^{12}$

Prior to captive display in oceanariums across the United States, Americans-if they knew of the animal at all—considered pilot whale a commodity, chiefly as source of oil. Throughout the nineteenth century, shore whalers along the East Coast of North

\footnotetext{
${ }^{11}$ Reeves et al., National Audubon Society Guide to Marine Mammals of the World, 440-47.

${ }^{12}$ Paula A. Olson, "Pilot Whales: Globicephala Melas and G. Macrorhynchus," Encyclopedia of Marine Mammals (New York: Academic Press, 2009), 851-52.
} 
America corralled passing groups of pilot whales with small boats and drove them to shore where they could easily be slaughtered. ${ }^{13}$ Much like the dolphin fisheries that operated along the coast, whalers rendered pilot whale head and jaw fat into an oil that was used to lubricate fine machinery. ${ }^{14}$ North Pacific whaling fleets, which primarily sought larger baleen and sperm whales for their blubber and oil, rarely pursued pilot whales unless stocks of larger whales grew scarce. "The [oil] yield is small compared to its size," the famed Pacific whaling captain and naturalist Charles Melville Scammon wrote in 1874 , indicating the inefficiency of pursuing pilot whales, which he called "blackfish." Scammon confirmed a more useful aspect of blackfish carcasses when he sampled their flesh. Scammon likened the taste and texture of the meat to "coarse beef" and reasoned that the flavor could be greatly improved if "exposed to the air for a few days, then properly cooked." ${ }^{15}$ If a whaling crew ran out of their terrestrial meat supply during a long voyage, pilot whales could provide a ready and comparable substitute.

In the 1930s, local fishermen from the Caribbean island of St. Vincent established a productive pilot whale drive fishery at the port of Barrouallie, using techniques learned aboard American whaling vessels that often stopped on the island for provisions. St. Vincent whalers primarily hunted the whales for their meat, which was cut into strips, salted, and dried to produce "island bacon." Whale meat, purchased primarily by small

\footnotetext{
${ }^{13}$ Clark, "The Blackfish and Porpoise Fisheries"; Mitchell, "Porpoise, Dolphin and Small Whale Fisheries of the World: Status and Problems," 78.

${ }^{14}$ Lewkowitsch, "Dolphin Oil, Blackfish Oil"; Gilmore, "The Whaling Industry: Whales, Dolphins, and Porpoises," 703.

${ }^{15}$ Charles M. Scammon, The Marine Mammals of the North-Western Coast of North America (San Francisco: John H. Carmany and Company, 1874), 87.
} 
farmers and agricultural laborers, supplemented their starchy diet of cassava, yams, and plantains with much needed protein. ${ }^{16}$

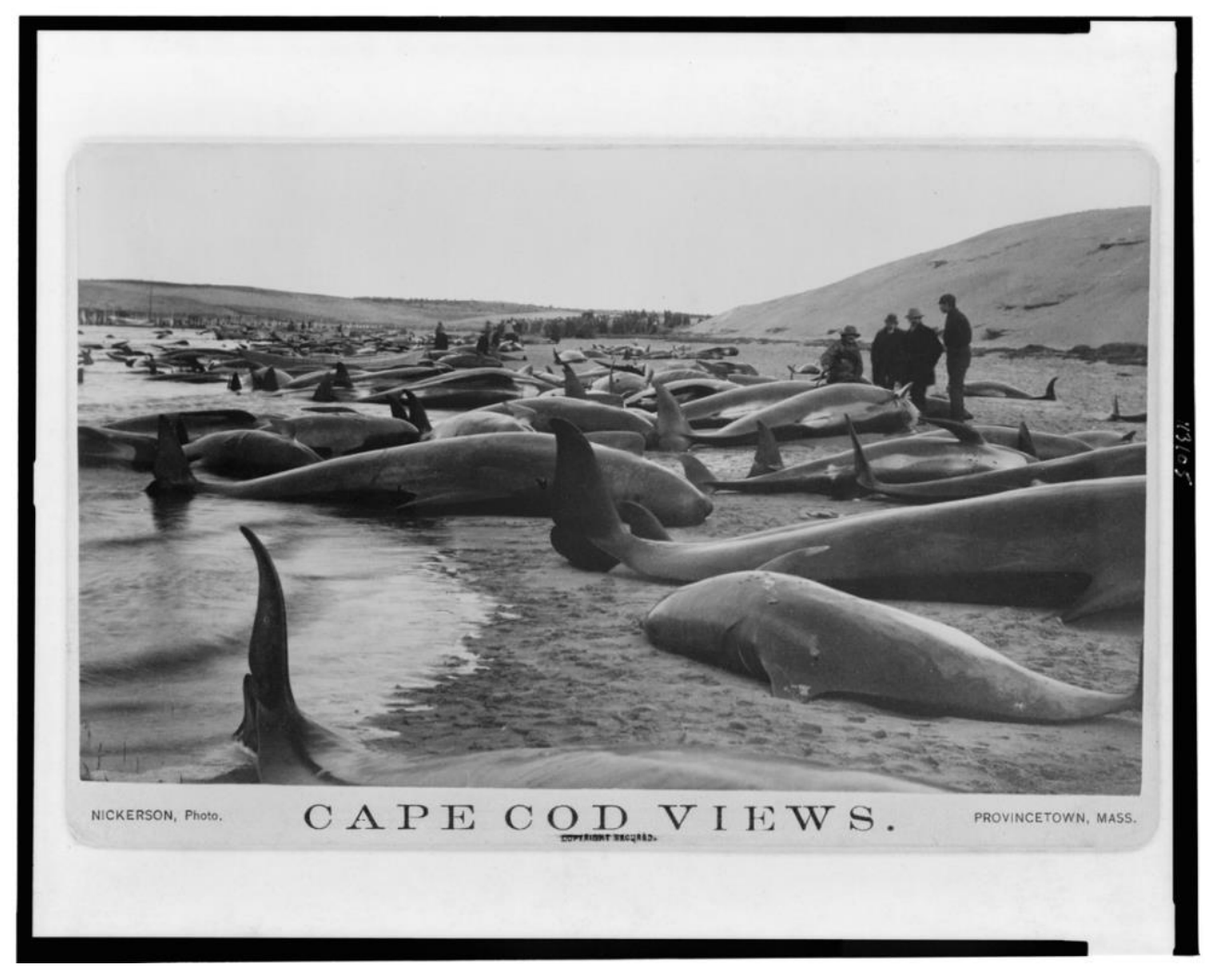

Figure 20. Slaughtered pilot whales on a beach in Cape Cod, c. $1885 .{ }^{17}$

Along the eastern coast of North America, pilot whale fisheries operated well into the postwar period. In 1954, Natural History magazine introduced the pilot whale as a lucrative commodity with "the finest grade of oil on the market." ${ }^{18}$ However, shrinking

\footnotetext{
${ }^{16}$ W.F. Rathjen and J.R. Sullivan, "West Indies Whaling," Sea Frontiers, June 1970, 130-37; John E. Adams, "Shore Whaling in St. Vincent Island, West Indies," Caribbean Quarterly 19, no. 4 (December 1973): 42-50; Mitchell, "Porpoise, Dolphin and Small Whale Fisheries of the World: Status and Problems," 82.

${ }^{17}$ Chase and Capture of Blackfish, 1885. Prints and Photographs Division, Library of Congress, Washington, D.C. https://www.loc.gov/item/95502693/.

${ }^{18}$ Lynwood Chace, "Blackfish Bonanza," Natural History, January 1954, 38.
} 
demand for animal oils forced several fisheries in Newfoundland and Labrador to begin selling pilot whale meat, which they froze and shipped throughout the U.S. and Canada, as an additive to livestock feed. ${ }^{19}$ Overexploitation by Canadian fisheries in the North Atlantic during the 1950 s and 1960 s - with an average of 4,280 whales caught per yearled to a stock collapse that decimated the fishery. ${ }^{20}$ Prior to captive display, commodities produced by North American pilot whale fisheries reinforced the species' role as a valuable economic resource.

\section{Capturing a Pilot Whale}

Marineland managers and staff had entertained the prospect of capturing a live whale - or as Life magazine reported, an animal "to go with [the park's] size" — since early in 1956, because pilot whales, founding curator Kenneth S. Norris believed, "were of a small enough size that capture seemed feasible." ${ }^{21}$ When discussing the possibility with general manager Bill Monahan, Norris reasoned that no aquariums had whales, and "having one, possibly trained, would unquestionably draw visitors from all over the world." 22 Monahan was "delighted" by the idea that Marineland might soon have a whale to add to its growing collection of marine life. On earlier collecting missions, observations by Norris and Marineland's curator of mammals David H. Brown indicated

\footnotetext{
${ }^{19}$ David E. Sergeant, "Whaling in Newfoundland and Labrador Waters," Norsk Hvalfangst-Tidende 42, no. 12 (1953): 694-95.

${ }^{20}$ Mitchell, "Porpoise, Dolphin and Small Whale Fisheries of the World: Status and Problems," 77-78.

21 "The Mammoth Moving of a Sea Mammal," Life Magazine, April 15, 1957, 75; "Kenneth S. Norris Field Notes," 301.

${ }^{22}$ Norris, The Porpoise Watcher: A Naturalist's Experiences with Porpoises and Whales, 71.
} 
that the species regularly congregated in the Catalina Channel off the Palos Verdes coast during the winter months, making them an ideal target for capture. ${ }^{23}$

Aside from their experience capturing Pacific dolphin species, Norris and chief collector Frank Brocato had little to reference in the way of previous pilot whale captures by other parks. Marineland's sister oceanarium Marine Studios rescued four pilot whales from a mass stranding in October 1948. Three of the whales survived only eight days, but a young male named Herman lived for eight months until the group of male Atlantic bottlenose dolphins (Tursiops truncatus) that shared his tank attacked and severely wounded him. ${ }^{24}$ The Marineland crew previously had success netting Pacific dolphin species with a breakaway hoop net from the bow of the vessel when the animal came to the surface to breathe, so Brocato devised a similar technique for the larger pilot whales; he mounted a 26-foot swordfish plank on the bow of the Geronimo with a basket-like cage on the end. From this "porpoise pulpit," a crewmember could slip a net (attached to a pole and a manila line, like an oversized butterfly net) over the head of an unsuspecting whale. Once the net was secured over the animal's head, the whale would invariably take off with the line attached to the boat. Once the whale was too exhausted to continue struggling, the crew could bring it alongside the boat and inflate a rubber raft beneath it, allowing the animal to be towed to shore. ${ }^{25}$

\footnotetext{
${ }^{23}$ Norris and Brown, "Observations of Captive and Wild Cetaceans," 323-24.

${ }^{24}$ Henry Kritzler, "Observations on the Pilot Whale in Captivity," Journal of Mammalogy 33, no. 3 (August 1952): 321; Hill, Window in the Sea.

25 "Kenneth S. Norris Field Notes," 301. Netting dolphins and whales by the head became the standard method of open ocean capture among American oceanariums, following the tail-grabber device developed by Marine Studios. At the First International Symposium on Cetacean Research (1963) round table discussion among cetologists and oceanarium curators regarding capture techniques, Norris explained: "When you catch an animal by the tail, you automatically pull its tail upward... as the animal has a tendency to dive, it will have difficulty in breathing, and often drowns." The head capture method solved this problem. Norris, "Round Table: Practical Problems," 649-50.
} 
Prior to the widespread captivity of whales and dolphins in aquaria, cetacean scientists primarily collected biological data by analyzing the carcasses of killed or beached animals. ${ }^{26}$ Accordingly, the Marineland team decided they needed to measure a dead whale to ensure that a capture net would fit securely. Initially, pilot whales' tightknit social behavior made this difficult. In December 1956, armed with his deer rifle, Brocato shot two animals, both of which the crew were unable to bring aboard. Norris reported that the first whale, from a group of fifteen found swimming in the San Pedro Channel, was forced underwater and "literally [taken] away from the ship" by other pilot whales in the school after being shot. On a second attempt, Brocato shot a young, seven-foot whale off the western coast of Catalina Island. The body quickly sank, but the crew observed an adult whale repeatedly bringing the younger animal to the surface, holding the juvenile in its jaws. ${ }^{27}$ The Marineland crew redoubled their efforts in February of the next year, and again attempted to procure an animal for measurements. A group was sighted off Ribbon Rock, on the northwestern coast of Catalina, and Brocato took a shot. A larger whale raced over, Norris recounted, and "reared partly out of the water and fell over the blowhole of the stricken beast," which caused the dead animal to sink. In his field notes, Norris reported that entire school "[dove] in search of their member." ${ }^{28}$ Norris would later describe this "cooperative behavior" in an extensive published report on his observations of Pacific cetaceans in 1961, compiled with fellow curator John H. Prescott.

\footnotetext{
${ }^{26}$ For a brief history carcass analysis in the field of cetacean science, see the subsection "Shoot First, Ask Questions Later: Deductions about Behavior from Dead Animals" from Amy Samuels and Peter L. Tyack, "Flukeprints: A History of Studying Cetacean Societies," in Cetacean Societies: Field Studies of Dolphins and Whales, ed. Janet Mann et al. (Chicago: University of Chicago Press, 2000), 20-22.

${ }^{27}$ Norris and Prescott, Observations on Pacific Cetaceans of Californian and Mexican Waters, 63:293-94.

28 "Kenneth S. Norris Field Notes," 301.
} 
The behaviors Norris observed corroborated a growing scientific consensus that whales and dolphins "offer[ed] assistance" when a fellow becomes injured, either by keeping it at the surface to breathe or taking it away from the source of apparent danger. ${ }^{29}$ Ultimately, the crew landed an animal a few days later, on February 5. With two shots, Brocato brought down a male near the same spot off Ribbon Rock, and the team got their measurements. "This procedure sounds cruel and was not pleasant for any of us," Norris recounted in his field notes, "but we could rationalize our way out by remembering the works of whalers past and present, and the fact that the animal would die instantly from a shot in the head." ${ }^{30}$ As for the animal's somewhat peculiar appearance, "The creature looked much like a great overgrown tadpole with a long grotesque tail," Norris remarked. ${ }^{31}$

For the next few weeks, the crew made attempts to capture whales from schools throughout the Catalina Channel, nearly all of which were unsuccessful. Although they could get close to the animals, the whales either slipped out of the net or evaded it entirely. One late afternoon, with the Geronimo cruising off the Catalina Island town of Avalon, first mate Frank Calandrino sighted a group of whales. As the ship edged toward the school, Brocato manned the "porpoise pulpit," and after a few fruitless swings, hooped the net around an animal's head. As the whale dove, the manila line flew off the

\footnotetext{
${ }^{29}$ Norris and Prescott, Observations on Pacific Cetaceans of Californian and Mexican Waters, 63:292-94. Norris' observations provided evidence for emergent hypotheses in the field of cetology regarding epimeletic (caregiving) behavior in cetaceans. Cetologists David K. Caldwell and Melba C. Caldwell presented a paper on the epimeletic behavior in cetaceans at the First International Symposium on Cetacean Research in 1963. For a list of studies on caregiving behaviors documented in delphinids, see David K. Caldwell and Melba C. Caldwell, "Epimeletic (Care-Giving) Behavior in Cetacea," in Whales, Dolphins, and Porpoises, ed. Kenneth S. Norris (Berkeley: University of California Press, 1966), 763-75.

30 "Kenneth S. Norris Field Notes," 301.

31 "Kenneth S. Norris Field Notes," 302-3.
} 
deck; the first dive took nearly 600 feet. By the early morning of the next day, the whale finally tired and was brought alongside the Geronimo. As the animal thrashed and tossed, Boots slipped the raft under the whale, and Brocato gave the signal to release the $\mathrm{CO}_{2}$ from the tanks onboard to inflate it. After the whale was safely tied down inside the raft, the Geronimo chugged towards Marineland, and Norris examined his quarry. "The whale proved to be in excellent shape and breathed very satisfactorily," he recalled. In the course of five-and-a-half hours, Marineland finally had its prize. As the boat arrived at Marineland's pier and staff brought the captive ashore, Norris concluded his field note entry: "the whale went up the hill to her holding tank and into the waiting arms of the public relations department." 32

\footnotetext{
32 "Kenneth S. Norris Field Notes," 307-8. It is worth noting that before public anti-captivity sentiments began to take hold in the North America, methods of capturing cetaceans were guarded by the budding oceanarium industry. At the First International Symposium on Cetacean Research held in 1963, Norris acknowledged that cetacean capture techniques had been "shrouded in corporate secrecy." At a roundtable discussion, he prefaced his comments on capture by stating: "I will not, however, discuss details that I have been asked to withhold." Norris, "Round Table: Practical Problems," 649.
} 


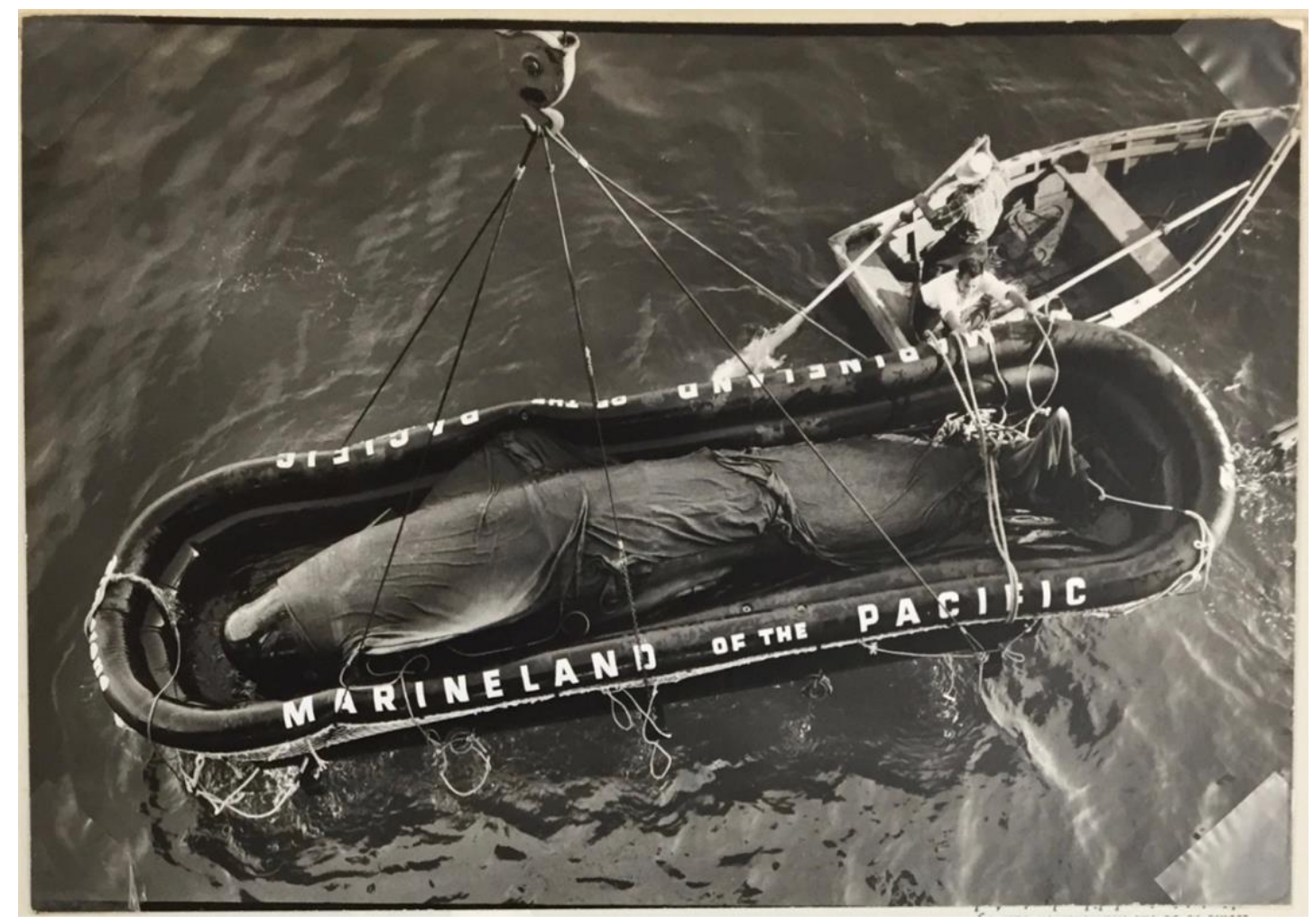

Figure 21. Bubbles arrives at the Marineland pier, $1957 .^{33}$

\section{The Care and Training of Bubbles}

While enthusiastic reporters penned newspaper accounts of the capture,

Marineland's animal caretakers faced the larger problem of ensuring that this new species adjusted to captivity. Staff gave the whale a temporary name-Mabel—and watched as she circled in her small 30-foot in diameter, six-foot-deep holding tank. ${ }^{34}$ She measured 12 feet long and weighed nearly 1,500 pounds. For the next week, Mabel refused the

\footnotetext{
${ }^{33}$ Bubbles arrives, 1957. Box 61, Kenneth S. Norris Papers, University of California Santa Cruz.

${ }^{34}$ Because pilot whales cannot completely submerge themselves in pool that is six feet deep, Marineland later determined that larger pools were needed to acclimate the species to captivity. A 1975 report stated that "shallow pools" (six feet deep) "are not sufficient for acclimating this species of cetacean. Under these conditions, the animals appear depressed and spend extended periods floating on the surface." Walker, "Review of the Live-Capture Fishery for Small Cetaceans Taken in Southern California Waters for Public Display, 1966-73."
} 
squid, mackerel, and anchovies her caretakers offered her, and she became listless and lethargic. Her "reluctance to swim," curator David Brown reported, caused her head, back and dorsal fin to become severely sunburned. The Los Angeles Times quipped that the "sulking" Mabel was "getting all burned up about some enforced sun bathing." Brown applied zinc oxide ointment to the affected areas and decided it would be best to move the whale to a larger tank so she could adequately submerge herself. ${ }^{35}$ Remembering how the pilot whale Herman had been killed by aggressive male dolphins at Marine Studios, Marineland curators decided against moving Mabel into the circular dolphin tank, and opted to place her in the 500,000-gallon oval tank that housed the oceanarium's main fish collection.

Moving Mabel into the large oval tank required staff to hoist her four stories over the top deck. Brown injected the animal with vitamin B1 to stimulate her appetite, and 20-cc. of the steroid Metacorten to act as a "tranquilizer." 36 Veterinarians used Metacorten, also known as the steroid prednisone, to treat ketosis, inflamed joints, or dermatitis in horses and cattle. Veterinary manuals did not list it as a tranquilizer. ${ }^{37}$ Whether the drug calmed Mabel or not, this marked the first time an oceanarium used pharmaceutical drugs to attempt to alleviate the stress caused to a cetacean by moving it. After draining the holding tank, five staff members rolled the whale onto a v-shaped platform (padded with a mattress), loaded the platform onto a truck, and a built-in hoist

\footnotetext{
${ }^{35}$ David H. Brown, "Behavior of a Captive Pacific Pilot Whale," Journal of Mammalogy 41, no. 3 (August 1960): 342-43; "Mabel the Whale Gets Relief from Sunburn in Giant Marineland Pool," Los Angeles Times, March 7, 1957.

${ }^{36}$ Brown, "Behavior of a Captive Pacific Pilot Whale," 343.

${ }^{37}$ Paul G. Stecher, ed., "Prednisone," The Merck Index of Chemicals and Drugs (Rahway, New Jersey: Merck \& Co., Inc., 1960).
} 
on the top deck slowly lifted the creature upwards and into the tank. Through the entire process, the whale was out of the water for only fifteen minutes. Once in the tank Mabel still would not eat, so Brown donned his diving gear, swam out to her, and with the aid of 16-inch metal tongs, pried open the whale's mouth and popped some squid inside. Initially disgruntled by the forced feeding, Mabel snapped her jaws at Brown, which he recognized as a "warning signal" commonly used by bottlenose dolphins. Diver Jake Jacobs lamented that this feeding process was excruciatingly slow, "like feeding an elephant one peanut at time." The next morning though, Mabel began to accept food, consuming over 200 pounds of squid thrown to her from the top deck in the next 72 hours. ${ }^{38}$ Mabel's presence in the display tank did not go unnoticed by local school children, who by a vote named the whale 'Bubbles' instead. ${ }^{39}$

\footnotetext{
${ }^{38}$ Brown, "Behavior of a Captive Pacific Pilot Whale," 343-44; Jacobs, Marineland Diver, 162-63. Anorexia, or the refusal to feed, was common in animals newly introduced to captivity. For veterinary treatments for anorexia, see "Appetite."

${ }^{39}$ Norris, The Porpoise Watcher: A Naturalist's Experiences with Porpoises and Whales, 82.
} 


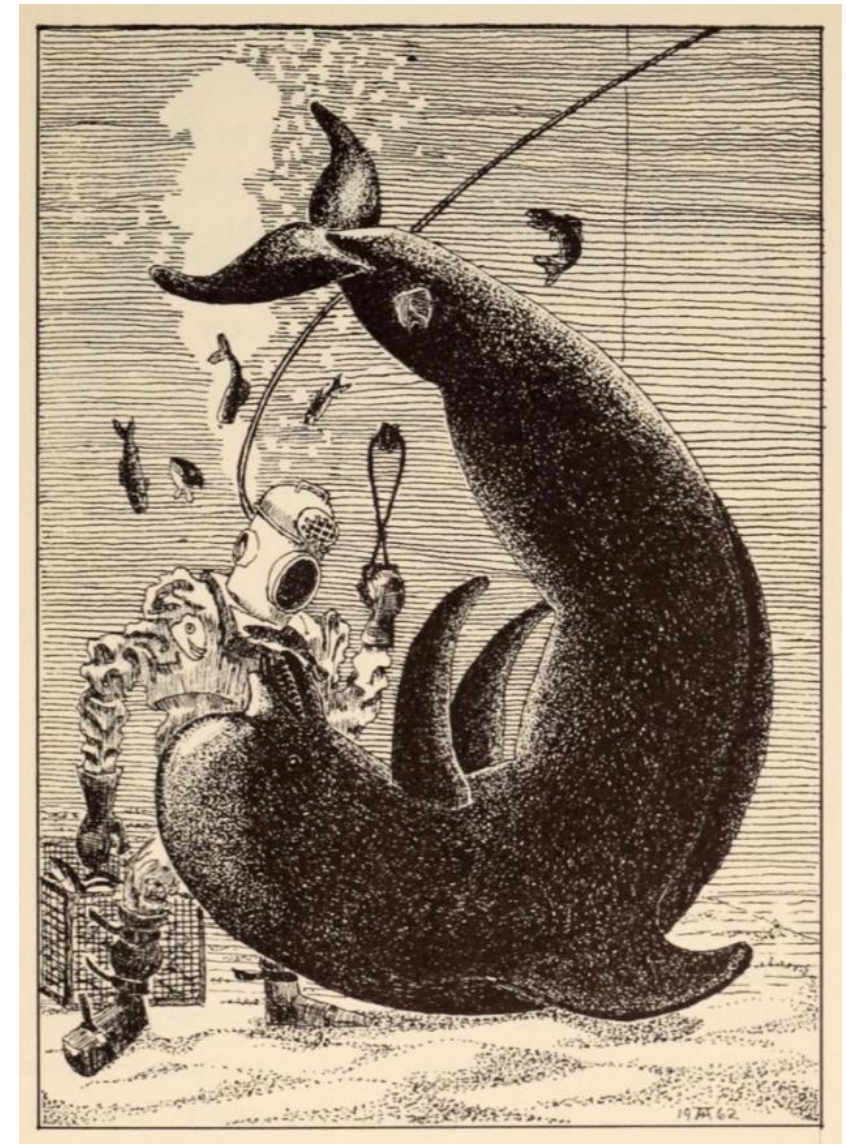

Figure 22. An artist's rendering of Brown feeding Bubbles with tongs. ${ }^{40}$

Now that Bubbles readily accepted food, Marineland caretakers were faced with other problems, specifically, the other species in the tank. Soon, Bubbles learned to swim to a wooden plank to receive food, but other animals in the tank-like the sea turtles and mahi-mahi — were fed at the same location. Brown reported that during feeding times, the presence of these hungry interlopers "seemed to annoy the whale," and Bubbles routinely chased them off. In one instance, Bubbles rammed a small turtle so forcefully that the creature was thrown three feet out of the water and its carapace was shattered. Objects in

${ }^{40}$ Illustration by Richard D. Rice in Henry Chapin, The Remarkable Dolphin \& What Makes Him So (New York: Young Scott Books, 1962), 43. 
the tank also posed problems for Bubbles. Soon, Bubbles was trained to retrieve a rubber inner-tube, which on the morning of June 17, mysteriously went missing. Bubbles refused to feed, and Brown, who suspected she had swallowed something large, administered apomorphine to induce regurgitation and prescribed mineral oil-filled squid to lubricate the apparent blockage in her throat. On the twelfth day, the inner-tube was found floating in the tank, still fully inflated, and she returned to feeding normally. ${ }^{41}$ "No one," chided the Palos Verdes News, "suspected that Bubbles had mistaken [the innertube] for a king-sized doughnut." 42 The tendency for small cetaceans to swallow foreign objects came as no surprise to Brown, as a number of dolphins died at both Marine Studios and Marineland from swallowing toys and debris in their tanks. In the past, Brown successfully used this mineral oil treatment on two dolphins at Marineland, one that swallowed a leather glove, and another that swallowed a wooden ball. ${ }^{43}$

Using techniques Marineland staff had used to train sea lions and dolphins, caretakers initiated "whale-training program" for Bubbles, with the intention of creating a new whale show to entertain oceanarium guests. Marineland curators hoped the same techniques would work with a captive pilot whale. Resident animal trainer Kent Burgess, who would later go on to train the orca Shamu at SeaWorld, cut his teeth training Bubbles at Marineland. ${ }^{44}$ Having already trained Bubbles to swim to a wooden plank to receive food, Burgess gradually encouraged her to jump higher and higher out of the

\footnotetext{
${ }^{41}$ Brown, "Behavior of a Captive Pacific Pilot Whale," 344-45.

42 "Bubbles Gets Whale of a Tummy Ache, Coughs Up Life Ring," Palos Verdes News, July 11, 1957, 7.

${ }^{43}$ Brown, "Behavior of a Captive Pacific Pilot Whale," 345. Veterinarians used apomorphine as both an emetic (to induce vomiting) and an expectorant (to clear mucus in the airways). Paul G. Stecher, ed., "Apomorphine Hydrochloride," The Merck Index of Chemicals and Drugs (Rahway, New Jersey: Merck \& Co., Inc., 1960).

${ }^{44}$ Clarence Rawlings, "Psychology Used in Teaching Whales," Madera Daily News Tribune, October 1, $1959,8$.
} 
water with the use of a modified feeding platform, which could be mechanically raised 15 feet above the tank. After eyeing the position of the food, Bubbles would dive to the tank floor, turn around, and swim toward the plank with "great power," and clear the surface "in a most spectacular manner," Brown described. ${ }^{45}$ With the sound of a whistle and a healthy helping of squid as reward, Marineland trainers used positive reinforcement training to teach Bubbles to shake hands, retrieve a plastic dumbbell, place a "whalesized" hat on her head, and sing for the audience. The animal perfected these tricks to the point that the park put on regular whale shows, often several times a day. ${ }^{46}$

With Bubbles as the star performer, "every day was like Sunday" at Marineland, the diver and caretaker Jake Jacobs remembered. An internal poll of park visitors confirmed that the majority came just to see "the only performing whale in the world" put on a show. Brocato and the collections crew soon captured another pilot whale, a young female the park named Squirt in June of 1957, to ensure the oceanarium's "priceless" attraction might still carry on if something happened to Bubbles. ${ }^{47}$ After 14 months of captivity in the oval fish tank, caretakers began to fear that Bubbles' performing days might soon be over after her interactions with humans gradually began to turn more aggressive. Bubbles had already caused staff consternation after she began eating the kelp bass and Pacific barracuda that shared her tank; frequently, Brown wrote, she "berated" sea turtles and rays to the point that they vomited during feeding times. ${ }^{48}$ But Marineland curators were most alarmed when staff divers became the target of the whale's apparent

\footnotetext{
${ }^{45}$ Brown, "Behavior of a Captive Pacific Pilot Whale," 345-46.

${ }^{46}$ Jacobs, Marineland Diver, 165.

47 Jacobs, 166; "Marineland Gets New Baby Whale," Palos Verdes News, July 3, $1958,1$.

${ }^{48}$ Brown, "Behavior of a Captive Pacific Pilot Whale," 347.
} 
antagonism. Head-butts that staff had initially dismissed as "boisterous love-making," became more dangerous. While diver Ray Cribbs fed fish at the bottom of tank one afternoon, Bubbles butted him with her head, dislodging his diving helmet and knocking him out for a few seconds. Another diver barely escaped injury while swimming on the surface, when Bubbles attempted to ram him against the tank wall. While filming an episode of the BBC's "Danger is My Business" television program that featured Brown training and riding Bubbles around the tank, she "suddenly became furious" and agitated by the film crew's presence, chasing each of the five cameramen out of the water. This pattern of aggressive behavior prevented staff from entering the oval tank for feeding or cleaning; instead, caretakers fed the fish species by dropping down a bucket attached to a line, and the observation windows were soon covered in a thick layer of algae. ${ }^{49}$

Brown believed Bubble's aggressive behavior was caused by her "enforced solitude,' or the lack of other cetaceans in the tank, citing a case in which a dolphin at Marine Studios, kept alone in a holding tank for many months, tried to bite its handlers if they came near the tank. To remedy this issue, in July of 1958 Marineland staff moved Bubbles into the circular arena tank, where she was joined by fellow pilot whale Squirt and two female Pacific white-sided dolphins (Lagenorhynchus obliquidens). Following the transfer out of the fish tank, Bubbles' aggression towards divers ceased, "conceivably because of the company of the other animals" according to Brown. ${ }^{50}$ Bubbles and Squirt "took to each other at once," and trainers soon had Squirt "performing like a veteran." 51

\footnotetext{
${ }^{49}$ Jacobs, Marineland Diver, 168-70.

${ }^{50}$ Brown, "Behavior of a Captive Pacific Pilot Whale," 349.

${ }^{51}$ Jacobs, Marineland Diver, 173.
} 
With Bubbles and Squirt performing for audiences in the whale show five times per day, Marineland staff hoped their whale troubles might be soon over. ${ }^{52}$

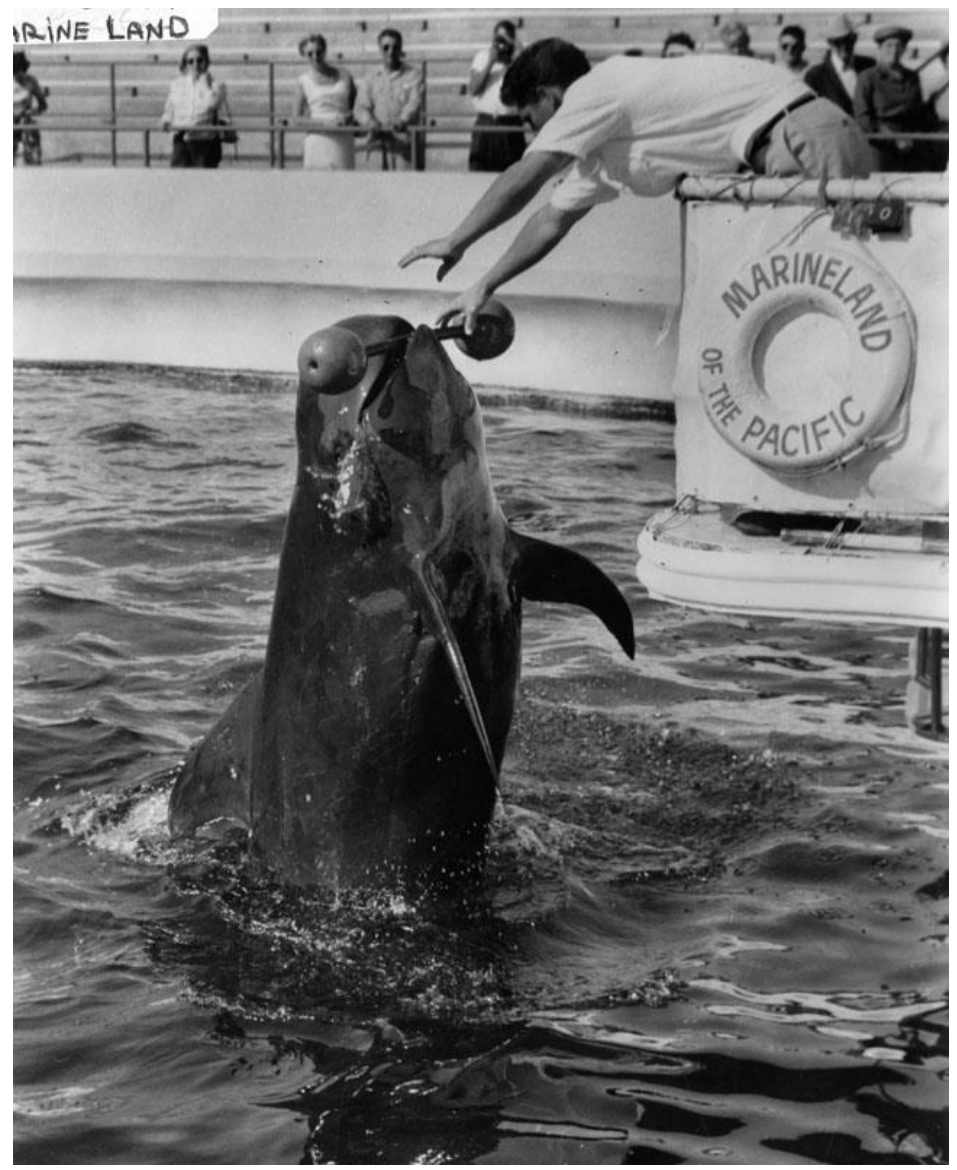

Figure 23. Bubbles performs in a Marineland show. ${ }^{53}$

\section{Captive Pilot Whale Behavior vs. Character Marketing}

Between the successful capture of two pilot whales and an increasingly popular whale show, Marineland collectors, curators, and staff had significant accomplishments

\footnotetext{
${ }^{52}$ Marineland of the Pacific, "Information Sheet and Schedule of Events."

${ }^{53}$ Whale Show at Marineland, October 14, 1959. Security Pacific National Bank Collection, Los Angeles Public Library.
} 
for the oceanarium's public relations team to utilize. Staff interviews with local newspapers emphasized the bravery of Brocato and collecting crew, the excitement of the whale show, and the intelligence and charm of the animals themselves. To promote Marineland's now famous whale spectacle, public relations staff engaged in the construction of a distinct, anthropomorphized whale character-Bubbles-who enjoyed captivity and human companionship, took pleasure in performing for an audience, and could be trained as easily as a household pet. However, the positive whale personality traits expressed in press releases, newspaper columns, and children's literature often contradicted the behaviors of the whales themselves. Not only did Marineland caretakers grapple with bouts of aggression towards humans, they also struggled with animals that refused to perform, suffered from alleged psychological ailments or exhibited overt sexual behavior.

Marineland's successful early years coincided with the postwar revival of a cult of domesticity and the revitalization of the heterosexual nuclear family as the ultimate social ideal in the United States. ${ }^{54}$ Therefore, it is not surprising that Marineland staff, as well as the press, took great interest in Bubbles' sexual life, and incorporated many of her behaviors into an anthropomorphized, heteronormative coming of age narrative. To cure her apparent "loneliness" in the oval fish tank, one paper urged Marineland to "find Bubbles a husband." ${ }^{55}$ When Bubbles refused food for days after swallowing the rubber inner tube, the San Pedro News Pilot wrote that her prolonged fast might be attributed to

\footnotetext{
${ }^{54}$ On the American postwar domestic ideal, see Elaine Tyler May, Homeward Bound: American Families in the Cold War Era (New York: Basic Books, 1988).

${ }^{55}$ Kip Chase, "Bubbles Still Sad; He Whale Ain't He," undated, Kenneth S. Norris Papers UA 66 Box 59, University of California Santa Cruz Special Collections and Archives.
} 
"lovesickness." 56 As part of a press release detailing information about the park,

Marineland public relations staff wrote of Bubbles:

She appears to be the happiest of whales, but Marineland has plans which could make her even happier. One of these days the oceanarium is going to catch a boy whale at sea and bring him to Marineland. And some day in the future there may be a lot of little Bubbles swimming around in the oval tank. ${ }^{57}$

The family unit promised stability and happiness for Bubbles; the promise of captive breeding meant a reliable supply of whales for the oceanarium. Such portrayals of Bubbles assigned a human-like desire for male companionship to her behavior, reflecting the prevailing female gender norm of the postwar era. Without a male partner, Bubbles was unhappy, unwell, and incomplete.

56 “Bubbles Wasn't Lovesick, She Just Needed a Dose of Bicarb," San Pedro News Pilot, July 6, 1957, Kenneth S. Norris Papers UA 66 Box 59, University of California Santa Cruz Special Collections and Archives.

${ }^{57}$ McFadden \& Eddy Associates, "Facts About Marineland of the Pacific Press Release," 6. 


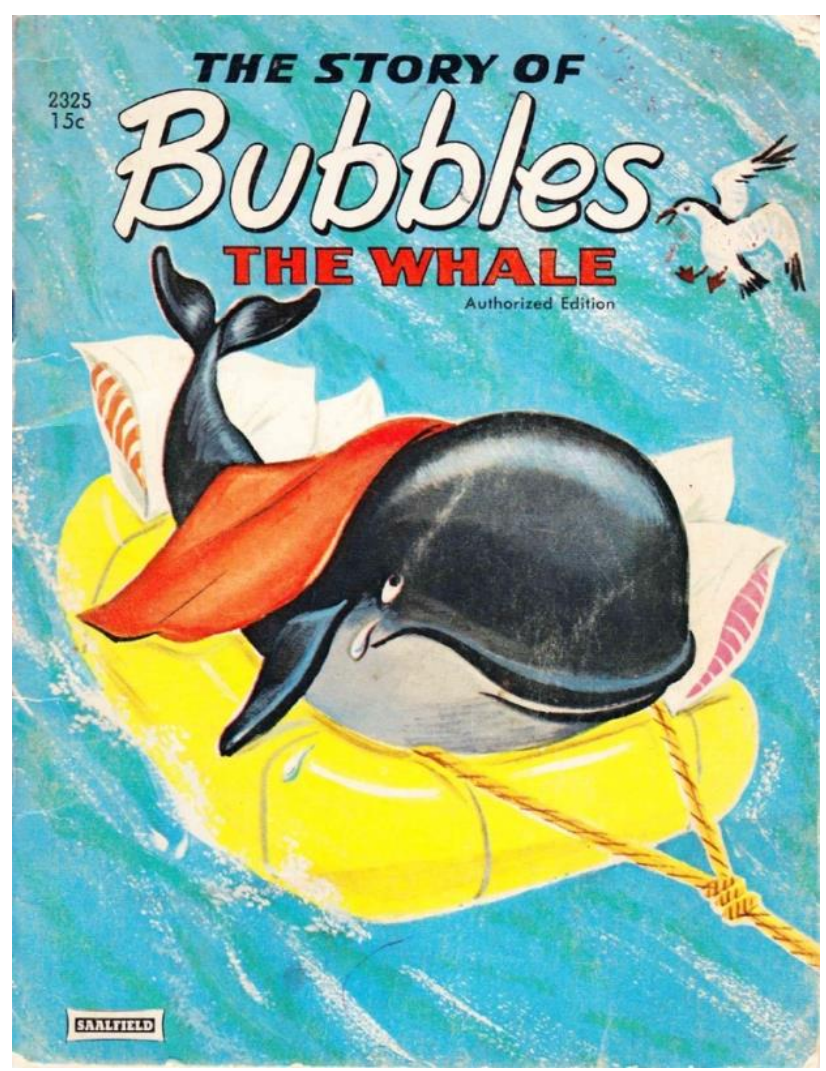

Figure 24. The original front cover image of the 1963 children's book, The Story of Bubbles the Whale. ${ }^{58}$

Children's literature about Bubbles advanced a narrative of a different vein, one that celebrated the whale's physical and emotional journey to captivity at Marineland. ${ }^{59}$ The Story of Bubbles the Whale began with a wild Bubbles, who "smiled almost all the time," and enjoyed playing in the ocean with her friend, Squirt. After seeing a boat approach, the "frightened" whale soon feels a net surround her, and although she attempts

\footnotetext{
${ }^{58}$ Don Hackett, The Story of Bubbles the Whale (New York: The Saalfield Publishing Company, 1963). The second edition of the book, published in 1967, featured a revised front cover in which Bubbles is smiling rather than crying. An image of the 1967 edition appears on page 10 of this thesis.

${ }^{59}$ In the postwar era, children's literature served as an important public relations tool for corporations and organizations to soften potentially disquieting topics for child audiences. Francesca Ammon argues that children's bulldozer stories naturalized and endorsed the process of land clearance in the United States though cheery images of demolition. Francesca Russello Ammon, "Unearthing Benny the Bulldozer: The Culture of Clearance in Postwar Children's Books," Technology and Culture 53, no. 2 (April 2012): 30636.
} 
to escape, she soon finds herself being towed away in a rubber boat. Fat tears stream from the whale's eye in the illustration, and the caption reads: "Bubbles wasn't smiling now." After the fishermen return to Marineland and place Bubbles in the tank, she remains "sad and lonely," and refuses to eat. With some gentle coercion from "Jake the diver" (he said "please") Bubbles begins to eat and starts to smile again. She cheerfully learns "games" from Jake, like wearing a hat, bringing back a ball, and jumping high into the air. But Bubbles, although she is happy and smiling again, still misses her friend Squirt. Just in time, men lower her "best friend" into the tank, and the book concludes with an illustration of the two whales blissfully swimming together at Marineland. ${ }^{60}$ Other Marineland children's stories replicated a similar narrative — a frightening capture experience, initial sadness and loneliness, and happiness once the animal adjusts to a life of captivity and performance — in books written about Marineland's captured dolphins, walruses, and sea elephants. ${ }^{61}$ By presenting a narrative that ended with contentment, Marineland picture books reassured young readers, who might be concerned that captured animals missed their families at sea, that Marineland's animals enjoyed their life in captivity.

According to Marineland's public messaging, not only did pilot whales relish captivity, they adored human company and could be trained like house pets. Some even considered them domesticated. Animal scientists now define the human domestication of animals broadly as a process of sustained, multigenerational artificial selection for

\footnotetext{
${ }^{60}$ Hackett, The Story of Bubbles the Whale, 1963.

${ }^{61}$ For the replication of the same captivity narrative in Marineland children's literature, see Jacobs, Jr., Duncan the Dolphin; Lou Jacobs, Jr., Four Walruses From Arctic to Oceanarium (New York: Young Scott Books, 1968); Lou Jacobs, Jr., Cyra-Nose the Sea Elephant (Chicago: Children's Press, 1973).
} 
desired traits. ${ }^{62}$ This is not to be confused with taming, which the animal behaviorist E. O. Price defines as an "experiential learning process occurring during the lifetime of an individual" animal, in which "an animal's avoidance of people is reduced and willingness to approach people is increased." 63 Because Marineland's pilot whales were captured from the wild, they were tamed, not domesticated. Nevertheless, through promotional material, Marineland public relations staff furthered pilot whales'status as captive domesticates. The picture book Wonders of an Oceanarium proclaimed of Marineland's accomplishment: "At one time few people would have believed that any whale could be captured and domesticated." 64 Bubbles proved that "the whale is not necessarily a fierce monster of the deep," a press release declared, "but can be a playful animal capable of learning tricks like a household pet." 65 In an information booklet about pilot whales sold at Marineland gift shops, former U.S. Fish and Wildlife Service researcher Raymond Gilmore insisted that, although captured from the wild, each pilot whale living in captivity had adjusted to captive life and "is now a semi-domesticated pet."66

Programs on television - a medium that gained immense popularity in the postwar era-paid visits to Marineland and advanced the perception that pilot whales were pet-

\footnotetext{
${ }^{62}$ For a discussion of the issues of defining the domestication process, see Melinda A. Zeder, "Core Questions in Domestication Research," Proceedings of the National Academy of Sciences of the United States of America 112, no. 11 (March 17, 2015): 3191-3198.

${ }^{63}$ For an in-depth explanation of animal taming, see Chapter 15 in E.O. Price, Principles and Applications of Domestic Animal Behavior: An Introductory Text (Cambridge, Mass.: C.A.B. International, 2008).

${ }^{64}$ Jacobs, Jr., Wonders of an Oceanarium: The Story of Marine Life in Captivity, 55.

${ }^{65} \mathrm{McF}$ adden \& Eddy Associates, "Facts About Marineland of the Pacific Press Release," 6.

${ }^{66}$ Raymond M. Gilmore, Bubbles and Other Pilot-Whales (Del Mar, California: Barley Brae Printers, 1962), 1.
} 
like and domesticated. ${ }^{67}$ An episode of the Marineland Carnival variety show, starring the monster family "The Munsters," featured the parents seeking a pet for their son Eddie at Marineland — " "the biggest fish store in the country." Before deciding to take home a sea lion, the family considers a whale as a pet, humorously implying that pilot whales have qualities that would make excellent human companions. ${ }^{68}$ The cast of The Beverly Hillbillies visited Marineland twice in 1964, and in each episode the spirited 'Granny' attempts to capture a whale to cook for dinner. Poking fun at the innocence and simplicity of a family of rural Americans who move to cosmopolitan Southern California, the program relied on the joke that the family believes that Marineland is a place to catch fish, not to watch them. The idea that visitors would come a place to simply observe marine life is incomprehensible to the Clampetts, who are accustomed to hunting for wild game as their primary sustenance. In the episode "Back to Marineland," Granny ropes a pilot whale and is dragged into the pool with the animal. Although she reacts with mock fright, the scene suggested to audiences that being in a tank with a pilot whale was not dangerous. ${ }^{69}$ Contrary to their wildness, television programs sold the idea that captive pilot whales at Marineland were safe to interact with, boasted charming and gentle personalities, and ultimately, were under the full control of a trainer. Such appearances on

\footnotetext{
${ }^{67}$ The television, as the historian Lynn Spigel has pointed out, played a critical role in the formation of values within the home in the postwar United States. In addition to encouraging domesticity and binary gender roles, television programs told viewers how to think about wild animals, which often appeared domesticated and anthropomorphized. For television and the domestic ideal, see Lynn Spigel, Make Room for TV: Television and the Family Ideal in Postwar America (Chicago: University Of Chicago Press, 1992). For television's role in domesticating wild animals, see chapters 5, 6, and 7 in Mitman, Reel Nature: America's Romance with Wildlife on Film.

${ }^{68}$ Bob Lehman, "The Munsters," Marineland Carnival (CBS, April 18, 1965).

${ }^{69}$ Richard Whorf, "The Clampetts Go Fishing," The Beverly Hillbillies (CBS, February 26, 1964); Joseph Depew, "Back to Marineland," The Beverly Hillbillies (CBS, November 4, 1964).
} 
film with Hollywood celebrities, the Palos Verdes News wrote, made Bubbles a "television star."70

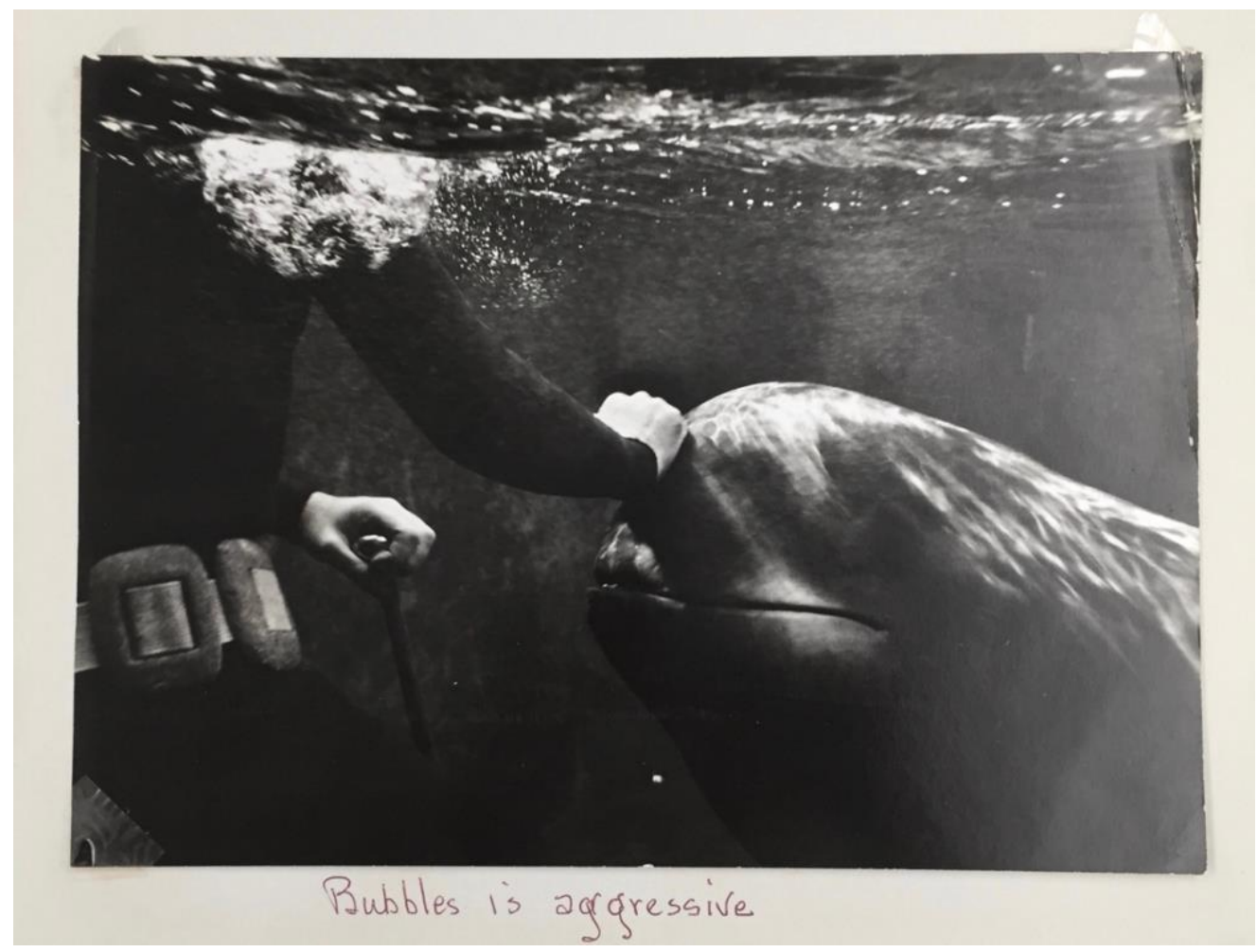

Figure 25. "Bubbles is aggressive." 71

While local newspapers reveled in the notoriety performing whales brought to Marineland, the rosy, the idealized versions of pilot whale personalities seen on television, in children's books, and in promotional literature often conflicted with the realities of the animals' private lives. In addition to Bubbles' violent episodes in the oval fish tank, instances of unexpected sexual activity, aggression, and the refusal to perform

\footnotetext{
70 Bill Campeau, “Lights, Camera, Action... Bubbles Stars on Television," Palos Verdes News Anniversary Edition, May 27, 1965, 20-21.

${ }^{71}$ Bubbles is aggressive. Box 61, Kenneth S. Norris Papers, University of California Santa Cruz.
} 
occurred regularly. Of particular concern to curators and staff was Bimbo, a 17-foot, 3,000-pound male pilot whale the collections crew captured in the Catalina Channel in January 1959. Staff placed Bimbo directly into the tank with Bubbles and Squirt, and the three appeared to bond. On March 8, 1960, when the original Bubbles died after ingesting a stone from the bottom of the tank, Bimbo stunned caretakers when he carried her corpse to and from the surface of the tank by grasping her flipper with his teeth, seemingly in an attempt to allow Bubbles to breathe. After three hours of this behavior, curator David Brown reported that "an erection occurred" and Bimbo repeatedly copulated with the dead female, all the while preventing divers from removing the cadaver from the tank. ${ }^{72}$ In March 1962, Bimbo reacted similarly to the death of Debbie, a female dolphin who shared his tank. For four hours, Bimbo gently carried Debbie's body around, refusing to allow staff to use a harpoon to remove the corpse from the tank. Onlookers observed no sexual behavior in this instance, but the scientists Melba C. Caldwell, David K. Caldwell, and curator David Brown highlighted how Bimbo's eyes, which were open to “approximately twice normal size," gave him a "startled" appearance that betrayed a heightened emotional state. For the rest of the day, Bimbo refused to perform and did not eat for 22 hours. ${ }^{73}$

The deaths of Bimbo's companions seemingly sparked further unwelcomed behaviors that eventually forced Marineland management to retire the animal from the whale show and keep him permanently separated from the other pilot whales. Assuming that pilot whale behavior and physiology mirrored that of humans, Marineland caretakers

\footnotetext{
${ }^{72}$ Brown, "Further Observations on the Pilot Whale in Captivity," 59, 62-63.

${ }^{73}$ Melba C. Caldwell, David H. Brown, and David K. Caldwell, "Intergeneric Behavior by a Captive Pacific Pilot Whale," Los Angeles County Museum Contributions in Science 70 (October 4, 1963): 4, 7-9.
} 
first approached Bimbo's behavior by turning to newly developed psycho-pharmaceutical drugs, which saw a rise in popularity in the midcentury. ${ }^{74}$ The Food and Drug Administration approved the anti-anxiety drug Miltown for human use in 1955, ushering in a new wave of tranquilizers that purported to treat a litany of psychological problems. ${ }^{75}$ Researchers invariably tested these new pharmaceuticals on animals first. ${ }^{76}$ Litter-savaging sows stopped eating their young after scientists dosed them with the tranquilizer chlorpromazine. ${ }^{77}$ When monkeys were given the sedative Ultran (phenaglycodal), they calmed down and appeared tame. ${ }^{78}$ Cattle injected with Trilafon (perphenazine) before boarding a train to a feedlot promptly began eating from the trough after their journey. The stress of transportation usually prevented them from eating normally for days, resulting in a loss for beef producers. ${ }^{79}$

Motivated by the success veterinarians had in treating purported animal neuroses with psycho-pharmaceutical drugs, as well as their effectiveness in humans, Marineland caretakers experimented with tranquilizers and anti-depressants to treat what they believed to be adverse psychological conditions in their pilot whales. In July 1962, Brown and the Caldwells noticed that the female pilot whales in the tank were increasingly falling victim to "unprovoked attack[s]" by Bimbo. Curators intervened by

\footnotetext{
${ }^{74}$ Roy Porter, Madness: A Brief History (New York: Oxford University Press, 2002), 205-6.

${ }^{75}$ Andrea Tone, The Age of Anxiety: A History of America's Turbulent Affair with Tranquilizers (New York: Basic Books, 2009).

${ }^{76}$ Laurel Braitman, "Animal Pharm," in Animal Madness: Inside Their Minds, Second Edition (New York: Simon \& Schuster Paperbacks, 2015), 194-228.

${ }^{77}$ F. K. Kristjansson, "A Note on the Use of Chlorpromazine in the Treatment of Extreme Nervousness and Savageness in Farrowing Sows," Canadian Journal of Comparative Medicine and Veterinary Science 21, no. 11 (1957): 389-90; A. F. Fraser, "Behavior Disorders in Domestic Animals," in Abnormal Behavior in Animals, ed. M. W. Fox (Philadelphia: W. B. Saunders Company, 1968), 179-87.

${ }^{78}$ J. W. Kakolewski, "Psychopharmacology: Clinical and Experimental Aspects," in Abnormal Behavior in Animals, ed. M. W. Fox (Philadelphia: W. B. Saunders Company, 1968), 523-43.

${ }^{79}$ Helen Buechl, “Animal Tranquilizers," The Science News-Letter 74, no. 7 (August 16, 1958): 106-7.
} 
administering the antipsychotic Sparine (promazine hydrochloride), but the drug failed to sedate him enough. ${ }^{80}$ Later that August, Bimbo attacked and killed the smallest pilot whale in the tank, who was "thrown clear of the water by the violence of the assault." 81 Bimbo even devoured the stillborn calf of a recently captured dolphin that shared his tank. ${ }^{82}$ The gravity of Bimbo's shocking behavior spurred Brown to try using pilot whales' tightknit social behavior to break Bimbo's aggression. The park's staff knew pilot whales to be social animals by observing them at sea and in captivity. If Brown could use a frightening experience to bond the animals together, he reasoned, Bimbo's aggression might stop. Brown explained the process:

We drained the water in the tank and stranded him, his 4500 pounds of intelligent meat lying on the bottom, without being able to do a thing, quite helpless and in great fear, and suffering this trauma with him were these females. From that day...he did not show one aggressive move to these females. It welded them together, this bond. ${ }^{83}$

The use of trauma to promote social cohesion applied Brown's understanding of human psychology to animal behavior. Brown admitted to trying out the method after asking himself the question: "What would I do if I had this psychotic dislike of the people that I lived with?" ${ }^{84}$ Since Brown believed that humans bonded if they experienced shared trauma, he thought the experiment might translate to cetaceans. Although the method

\footnotetext{
${ }^{80}$ The lack of Sparine's effectiveness on Bimbo may be attributed to its lesser effects on chronic psychoses. The 1960 Merck Index stipulated the drug was recommended for "acute rather than chronic mental disturbances" in humans, and did not mention whether the drug was effective on animal subjects. Paul G. Stecher, ed., "Promazine," The Merck Index of Chemicals and Drugs (Rahway, New Jersey: Merck \& Co., Inc., 1960).

${ }^{81}$ David H. Brown, David K. Caldwell, and Melba C. Caldwell, "Observations on the Behavior of Wild and Captive False Killer Whales, with Notes on Associated Behavior of Other Genera of Captive Delphinids," Los Angeles County Museum Contributions in Science 95 (April 4, 1966): 25.

${ }^{82}$ Brown, Caldwell, and Caldwell, 7-9.

${ }^{83}$ David H. Brown, "Marvels of Marine Mammals," Noon Topics Lecture, October 23, 1963, Carton 1, Folder 6, UCSF Committee on Arts and Lectures Collection, AR 2015-17. Archives and Special Collections, University of California, San Francisco. ${ }^{84}$ Ibid.
} 
appeared to work temporarily, the use of trauma as a tool of animal control demonstrates the extent Marineland curators went to manage pilot whale behavior.

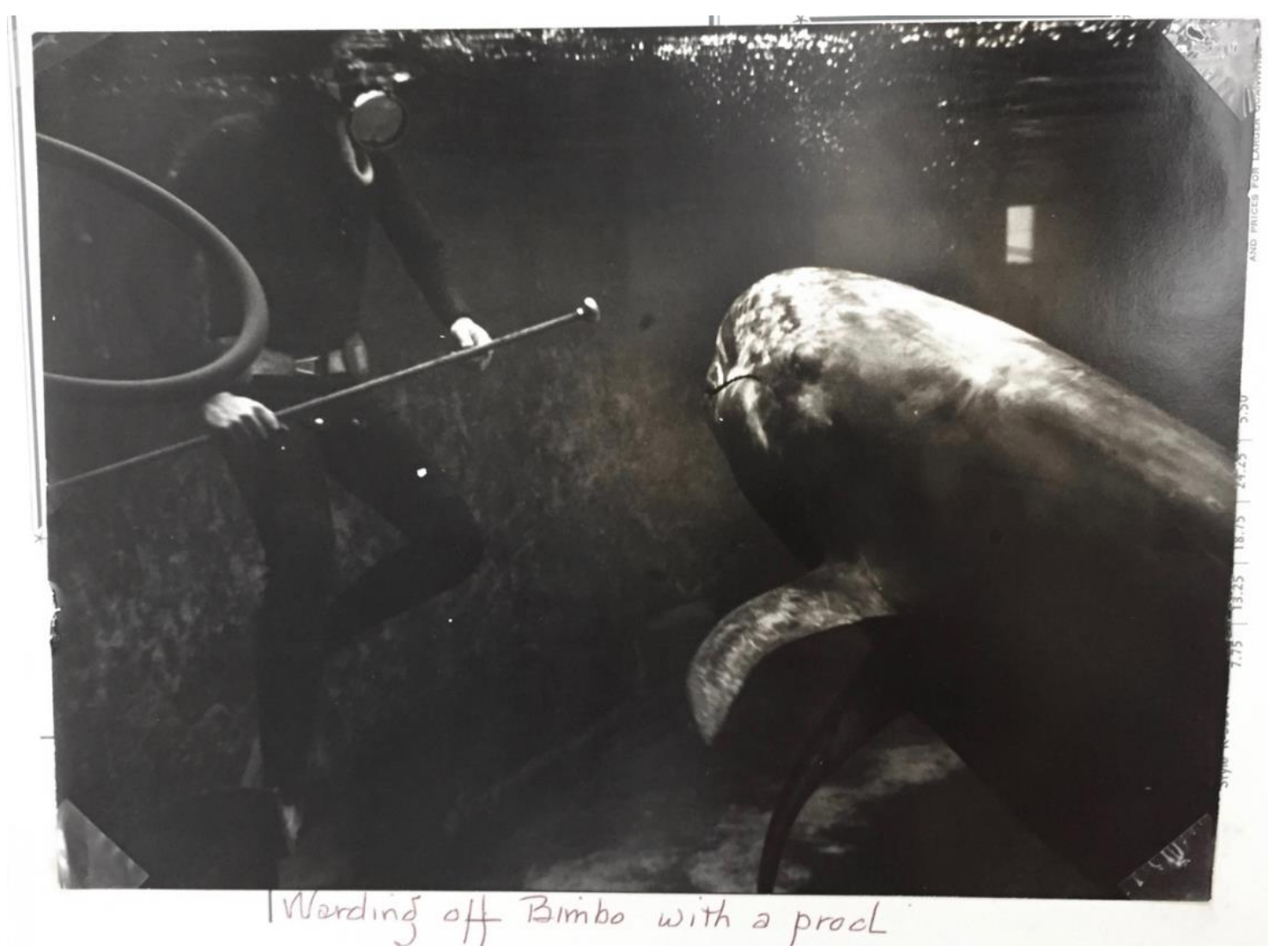

Figure 26. "Warding off Bimbo with a prod." 85

It was not long before the social cohesion between Bimbo and the female pilot whales diminished, and Bimbo was again agitated and refused food. After injecting "massive doses of testosterone" with no avail, Brown consulted the physician M.E. Webber - a doctor with a "keen interest in whale and dolphin research"-who prescribed the new anti-depressant drug Niamid (nialamide) after diagnosing Bimbo with manic

${ }^{85}$ Warding off Bimbo with a prod. Box 61, Kenneth S. Norris Papers, University of California Santa Cruz. 
depressive disorder. ${ }^{86}$ The prescribed dosage for Bimbo's medication seemed like rudimentary guesswork: "We figured that if 75 milligrams is the average Niamid does for an adult [human], 6,000 milligrams would be about right for Bimbo," Webber concluded. ${ }^{87}$ Although Bimbo began to improve with Niamid therapy, he rarely performed for an audience. Marineland officially released Bimbo back into the Catalina Channel in 1967, after he crashed through an observation window, causing water to flood the corridors of the display tank. ${ }^{88}$ In the history of Marineland's captive pilot whales, Bimbo represented a challenge and a nuisance whose ostensible rejection of many aspects of captive life defied the gleeful performer image Marineland assigned to the species.

Bimbo was not the only captive pilot whale who irked curators and staff; other whales engaged in what was seen as embarrassing sexual activity with other cetaceans who shared the tank.$^{89}$ Marineland curators were already familiar with the sexual proclivities of their captive dolphins. Only a year after her capture, Bubbles engaged in masturbatory behavior during what Brown believed to be her estrus cycle; he reported that "the animal constantly rubbed its genital opening on the rocks on the floor of the tank," and "in fact utilized any protuberance available for this purpose." Bubbles even made use of a diver's helmet for such purposes, "much to the man's discomfort," according to Brown..$^{90}$ But pilot whale sexual behavior also extended to other cetaceans in

\footnotetext{
${ }^{86} \mathrm{Ibid}$.

${ }^{87}$ Townsend, "Sad Saga of Bimbo, the Psychotic Whale."

${ }^{88}$ Dorothy Townsend, "'Psychotic Bimbo Banished, Returned to Old Sea Haunts," Los Angeles Times, November 23, 1967; Duane Valentry, "Big Star All at Sea," Sea Frontiers, August 1969.

${ }^{89}$ Far from being a purely human phenomenon, homosexual behaviors occur throughout the animal kingdom. Not to be confused with homosexual orientation or homosexual identity, homosexual behavior denotes discrete acts or interactions between same-sex individuals. For an introduction to animal homosexual behaviors, see Volker Sommer and Paul L. Vasey, eds., Homosexual Behaviour in Animals: An Evolutionary Perspective (New York: Cambridge University Press, 2006).

${ }^{90}$ Brown, "Behavior of a Captive Pacific Pilot Whale," 347.
} 
the tank. In 1960, Brown observed "possible" homosexual behavior between the female Bubbles and a female dolphin: "the dolphin nuzzled the genital opening of the whale, which then did the same to her companion." ${ }^{91}$ Marineland curators would have been familiar with homosexual behavior in cetaceans, since before Marineland's opening, scientists at Marine Studios reported that homosexual behavior had been "observed repeatedly" among the male Atlantic bottlenose dolphins kept there as early as 1940. "Among males there is a good deal of masturbation," the authors of a 1948 article indicated, "on the floor of the tank and against other males." Dominant male dolphins at Marine Studios "repeatedly attempted intromission" with younger, "smaller and subordinate" dolphins. ${ }^{92}$ At Marineland, female pilot whales reportedly had homosexual relations with both a female false-killer whale (Pseudorca crassidens) named 'Swifty' and numerous dolphins. ${ }^{93}$ The first veterinary handbook for captive cetaceans published in 1972, Mammals of the Sea: Biology and Medicine, warned that frequent masturbation and sexual behavior "can be a great source of embarrassment to the management of a public exhibit and thus can present a husbandry problem." ${ }^{94}$ Homosexual behavior in dolphins and whales undoubtedly violated the sexual morals of the postwar period, so curators tried to keep it out of public sight. ${ }^{95}$ Stories of cetacean homosexual behavior

\footnotetext{
${ }^{91}$ Brown, "Further Observations on the Pilot Whale in Captivity," 62.

${ }^{92}$ McBride and Hebb, "Behavior of the Captive Bottle-Nose Dolphin, Tursiops Truncatus," 114-15.

${ }^{93}$ Brown, Caldwell, and Caldwell, "Observations on the Behavior of Wild and Captive False Killer Whales, with Notes on Associated Behavior of Other Genera of Captive Delphinids," 14-15.

${ }^{94}$ Melba C. Caldwell and David K. Caldwell, "Behavior of Marine Mammals," in Mammals of the Sea: Biology and Medicine, ed. Sam H. Ridgway (Springfield, Ilinois: Charles C. Thomas, 1972), 426.

${ }^{95}$ Although sexual values and behaviors were in flux during the postwar period, aversion to certain taboos like homosexuality remained "central tenants of sexual morality." May, Homeward Bound: American Families in the Cold War Era, 111.
} 
never made it to the popular press. ${ }^{96}$ Rigid public morals compelled cetacean scientists to confine discussions of animal homosexuality to academic publications that were rarely read by non-specialists. By engaging in homosexual behaviors, pilot whales at Marineland contested the sexually neutral, heterosexual caricatures constructed and disseminated by the park's public relations staff.

\section{Conclusion}

During Marineland's early years of pilot whale capture and display, the field of marine mammal husbandry was in its infancy. Early veterinary manuals centered on the medical care of livestock, laboratory animals, and domestic pets, and did not include sections on the diagnosis, treatment, and care of marine mammals. Left with scant sources of medical information, early oceanarium curators experimented with their own methods of care. Speaking at the San Francisco Committee on Arts and Sciences Noon Topics Hour in October 1963, David Brown commented on his experiences with cetacean husbandry at Marineland:

"When an animal becomes sick, we now attempt to make a diagnosis. The diagnosis is recorded and then we start off with treatment. The effects of treatment and the treatment are recorded. If the animal recovers, all well and good. If he does not recover and dies, it is then subjected to a gross necropsy. Tissue samples are recovered for histological and cultural studies and the results are all recorded... After we have accrued over a great number of years all of this material, we find ourselves now with our foot on the threshold."97

\footnotetext{
${ }^{96}$ Mitman describes an instance in which the editor of Natural History asked dolphin researcher Frank Essapian to excise a passage on homosexual behavior in from his article on dolphin behavior in 1953. Mitman, Reel Nature: America's Romance with Wildlife on Film, 170.

${ }^{97}$ David H. Brown, "Marvels of Marine Mammals."
} 
As Brown explained, the learning process for developing successful marine mammal veterinary care methods took trial and error, and most importantly, time. In the process, Bubbles, Squirt, Bimbo, and the other pilot whales at Marineland endured the consequences of experimental care. Brown acknowledged that the majority of health problems Marineland staff attempted to treat were related to the stress of captivity and performance, exposing a tension between entertainment and animal health. "I can trace practically $75 \%$ of our veterinary problems at Marineland directly to stressors of one sort of another," Brown conceded. ${ }^{98}$

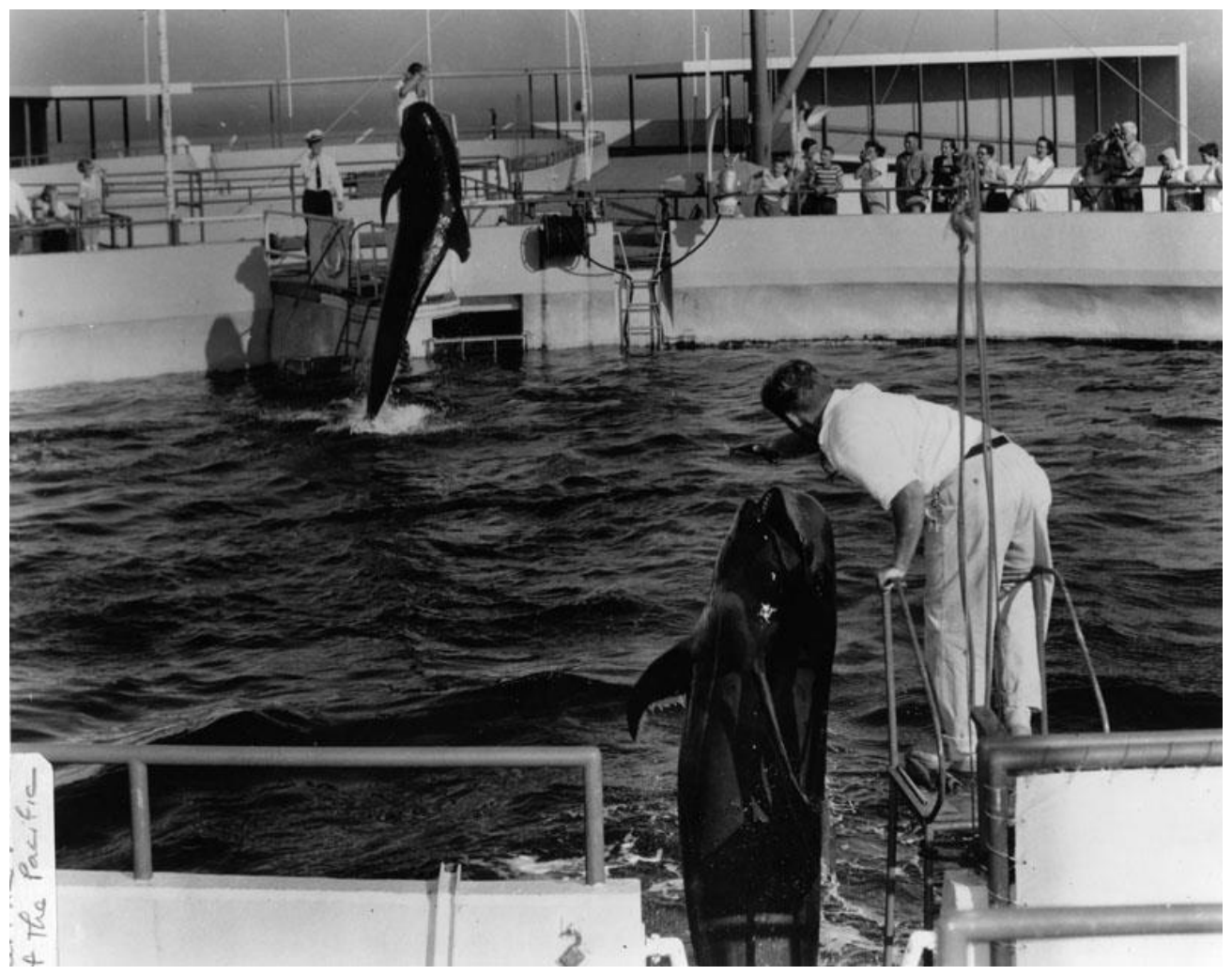

Figure 27. Squirt and Bubbles perform in a pilot whale show at Marineland. ${ }^{99}$

\footnotetext{
${ }^{98}$ Ibid.

${ }^{99}$ Whale show at Marineland, October 14, 1959. Security Pacific National Bank Collection, Los Angeles Public Library.
} 
Despite the experimental character of pilot whale capture, care, and display at Marineland, the public never saw the full extent of the park's attempts to acclimate pilot whales to a life of performing in a captive environment. In 1970, popular wildlife television host Marlin Perkins, along with author Allan Eckert, published In Search of a Whale as part of the Mutual of Omaha's Wild Kingdom book series. The book recounted Perkins' experience joining Marineland staff on a collection mission to capture a pilot whale. In the forward, Eckert opined: “As recently as 1957, these men actually sought, caught, and brought back to captivity a living whale; a pilot whale which they named Bubbles and which still lives in perfect contentment in captivity today, a decade later."100 Marineland never publicized the death of the original Bubbles in 1960, but the spirit of her character lived on, and management simply applied her name to future performers. The capture and exhibition of pilot whales at Marineland represented an experiment in animal collection, spectacle, and marketing for the budding U.S. oceanarium industry. But this experimental period came with unwelcomed aggression, sexual behavior, and whales who refused to perform - complications that challenge the idealized animal personalities common in promotional literature and at times threatened the business of cetacean entertainment. In the history of cetacean capture for oceanarium display, Marineland's innovative methods of capture, care, and training of pilot whales promised public success, paving the way for the capture and display of larger delphinids like killer whales. But the early management of pilot whales at Marineland not only presented

\footnotetext{
${ }^{100}$ Allan W. Eckert, In Search of a Whale, Marlin Perkins' Wild Kingdom (New York: Doubleday \& Company, 1970), 11.
} 
challenges for curators, trainers, and staff. The pioneering spectacle of whales on display often came at the expense of the animals themselves. 


\title{
Chapter 3
}

\author{
"The Most Vicious Animal on Land or Sea"1 \\ The Capture of a Killer Whale in Newport Harbor, California
}

Exception might be taken to the name bestowed upon this whale, on the ground of its indistinctness. For we are all killers, on land and on sea; Bonapartes and Sharks included. -Herman Melville, Moby Dick ${ }^{2}$

Behind the screen of fear and fables which has been cast around the Killer whale lies a fascinating and little-known creature. One day, when the facts have been thoroughly sifted from the tales, the capabilities and intelligence of the Killer may rank it high among all mammals.

In the early morning hours on June 18, 1982, animal care staff at Marineland of the Pacific breathed a collective sigh of relief. After 16 months of pregnancy, the oceanarium's star female killer whale (Orcinus orca) Corky had successfully given birth to a healthy, eight-foot-long, 400-pound calf. But in reality, the battle had just begun. Since Corky had arrived at Marineland in 1969 she had given birth three times, and aside from one born stillborn, two of her calves perished because Corky refused to nurse them. Marineland curator Brad Andrews thought that the whale's reluctance to feed her offspring might be a consequence of being captured so young. Estimated to be only five years old when fishermen captured her in a net in Pender Harbor, British Columbia, Corky may not have had enough time to learn critical nursing behaviors from the older female whales in her pod. So when staff discovered that Corky was pregnant for the

1 "5,000 See Killer Whale Captured at Newport," Los Angeles Times, November 19, 1961, A6.

${ }^{2}$ Melville, Moby Dick, 1:176.

${ }^{3}$ Kenneth S. Norris, "Facts and Tales About Killer Whales," Pacific Discovery, February 1958, 27. 
fourth time, Marineland initiated a training program that the Los Angeles Times called "lessons in motherhood," including teaching her to nurse a fiberglass calf replica on command and accept a milking machine. And for over a year, staff veterinarians collected blood samples containing Corky's valuable antibodies which could be injected into the calf if Corky was again unwilling to care for her young. ${ }^{4}$

Three days passed, and despite the attempts of staff, Corky again did not nurse her calf. She also refused to lie still long enough to let caretakers operate the milking machine. To prevent starvation, veterinarians intervened and force-fed the infant a formula of pasteurized milk, whipping cream, lacitate (to break down the lactic acid in cow's milk), casein, and serum from Corky's blood. ${ }^{5}$ After a few days on the formula diet, caretakers were optimistic. "For the first time we have a calf that is stable," assistant curator Tim Desmond told the Times. "We have never been able to get a calf this far before, where its able to maintain its strength and body weight." ${ }^{26}$ By late July however, staff noticed that Corky was beginning to act aggressively toward the calf, bumping and pushing the infant away. In the interest of the calf's survival, staff separated the baby whale from her mother by placing her in smaller tank with a dolphin as a companion. But after a little over a day in the new pool, the 46-day-old calf died. Marineland's curatorial staff attributed the death primarily to the distress caused by separating infant from

\footnotetext{
${ }^{4}$ Robin Heffler, "Pregnant Corky Takes Lessons in Motherhood," Los Angeles Times, September 3, 1981, SB1; Sandi Weisel, "Great Expectations at Marineland," Los Angeles Times, February 12, 1982, CS18; Dorothy Townsend, "Baby Whale, Mama Doing Fine So Far," Los Angeles Times, June 19, 1982, B1. ${ }^{5}$ Dorothy Townsend, "Whale Calf Fed Formula as Mother Spurns Milking," Los Angeles Times, June 23, 1982, B25.

${ }^{6}$ Dorothy Townsend, “Baby Whale Stable; Public Gets First View," Los Angeles Times, June 27, 1982, B1-2.
} 
mother. "It's so fragile... It's a house of cards. You think you've made it, and suddenly it goes poof," Desmond lamented. ${ }^{7}$

Corky's unnamed calf was not the first killer whale to die in a Marineland tank, nor would it be the last. A male named Orky, who arrived at the park in 1967 from British Columbia, survived only two years after succumbing to pneumonia. The first female orca to be named Corky (Corky I) who came to Marineland in 1968 also lived two years before dying from a severe abscess. And Corky's fifth calf, born in 1985, survived only four weeks before it regurgitated the human-made whale formula and asphyxiated. But roughly two decades before, the presence (and subsequent death) of the first orca to inhabit a Marineland pool sent shockwaves through the budding marine mammal captivity industry. The whale, a sick and disoriented adult female captured in 1961 by Marineland collectors in Newport Harbor, California, was the first orca ever to be caught and displayed in an aquarium. Although the whale, named Wanda by the local press, survived little over a day in Marineland's oval display tank, the success of her brief captivity launched a new entertainment possibility for aquariums across the globe.

As an institution in the business of exhibiting marine life, Marineland was not afraid to take risks attempting to display a diverse range of dolphin and whale species. After pioneering the open-ocean collection of Pacific dolphins in the mid-1950s, Marineland collectors were the first to successfully capture a short-finned pilot whale in 1957, which at the time was the largest cetacean ever displayed. But no aquarium had yet

\footnotetext{
${ }^{7}$ Dorothy Townsend and Jack Jones, "Marineland's Baby Killer Whale Dies," Los Angeles Times, August 4, 1982, C1; Dorothy Townsend, "Stress Blamed in Baby Whale's Sudden Death," Los Angeles Times, August 5, 1982, E1; Dorothy Townsend, "Baby Needed Its Mother: Separation Blamed in Whale Death," Los Angeles Times, August 5, 1982, sec. OC, A2; Sandi Weisel, "Death of Corky's Bundle of Joy: Marineland Experts Still Ask Why," Los Angeles Times, August 27, 1982, 26.
} 
attempted to capture the famed killer whale, whose dangerous reputation was well known. Prior to Wanda's capture, aquarium operators feared that killer whales might be too unpredictable or aggressive for public exhibition. Popular perceptions of the animal were colored by centuries of observations by fishermen, explorers, and whalers, who cast the orca as a savage and bloodthirsty predator that had a taste for human flesh, despite a lack of authenticated reports that whales had ever injured humans at sea. While Wanda repeatedly dodged and attempted to evade the nets of her captors in the Newport harbor turning basin, she proved docile enough upon capture to be loaded onto a truck and placed into a Marineland tank without harming any of the collections staff. Because Wanda reacted to the stress of capture much like the dolphins and pilot whales Marineland had captured before, the experience promised that a second attempt - perhaps with a healthier whale - might be even more fruitful.

Marineland's experience with Wanda also gave the oceanarium's management a taste of the crowd-drawing potential that killer whales could provide. Local newspapers reported that anywhere from 5,000 to 8,000 people came to observe the nine-hour-long capture event. In an effort to capitalize on the possibilities of creating a killer whale exhibit, in 1962 Marineland was the first North American marine park to launch a capture mission to the orca-rich waters of the Salish Sea region. Although the collections team failed to capture a second whale in the waters off Washington state, it was the first expedition of its kind in the Salish Sea, an area that by the end of the decade would supply the bulk of killer whales to North American aquariums.

Historian Jason Colby has shown that as a result of public exhibition beginning in the 1960s, North American perceptions of the killer whales transformed from cunning sea 
wolves to enigmatic oceanarium performers and icons of the environmental movement. ${ }^{8}$ By familiarizing audiences with these previously detested marine predators and training them to perform circus-like tricks, places like the Vancouver Aquarium, Sealand of the Pacific, and SeaWorld caused public perceptions of the species to evolve. Although Marineland held a killer whale only briefly and their later capture attempts failed, the park's early bids to capture orcas are a critical yet unexamined aspect of the dramatic change in perception of the species that took place during the mid-twentieth century.

\section{Perceptions of Killer Whales Prior to Captivity}

Portrayals of killer whales as vicious, murderous beasts were rooted in the oral and written accounts of sailors, fishermen, and whalers, whose observations of killer whale behaviors at sea found their way into nineteenth-century natural history texts. Written accounts of the species' ferocity can be traced to even as far back as the writings of Pliny the Elder, who, in describing the orca as a predator of larger whales, wrote that the animal could only be described as "an enormous mass of flesh armed with teeth" that launched attacks in secluded bays where larger whales birthed their calves. ${ }^{9}$ Centuries later, The Natural History of Quadrupeds, and Cetaceous Animals (1811) identified the creature by its more common British name - the grampus. Although the grampus possessed a "ferocious disposition" as a hunter, the book noted the animal's strong "parental affection" for their offspring, relating a tale of a grampus who valiantly

\footnotetext{
${ }^{8}$ Colby, "The Whale and the Region: Orca Capture and Environmentalism in the New Pacific Northwest"; Colby, "Changes in Black and White: Killer Whale Bodies and the New Pacific Northwest."

${ }^{9}$ Pliny the Elder, "Book IX: The Natural History of the Fishes," in The Natural History of Pliny, trans. John Bostock and H. T. Riley, vol. 2 (London: Henry G. Bohn, 1855), 365-66.
} 
defended "her cub" from fishermen attempting to slaughter the stranded pair at low tide. ${ }^{10}$ The Victorian naturalists William Jardine and Robert Hamilton, who devoted the sixth volume of the Mammalia collection of The Naturalist's Library series to cetaceans, wrote that the grampus — which Americans called "the Killer or Thrasher" for "its reputed pugnacious and cruel disposition" — had an "exceedingly voracious and warlike" character. The book retold a harrowing story of a grampus found swimming in the Thames river in 1772; even after local men harpooned the whale three times, the creature was "for a long time unimpeded by the lance-wounds," pulling the attached boat twice from Blackwall to Greenwich against the tide before finally giving in. ${ }^{11}$

The Danish zoologist and anatomist Daniel Frederik Eschricht was among the first to provide evidence of the orca's voracious appetite. His posthumously published 1866 paper "On the Northern Species of Orca" documented Eschricht's dissection of a male killer whale carcass near the town of Randers in Jutland, which revealed the remains of 13 porpoises and 14 seals inside the animal's stomach compartments. ${ }^{12}$ Scientific discussions of the orca's predatory behavior often included a reference to Eschricht's extraordinary discovery, while newspapers and popular natural history

\footnotetext{
${ }^{10}$ The Natural History of Quadrupeds, and Cetaceous Animals, vol. 2 (Bungay, England: Brightly and Co., 1811), 410-11.

${ }^{11}$ Robert Hamilton, The Naturalist's Library: Mammalia, Whales, \&tc, ed. William Jardine, vol. 26 (Edinburgh: W. H. Lizars, 1837), 223-31. Evidently, orcas were frequently found swimming in the Thames; the naturalist Henry William Dewhurst reported that six grampuses were killed in the Thames in 1793 alone. See Henry William Dewhurst, The Natural History of the Order Cetacea, and the Oceanic Inhabitants of the Arctic Regions (London: Henry William Dewhurst, 1834), 182.

${ }^{12}$ D. F. Eschricht, "On the Species of the Genus Orca Inhabiting the Northern Seas," in Recent Memoirs on the Cetacea by Professors Eschricht, Reinhardt and Lilljeborg, ed. William Henry Flower (London: Robert Hardwicke, 1866), 153-88.
} 
publications recited his finding to bolster claims of the species' ferocity and insatiable hunger for flesh. ${ }^{13}$

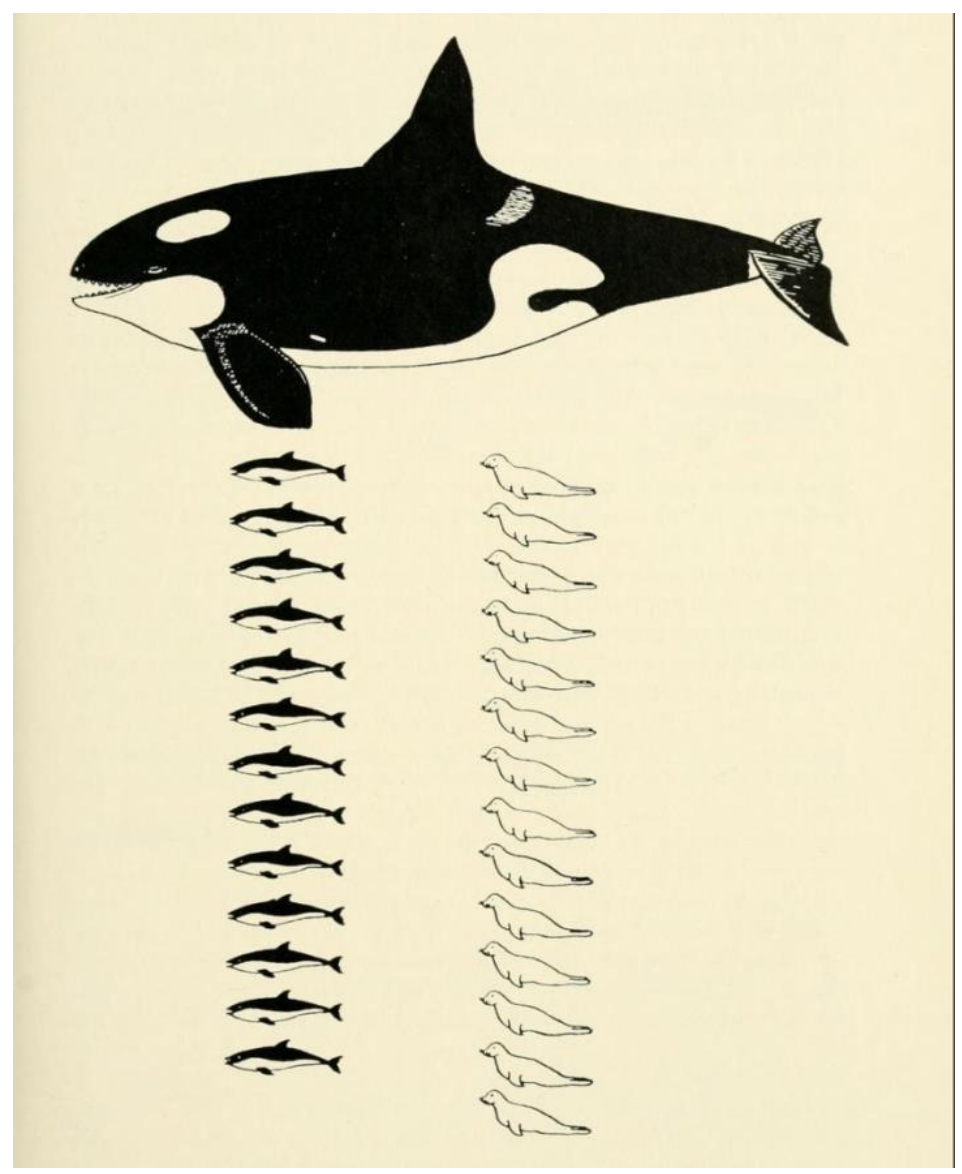

Figure 28. A visual representation of Eschricht's famous orca dissection, from a 1962 book by the Dutch cetologist E. J. Slijper. ${ }^{14}$

In addition to describing killer whale behavior, morphology, and anatomy,

naturalists who studied cetaceans struggled with how to place the animal taxonomically.

\footnotetext{
${ }^{13}$ For examples of Eschricht's findings in natural history books, see Scammon, The Marine Mammals of the North-Western Coast of North America, 91; Thomas Southwell, The Seals and Whales of the British Seas (London: Jarrold and Sons, 1881), 113-15. For examples in newspapers, see C. William Beebe, "Midgets and Giants of the Animal World," New York Tribune, October 6, 1907, 6.

${ }^{14}$ E. J. Slijper, Whales, trans. A. J. Pomerans (New York: Basic Books, 1962), 275.
} 
Not until 1758 did the tenth edition of Carl Linnaeus' Systema Naturae class whales as mammals. From the late eighteenth through the nineteenth century, taxonomical classifications for cetaceans were in constant flux, often changing when new information necessitated rearrangements. ${ }^{15}$ Linnaeus originally identified only one species of killer whale (Delphinus orca), while the French naturalist Pierre Joseph Bonnaterre added the species Delphinus gladiator in 1789 to designate orcas with larger dorsal fins. ${ }^{16}$ The size of the whale's fins continued to inspire scientific debates about the number of orca species in existence. Paleontologist and anatomist Edward Drinker Cope, in a paper published with the whaler and naturalist Charles Melville Scammon in 1869, identified two other distinct species of orca that lived in northern Pacific waters-Orca rectipinna and Orca ater - based upon the height of their dorsal fins and their varied coloration. ${ }^{17}$ Male orcas do not begin to develop their characteristic three to six foot tall triangular dorsal fin until after they reach sexual maturity in their teens, which explains how early scientists could have easily dissected male orcas with small fins and mistook them for a separate species. ${ }^{18}$

While the captain of a whaling vessel in the North Pacific, Scammon observed killer whales hunting a variety of prey, but his description of an attack on a mother

\footnotetext{
${ }^{15}$ Carl Linneaus, Systema Naturae per Regna Tria Naturae: Secundum Clases, Ordines, Genera, Species, Cum Characteribus, Differentiis, Synonymis, Locis., 10th ed., vol. 1 (Stockholm: Laurentii Salvii, 1759), $17-19$.

${ }^{16}$ Linneaus, 1:77; Pierre Joseph Bonnaterre, Tableau Encyclopédique et Méthodique Des Trois Régnes de La Nature: Cetologie, vol. 126 (Paris: Charles Joseph Panckoucke, 1789), 22-24.

${ }^{17}$ Charles M. Scammon and Edward D. Cope, "On the Cetaceans of the Western Coast of North America," Proceedings of the Academy of Natural Sciences of Philadelphia 21 (1869): 22. For a primer on Scammon's contributions to natural history, see Lyndall B. Landauer, "Charles M. Scammon: From Seaman to Civilized Whaler to Naturalist," California History 61, no. 1 (1982): 46-57.

${ }^{18}$ John K. B. Ford, "Killer Whale (Orcinus Orca)," in Encyclopedia of Marine Mammals, ed. William F. Perrin, Bernd Würsig, and J. G. M. Thewissen, 2nd ed. (New York: Academic Press, 2009), 655.
} 
California gray whale (Eschrichtius robustus) and her calf gave readers a haunting image of the orca's killing methods. "The attack of these wolves of the ocean upon their gigantic prey may be likened, in some respects, to a pack of hounds holding the stricken deer at bay," Scammon wrote; "They cluster about the animal's head... while others seize it by the lips and haul the bleeding monster under water." Despite their propensity for hunting all manner of marine mammals themselves, Scammon positioned the species as a nemesis to whalers by claiming that a group was observed stealing whale carcasses from whaling ships. "Although [the orcas] were frequently lanced and cut with boatspades, they took the dead animals from their human captors, and hauled them under water, out of sight," the captain alleged ${ }^{19}$ Much like Eschricht's discovery of the contents of an orca's stomach, newspapers often included versions of Scammon's description of orca thievery in coverage of killer whales, which further perpetuated negative perceptions of the animal. ${ }^{20}$

Tales about orcas preying on humans did not appear until the turn of the century, when Antarctic explorers began to write about close encounters with killer whales in the region. During the 1910 Terra Nova Expedition to reach the South Pole, British explorer Robert Falcon Scott recorded an instance in which killer whales rammed an ice floe seemingly in an attempt to get at the crew's photographer and some of the sledge dogs. As the whales' "huge, hideous heads shot vertically into the air," Scott wrote in his journal, the team saw "their terrible array of teeth—by far the largest and most terrifying

\footnotetext{
${ }^{19}$ Scammon, The Marine Mammals of the North-Western Coast of North America, 90.

${ }^{20}$ For examples of Scammon's description of orca behavior in newspaper accounts, see "Killers in Monterey Bay," Daily Alta California, August 6, 1871, 3; "A Battle Between Leviathans," The Marin Journal, October 11, 1894, 4; "Fish That Knows No Fear," Sausalito News, May 17, 1919, 4.
} 
in the world." Although Scott had not initially considered killer whales to be a serious threat, their "deliberate cunning," ability to break through ice, and capacity to "act in unison" changed his mind. Scott concluded his entry for that day: "It is clear that they are endowed with singular intelligence, and in future we shall treat that intelligence with every respect." ${ }^{21}$ According to Scott, orcas were no longer exclusively a danger to the local fauna, these ocean predators were now a threat to humans, too.

When American newspapers received news of the Terra Nova's confrontation with killer whales, journalists spun the attack into the larger tale of tragedy that surrounded the expedition. Captain Scott and a small party, who left the rest of the expedition members stationed at the Cape Evans base camp to reach the South Pole, died on the return journey. Like the extreme weather and unpredictable ice floes, killer whales became part of the myriad threats present in the Antarctic landscape. ${ }^{22}$ Movie theatres across the country soon showed the silent film sequences of killer whales hunting seals shot by the expedition's photographer Herbert Ponting — likely the first time killer whales appeared on film—which Ponting later made into the 1924 motion picture The Great White Silence. ${ }^{23}$ Although no killer whales ever harmed Antarctic explorers, the maneating image stuck, persisting until midcentury. Even the prominent whale conservationist Remington Kellogg, who resisted the desires of National Geographic

\footnotetext{
${ }^{21}$ Robert Falcon Scott, Scott's Last Expedition, vol. 1 (New York: Dodd, Mead \& Company, 1913), 65-66. 22 “Misfortune Dogged Capt. Scott's Steps: Antarctic Hero's Diary Shows an Indomitable Will Fighting Great Odds from the Start," New York Times, June 24, 1913, 4. Some American newspapers explicitly denounced the killer whale as the Antarctic's foremost threat. For example, see "Terror of the Antarctic--A Man-Killing Whale," The Times Dispatch, November 16, 1913, 53.

23 "Sea Tragedy on Films: Capt. Scott's Companion Gets a Combat of Whales and Seal in Moving Pictures," New York Times, June 27, 1912, 8; "Antarctic Perils Shown on Screen: Moving Pictures of Captain Scott's South Pole Expedition at Clunie Two Days," The Sacramento Union, December 12, 1913, 4; Herbert Ponting, The Great White Silence (Gaumont British Distributors, 1924).
} 
editors to portray cetaceans as deep-sea monstrosities in the 1940 feature article "Whales, Giants of the Sea," warned readers of the possible danger killer whales posed to humans. Although Kellogg sought to alert public attention to the exploitation of whale stocks by depicting them in a more positive light, the description he wrote to accompany the illustration of killer whales mid-hunt claimed the species "can swallow a seal or even a man."24

While the orca's awesome capabilities as an ocean predator dominated human thinking about the species for centuries, seamen often attempted to eradicate killer whales to prevent them from diminishing fish or seal stocks. In 1897, citing former New Bedford whaling captain Edward Herendeen, the Washington D.C. The Evening Star condemned the killer whale as "responsible in large measure" for the diminution of seal rookeries. The whaler attested to finding nineteen seal pups in the stomach of a killer whale that stranded itself pursuing seals in shallow water. ${ }^{25}$ Scripps Institution biologist Winfred Allen, echoing Herendeen's concern decades later in his California newspaper science column, decried the loss of an estimated " $\$ 1,000,000$ worth of seals" supposedly killed by orcas each year. "It will pay just as well to kill 'wolves of the sea' as it does in case of wolves on land," Allen contended, but "it is not likely that much can be done against them without subsidy or bounty unless the United States navy should send some of its smaller vessels to kill them." ${ }^{26}$ In an era of government-funded predator extermination,

\footnotetext{
${ }^{24}$ Remington Kellogg, "Whales, Giants of the Sea," National Geographic, January 1940, 53. Kellogg worked extensively with the artist Else Bostelmann to create three dozen vibrant color paintings of various whale species for the article. By depicting whales in their true form, the historian Graham Burnett argues, Kellogg and Bostelmann challenged traditional representations of whales as grotesque monsters. Burnett, The Sounding of the Whale: Science and Cetaceans in the Twentieth Century, 311-19.

25 "Destruction of the Seals," Evening Star, October 20, 1897, 11.

${ }^{26}$ Winfred E. Allen, "Wolves of the Sea," The Sacramento Union, July 30, 1922, 7.
} 
Allen's proposition fell in line with the popular American belief that eradicating large carnivores was integral to the preservation of game species and livestock. ${ }^{27}$

The U.S. Navy did eventually engage in the large-scale culling of orcas in 1954, when G.I.s stationed at a NATO airbase answered the Icelandic government's plea to deal with killer whales that fishermen claimed were destroying fishing tackle. After eliminating hundreds of "savage sea cannibals" with rifles and machine guns, Time magazine lauded the mission as "very tough on the whales...but very good for AmericanIcelandic relations. ${ }^{28}$ In 1955 , the Navy launched a second extermination campaign to rid Iceland's coastal areas of killer whales, this time adding rockets and depth charges to their whale-killing arsenal. Without the help of the U.S. Atlantic fleet, Naval Aviation News declared, damage from killer whales "threatened to cut the Icelandic fish catch in half." ${ }^{29}$ In the Pacific Northwest, Canadian officials responded to fishermen's concerns about dwindling salmon harvests by installing a machine gun along Seymour Narrows on Vancouver Island in 1959 specifically to gun down killer whales that passed by. Although the risk of forest fires from a hot and dry summer prevented the gun from ever being used, the weapon was a testament to fishermen's suspicion and disdain for the

\footnotetext{
${ }^{27}$ For a history of government eradication programs targeting large carnivores in the U.S. West, see Frank Van Nuys, Varmints and Victims: Predator Control in the American West (Lawrence, Kansas: University Press of Kansas, 2015). For a focus on wolf extermination specifically, see Ch. 9 "Annihilation and Enlightenment: The Cultural Extinction of North American Wolves" in Jon T. Coleman, Vicious: Wolves and Men in America (New Haven: Yale University Press, 2004), 191-224. For the history and economic importance of North American sealing, see Briton Cooper Busch, The War Against the Seals: A History of the North American Seal Fishery (Montreal: McGill-Queen's University Press, 1985); Michael Bhargava, "Of Otters and Orcas: Marine Mammals and Legal Regimes in the North Pacific," Ecology Law Quarterly 32, no. 4 (2005): 947-56.

28 "Iceland: Killing the Killers," Time, October 4, 1954; "U.S. Troops in Iceland Receive Whale of a Job," New York Times, September 22, 1954, 2.

29 "Killer Whales Destroyed: VP-7 Accomplishes Special Task," Naval Aviation News, December 1956, 19. The U.S. Navy launched a third extermination campaign in August 1956, this time deploying the Neptune PB-2V plane to bomb the whales. See "U.S. Bombing Killer Whales," New York Times, August $15,1956,3$.
} 
species. ${ }^{30}$ Unlike the dolphins and pilot whales Marineland had captured before-which many simply thought of as pests or as sources of lubricating oils-killer whales had amassed centuries of negative stereotypes that often brought humans and whales into violent confrontations with one another. But public display would quickly transform the vicious, predatory killer whale into a charismatic and gentle oceanarium performer, and Marineland of the Pacific was poised to put that transformation into motion.

\section{Preparing to Capture the Ocean's Top Predator}

Marineland collectors encountered killer whales in Southern Californian waters almost as soon as they initiated animal collecting expeditions for the park in 1954. While on a mission off the coast of Santa Barbara in November, Marineland's head curator Kenneth Norris, skipper Frank Brocato, and first mate Frank Calandrino observed a group of eight killer whales feasting on basking sharks (Cetorhinus maximus) accidentally caught in a local fishermen's net the day before. An adult female, her mouth filled with fragments of shark flesh, even swam under the stern and rolled over as she passed the boat. ${ }^{31}$ Killer whales were common enough in the area that Marineland staff occasionally saw them from shore. That December, Norris and assistant curator David Brown observed ten whales only 150 feet offshore of the oceanarium grounds on Portuguese Bend, two of which leapt clear out of the water. ${ }^{32}$

\footnotetext{
${ }^{30}$ Murray Newman, Life in a Fishbowl: Confessions of an Aquarium Director (Vancouver: Douglas and McIntyre, 1994), 81.

31 "Kenneth S. Norris Field Notes," 256; Norris and Brown, "Observations of Captive and Wild Cetaceans," 325.

${ }^{32}$ Norris and Brown, "Observations of Captive and Wild Cetaceans," 325.
} 
Killer whales were not the only cetaceans unfamiliar to Marineland curators, and when the opportunity arose, collectors Brocato and Calandrino experimented with capturing new species to add to Marineland's displays. Using the salmon hook capture apparatus Brocato initially developed to capture pelagic dolphins, collectors snagged a Dall's porpoise (Phocoenoides dalli) in February 1956 that, upon capture, surprised the crew with "frenzied beatings of its tail" when brought aboard the skiff. The animal died minutes later. Other Dall's reacted similarly to the stress of capture; according to Norris, one adult male gave a "mighty struggle" for a few minutes, then "emitted a squeal, regurgitated about a bucketful of squid, and died." Only one Dall's managed to survive long enough onboard to be brought back to the oceanarium. Norris reported that the animal's eyes had been damaged somehow during the capture struggle, and once placed into Marineland's circular display tank, the porpoise repeatedly battered itself on the walls. Although staff relocated the Dall's to a shallow holding pool and into a restraining sling, caretakers found the animal dead the next morning. ${ }^{33}$ Because the Dall's is a fast moving, hyperactive cetacean well-adjusted to life in the open ocean, subsequent attempts by North American aquariums and research facilities to maintain the species in captivity often failed. ${ }^{34}$

\footnotetext{
${ }^{33}$ Norris and Prescott, Observations on Pacific Cetaceans of Californian and Mexican Waters, 63:352-54.

${ }^{34}$ For a brief discussion of the issues with capturing Dall's porpoises, see G. Victor Morejohn, "The Natural History of Dall's Porpoise in the North Pacific Ocean," in Behavior of Marine Animals: Current Perspectives in Research Volume 3: Cetaceans, ed. Howard E. Winn and Bori L. Olla, vol. 3 (New York: Plenum Press, 1979), 70. The U.S. Navy's Marine Mammal Program facility at Point Mugu, California attempted to maintain Dall's in captivity in the early 1960s, but few animals survived longer than 26 days. However, one individual named Marty survived for 21 months and was trained by doctoral student Deborah Duffield, who later went on to become a biology professor at Portland State University. See Wood, Marine Mammals and Man: The Navy's Porpoises and Sea Lions, 41-45.
} 
Local authorities and fishermen often notified Marineland personnel when cetaceans appeared stranded or sickly in waters off Los Angeles, and occasionally the collecting crew brought these animals back to the park and attempted to rehabilitate them. In February 1956, Marineland collectors responded to the call of a Santa Catalina island diver and his son who found a rare Cuvier's beaked whale (Ziphius cavirostris) stranded on a beach near Avalon harbor. The whale barely objected when the crew hauled her onto a mattress aboard the Geronimo's skiff, administered shots of penicillin, and towed her back to the oceanarium. Norris arranged to have the animal placed in the oval display tank that held main fish collection. When staff placed the whale they named Martha (because she was captured on President Washington's birthday) into the tank that evening, she initially appeared to adjust to her captive environment. But by daybreak, Norris and assistant curator John Prescott reported that Martha began rapidly circling the tank, progressing into a "frenzy" that churned "the entire tank into a froth." After swimming the entire length of the 100-foot pool, the whale crashed at full speed into the far wall. Caretakers swiftly escorted Martha to the connecting flume way and curator Brown injected a shot of adrenaline, but his action proved not enough. A necropsy revealed Martha had a broken her jaw in the collision but was also "seriously ill" with congestion of the lungs. ${ }^{35}$ The animal's long-term ailment is likely why she stranded in the first place.

\footnotetext{
${ }^{35}$ Norris and Prescott, Observations on Pacific Cetaceans of Californian and Mexican Waters, 63:304-6; "Rare Whale Lassoed, Taken to Aquarium," Los Angeles Times, February 23, 1956, 2; "Whale of an Autopsy Due," Palos Verdes News, March 15, 1956, 12. The Cuvier's beaked whale, also known as the Goose-beaked whale, can grow to be 23 feet long. The species is found in deep offshore tropical to cool temperate oceans across the globe, where they primarily hunt for squid. Randall R. Reeves et al., "Cuvier's Beaked Whale," in National Audubon Society Guide to Marine Mammals of the World (New York: Alfred A. Knopf, 2002), 254-57.
} 
The risking-taking ethos that embodied Marineland's early collecting practices nearly capped 1956 with the capture of a young killer whale. While cruising off the coast of San Diego that December, the crew encountered a group of eight killer whales. Some of the whales steadily approached the Geronimo, and twice an adult female leapt out of the water 20 yards from the boat, accompanied by a seven-foot calf. When the pair came near enough, Captain Brocato took his place in the "porpoise pulpit" overhanging the bow of the vessel and took a swing at the calf with the snare. He missed. Norris recounted that the female "turned her head and peered up at the collector directly above her," while the crew shouted: "Look out, she's coming for your legs." This gave Norris enough time to briefly observe the calf, which he judged to be only a few days old, based on the lemon-yellow color of the animal's lighter patches and creased skin. ${ }^{36}$ If the crew had been successful, it is unclear how Marineland caretakers would have sustained an infant orca that would subsist on mother's milk for up to two years. ${ }^{37}$ But more so Norris feared the whale pack's probable retaliation if Brocato had actually snared the calf. When he retold the story for an article in Natural History, Norris wondered: "Who knows what might have taken place if the young animal had been successfully snared?"38

\footnotetext{
${ }^{36}$ Norris and Prescott, Observations on Pacific Cetaceans of Californian and Mexican Waters, 63:330-32. ${ }^{37}$ Randall R. Reeves et al., "Killer Whale," in National Audubon Society Guide to Marine Mammals of the World (New York: Alfred A. Knopf, 2002), 438-39.

${ }^{38}$ Norris, "Facts and Tales About Killer Whales," 27.
} 


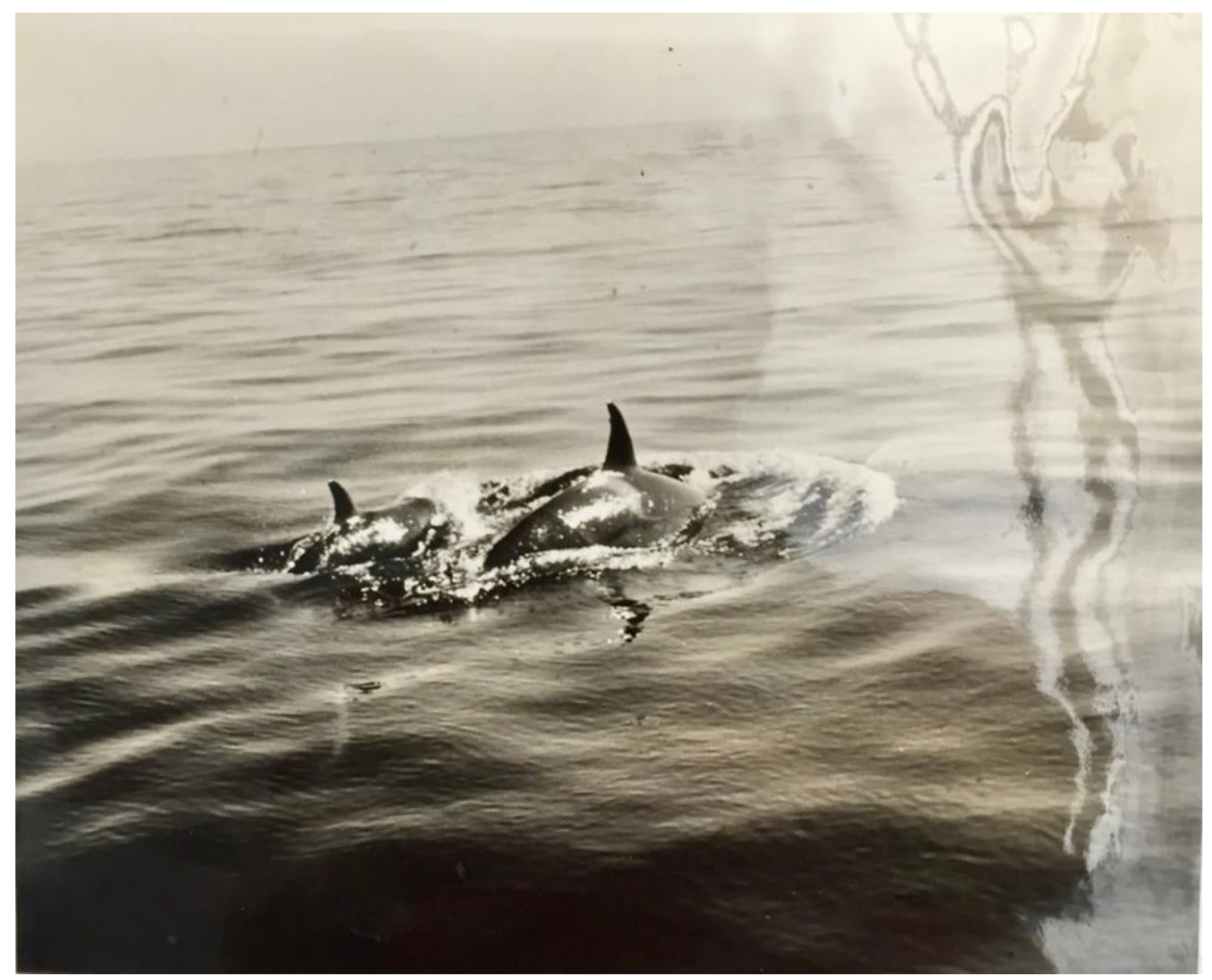

Figure 29. An adult female and infant killer whale swim past the Geronimo off San Diego in $1956 .{ }^{39}$

Marineland's willingness to attempt the capture of new and unknown cetaceans in the interest of both scientific knowledge and public spectacle-despite the possibility of failure - motivated the oceanarium's collectors to embark on what Norris called a "reconnaissance mission" to the Pacific Northwest to gather information about the possibility of capturing a killer whale. Norris believed his team could mitigate the danger involved in capturing orcas with prior preparation. Confident in their skills after landing the first open ocean capture of the pilot whale Bubbles in February 1957, Norris, Brocato and Calandrino manned the Geronimo and cruised up the California coast toward the

${ }^{39}$ Killer whale (Grampus Rectipinna) Female and young off San Diego, December 1956. Box 60, Kenneth S. Norris Papers, University of California Santa Cruz. 
Salish Sea that September. When the crew reached Seattle, they met with U.S. Fish and Wildlife mammologist Victor Scheffor at Sand Point Naval Airbase, who alleged a resident population of killer whales inhabited Puget Sound and moved around in a "regular track." If Marineland planned to capture an orca in the area, Scheffor suggested Norris reach out to the Washington state Department of Wildlife, who could monitor the collecting vessel from the air and aid the capture operation. ${ }^{40}$ The Marineland crew then moved northward to Vancouver, where they met with Ian McTaggart Cowan, head of the Zoology Department at the University of British Columbia. Cowan claimed killer whales were "extremely common" in the area, sometimes appearing in groups of up to 2,000 , congregating at the mouths of rivers to hunt salmon. Cowan also suggested the crew try sedating the whales with nicotine salicylate-a compound used to sedate deer when transporting and tagging them — to facilitate the capture operation. The Palmer Chemical Company, Cowan told Norris, was developing a hypodermic needle that could administer higher doses of the sedative when shot into an animal. The compound purportedly had no effect on the sedated animal's respiratory system and wore off within fifteen minutes. "If this works with cetaceans it would be very valuable for us," Norris noted in his field journal. ${ }^{41}$

Norris and the crew then crossed the Strait of Georgia to the town of Nanaimo on Vancouver Island to meet with marine mammologist Gordon C. Pike at the Pacific Biological Station, who conducted research on whale carcasses brought in to the Coal

\footnotetext{
40 "Kenneth S. Norris Field Notes," 329-30.

41 "Kenneth S. Norris Field Notes," 332-33. In addition to serving as a professor of vertebrate zoology, Cowan also produced nature television programs for CBC, such as Fur and Feathers and The Living Sea, which he hosted himself. For biographical information on Cowan, see Briony Penn, The Real Thing: The Natural History of Ian McTaggart Cowan (Victoria, British Columbia: Rocky Mountain Books Ltd., 2015).
} 
Harbour whaling station. He informed Norris that killer whales frequented the Alert BayDiscovery Pass region on the northern end of Vancouver Island, close to where an airport was located. The Marineland team could fly the whales directly to California from there, Pike explained, by utilizing the boom on a nearby lumber pier to lift a captured whale directly from the boat to a truck. ${ }^{42}$ On the last leg of the trip, the crew paid a visit to $\mathrm{G}$. Clifford Carl, Director of the Provincial Museum in Victoria. Carl gave Norris and Brocato a valuable piece of information from his research: killer whale calves were born around eight feet long. From this approximation, Norris judged that the crew would have to prepare for capturing a whale at least ten feet long at the minimum, in hopes that animals of that size were no longer nursing and thus had a higher chance of survival. ${ }^{43}$

Despite the killer whale's purported viciousness and willingness to attack humans, Norris approached such stories with uncertainty. Not one of the experts he met with during the reconnaissance trip could provide him with a verifiable account that orcas had attacked humans, although most cautioned him about the dangers involved in capturing the species. In a 1958 article for Natural History magazine titled "Facts and Tales About Killer Whales," Norris attempted to repudiate some of the public's common perceptions about orcas. As one of the "most fabled and feared of living creatures," the killer whale was shrouded in a "mantle of almost impenetrable myth," Norris wrote. The assertion that killer whales could break through thick pack ice to get at resting seals "must be viewed with skepticism," he cautioned, casting doubt on Herbert Ponting's forbidding tale from Captain Scott's Antarctic Terra Nova Expedition. "There seems no

42 "Kenneth S. Norris Field Notes," 334.

43 "Kenneth S. Norris Field Notes," 336. 
authenticated account of a man having been added to his fare," but the advent of recreational diving threatened the species' "clean record." "It seems probable that a diver or swimmer is not too unlike a seal to be in danger if he should meet face to face with a roving Killer whale,” Norris warned. ${ }^{44}$

While the article may have urged skin divers to give orcas their space, it also gave readers reason to believe that killer whales had more in common with humans than they might have imagined. At Twofold Bay on Australia's southeastern coast, a group of killer whales regularly assisted whalers from the town of Eden take down baleen whales until the 1920s. The crux of this reciprocal relationship, Norris explained, was that the whalemen anchored the whale carcass to the sea floor at the conclusion of a hunt, which allowed the orcas to eat the tongue and lips before towing their quarry to shore to be rendered into oil. Townspeople even recognized individual whales by name, such as Old Tom, Humpy, and Stranger. And when the beloved Old Tom died, the people of Eden cleaned his bones and proudly displayed the skeleton in a building on the main street. The relationship between humans and killer whales, Norris implied, did not have to be antagonistic. ${ }^{45}$

Norris would never see Marineland capture its first killer whale. Not long after receiving his $\mathrm{Ph} . \mathrm{D}$. from the Scripps Institute of Oceanography in 1959, he left the oceanarium to become a biology professor at the University of California, Los Angeles. But the foundational work in cetacean collection Norris accomplished with Brocato and Calandrino firmly established Marineland of the Pacific as the leading institution of

${ }^{44}$ Norris, "Facts and Tales About Killer Whales," 24-26.

${ }^{45}$ Norris, 25-26. 
dolphin and whale captivity on the West Coast. And Norris' reconnaissance trip in search of information about capturing killer whales laid the groundwork for the oceanarium's first orca capture in 1961. More than pure happenstance and luck, Marineland's accomplishment was the product of years of careful information gathering and logistical preparation for capturing a killer whale.

\section{The Capture and Captivity of Wanda}

Sometime during the third week of November 1961, locals spotted what appeared to be a whale in Newport Harbor, California. Some onlookers thought the creature might be a California gray whale that had lost its way along the species' annual fall migration route toward the mating grounds along Mexico's Baja peninsula. But the animal's glossy black color and distinctive fins marked her as a female killer whale. Newport Harbor Department officials advised boaters in small craft to "keep a safe distance," but admitted that the whale "appeared to be friendly." ${ }^{46}$ After spending the $17^{\text {th } ~ " t a k i n g ~ h e r ~ o w n ~}$ private tour of the harbor," as a reporter for the Orange County Register put itswimming circles around sailing yachts, and trying to "play tag" with small motorboatsofficials notified Marineland's curator David Brown of the whale's presence. ${ }^{47}$ Marineland staff traveled to Newport that afternoon to observe the orca newspapers had since named Wanda, and made the decision to attempt to capture the animal for the oceanarium's collection.

\footnotetext{
46 "Newport Sailors Have a Whale of a Problem," Pasadena Independent, November 17, 1961, 2.

47 "Wanda Earmarked for Capture Today," The Register, November 18, 1961, A3.
} 


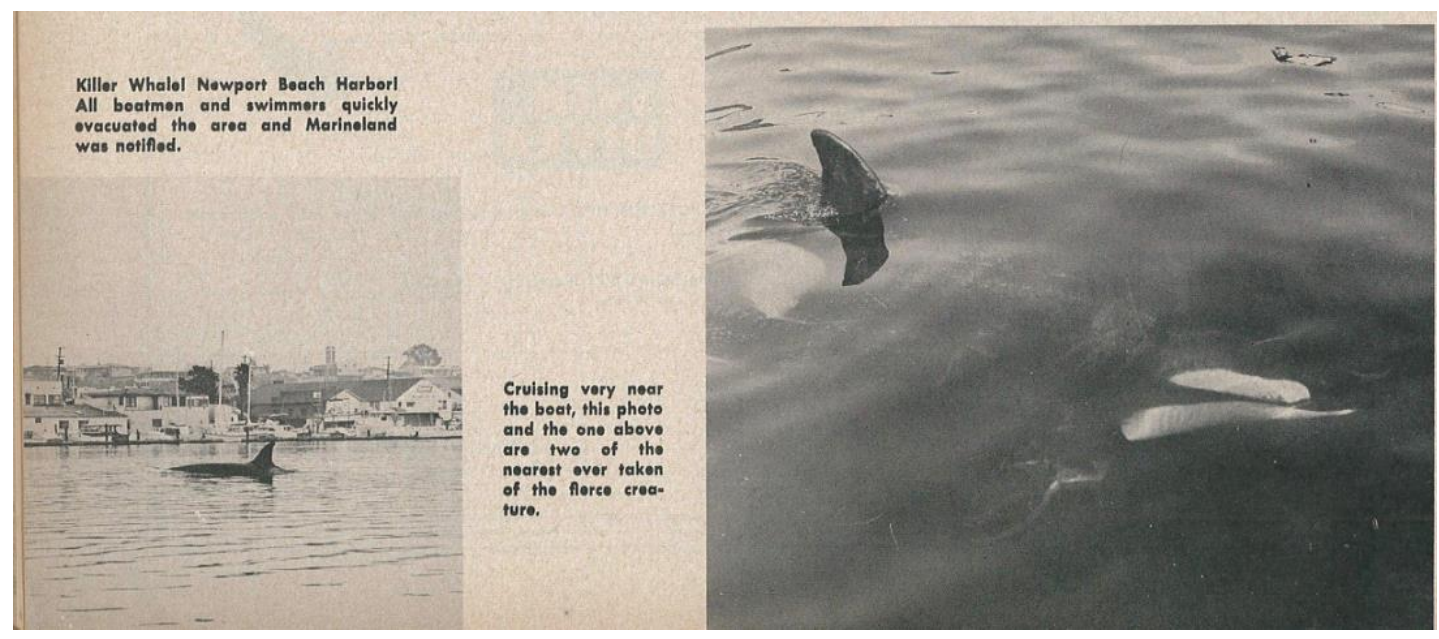

Figure 30. Wanda surfaces in the Newport Harbor turning basin. ${ }^{48}$

As the Geronimo chugged into the harbor at 6:30 the next morning, Brocato and Calandrino found the whale still swimming in the turning basin and put the operation into motion. The collectors soon realized that using the porpoise snare they employed to capture dolphins and pilot whales was impossible because of Wanda's erratic movements and the cloudy harbor water, so they opted instead for a substantial 1200-foot-long, 75foot-deep net. Nearby streets became clogged with automobile traffic as thousands of spectators gathered around the shore and crowded the harbor in small craft to catch a glimpse of the thrilling spectacle. ${ }^{49}$ After the men encircled the whale with the net, she broke through the mesh and escaped, loudly slapping her tail flukes on the surface water. Brocato and Calandrino repaired the net and tried again, but Brown observed that "the animal appeared to anticipate the intentions of the men," often resurfacing 50 yards away

\footnotetext{
${ }^{48}$ Don Siverts, "Killer Whale!,” Skin Diver Magazine, March 1962, 44.

49 "5,000 See Killer Whale Captured at Newport," A6.
} 
from the boat. Each time Wanda evaded the net, onlookers cheered in support. ${ }^{50}$ When Calandrino joined some of the crewmembers in the skiff to help, he lost his footing and plunged into the water. "For the short distance back to the boat, he probably broke all swimming records," the Long Beach Independent Press-Telegram quipped, despite being weighed down by his clothing and heavy hip boots. ${ }^{51}$ For a time, it seemed Wanda had outsmarted Marineland's experienced collections team.

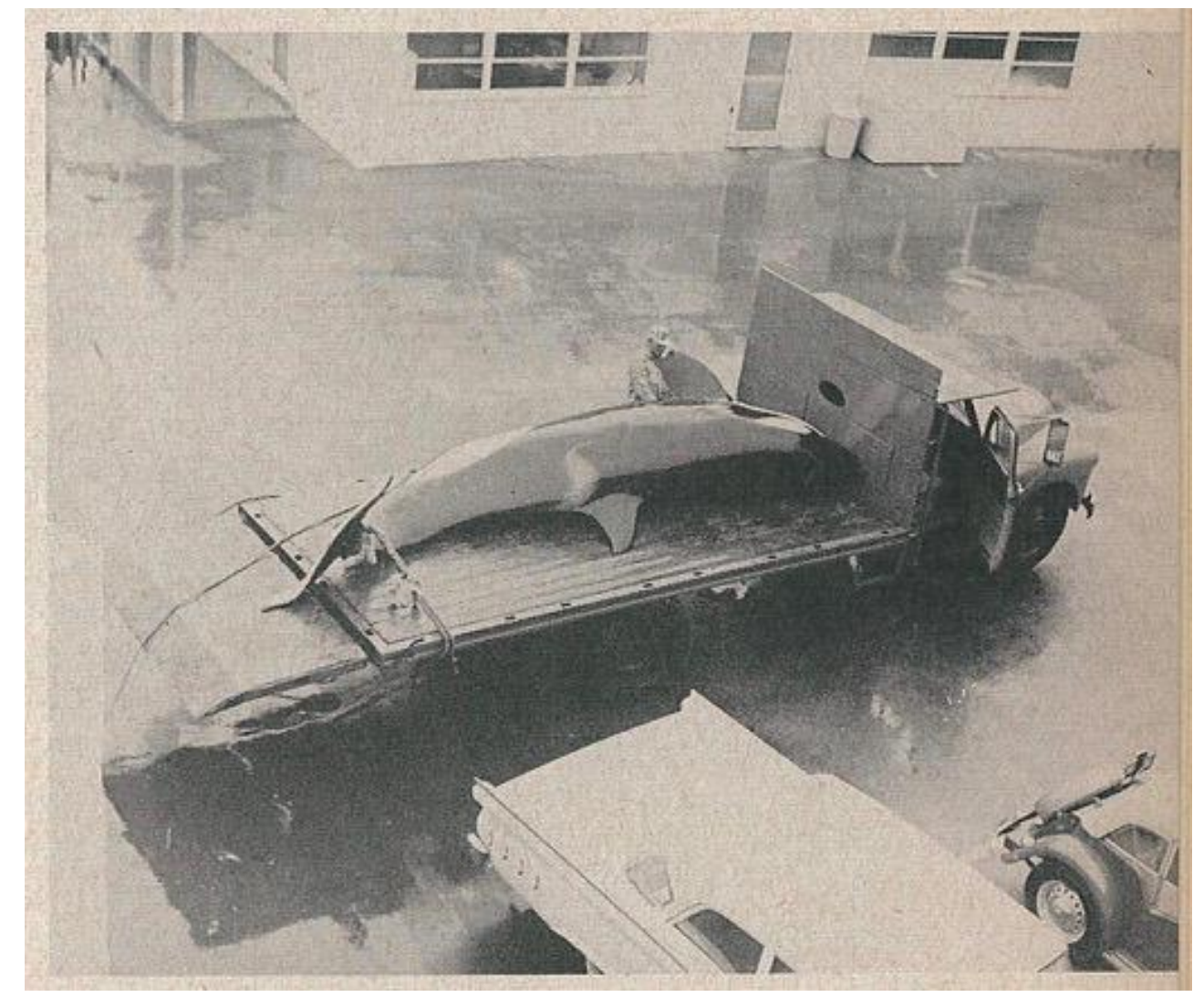

Figure 31. Wanda is placed on a flatbed truck for transportation to Marineland. ${ }^{52}$

\footnotetext{
${ }^{50}$ David K. Caldwell and David H. Brown, "Tooth Wear as a Correlate of Described Feeding Behavior by the Killer Whale, with Notes on a Captive Specimen," Bulletin of the Southern California Academy of Sciences 63, no. 3 (1964): 137.

${ }^{51}$ Bob Geivet, "Killer Whale Netted in Newport Harbor," Independent Press-Telegram, November 19, $1961,1$.

${ }^{52}$ Siverts, "Killer Whale!," 45.
} 
But as the afternoon dragged on, the whale began to tire. At 3:15, roughly nine hours after the capture operation began, the crew had secured Wanda alongside the hull of the Geronimo. After pulling a deflated rubber raft underneath the whale and inflating it, the collectors tugged the 17-foot whale to the Lyon Orval Docking facilities on West Coast Highway, where they loaded Wanda onto a flatbed truck, covered her in wet blankets, and drove her to Marineland. ${ }^{53}$ By 10:00 that night, oceanarium staff had hoisted Wanda into the 100-foot long, 19-foot deep oval fish tank display. Despite telling the Los Angeles Times that killer whales were "the most vicious animal on land or sea," Marineland general manager William Monahan was in high spirits. ${ }^{54}$ The whale's "mistake" of swimming into the harbor, Monahan exclaimed, is "one of the greatest things that could ever have happened to us." ${ }^{55}$ As the world's first live killer whale capture, "there is no way to put a monetary value on her," he boasted. ${ }^{56}$ David Brown proudly echoed Monahan's sentiments: "Now we have everything."

\footnotetext{
${ }_{53}^{53}$ Don Angel, "Killer Whale Captured Alive at Newport," The Register, November 19, 1961, A1. 54 "5,000 See Killer Whale Captured at Newport," A6.

${ }^{55}$ Bill Dunlevy, "Wanda the Whale Takes Residence at Marineland," Independent, November 20, 1961, 10.

56 "Killer Whale in New Home at Marineland," Los Angeles Times, November 20, 1961, B1.

${ }^{57}$ Dunlevy, "Wanda the Whale Takes Residence at Marineland," 10.
} 


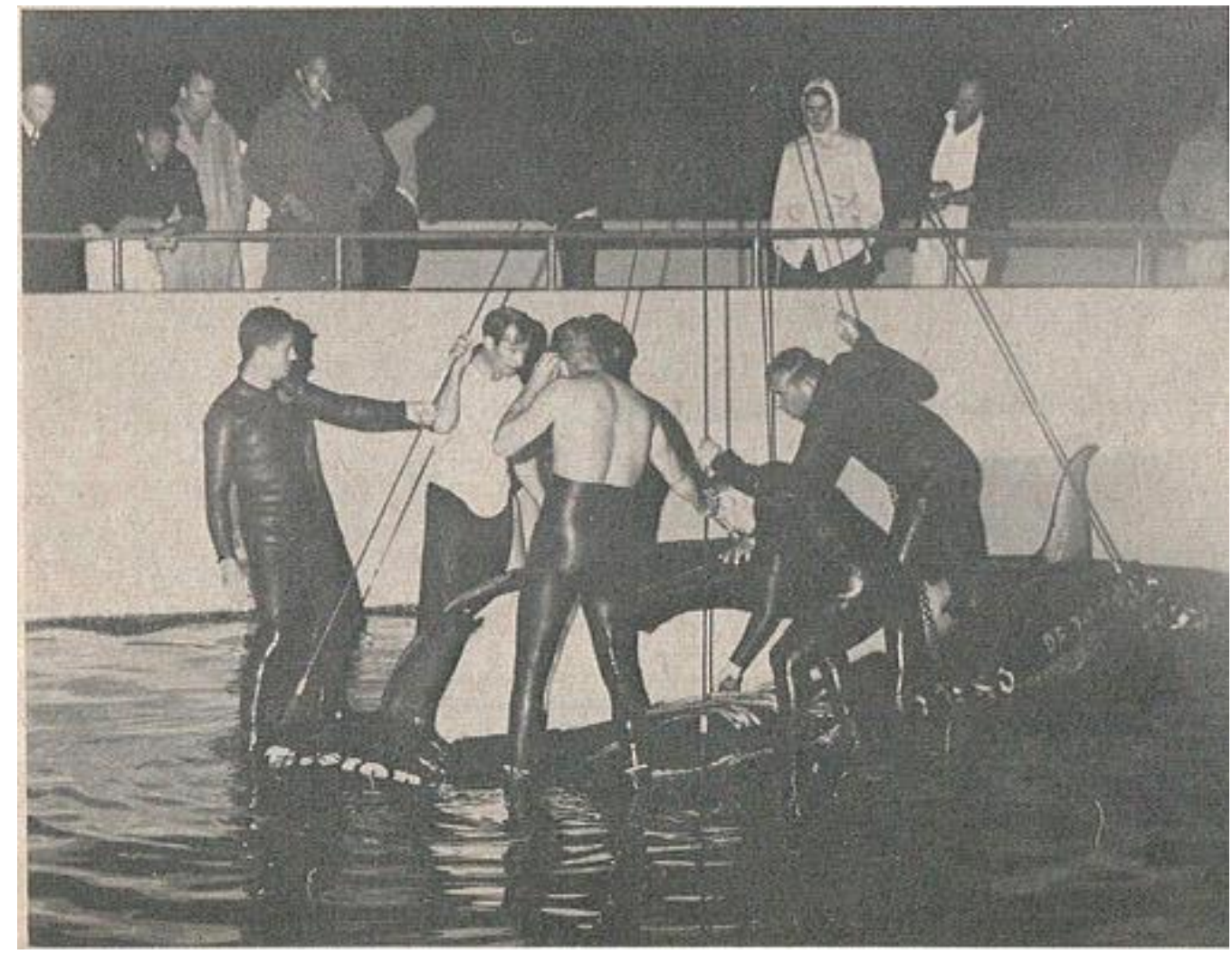

Figure 32. Marineland staff place Wanda into the oval display tank. ${ }^{58}$

As crowds of visitors gathered around the tank, Wanda was having a difficult time adjusting to the new enclosed environment. "She rammed her nose into the wall, but after that, she knew enough to circle 'round and 'round," Brown told the papers. ${ }^{59}$ The whale understood other creatures in the tank to be prey, killing an ocean sunfish (Mola mola) that shared the pool. But Wanda did not consume the fish, so caretakers tried feeding her by hand. ${ }^{60}$ "Right now...we're slapping her on the nose with a bonito tied on a long cord, hoping she'll get mad at it and bite it, thus learning she can obtain hand-fed food," Brown

\footnotetext{
${ }^{58}$ Siverts, "Killer Whale!," 45.

${ }^{59}$ Dunlevy, "Wanda the Whale Takes Residence at Marineland," 10.

${ }^{60}$ Caldwell and Brown, "Tooth Wear as a Correlate of Described Feeding Behavior by the Killer Whale, with Notes on a Captive Specimen," 137.
} 
informed the Long Beach Independent. ${ }^{61}$ Throughout the day, staff made numerous attempts to feed Wanda, but all proved to be in vain. Occasionally, the whale would try to bite the fish, but never ate a thing. And when Wanda opened her mouth, Brown noticed that nearly all of her teeth were extremely worn, most of them even with the gum line. Early the next morning, circumstances took a turn for the worst. The "whale became violent," Brown explained in a published report; she repeatedly rammed herself against the tank wall, swam into the flume way, convulsed, and died. ${ }^{62}$

Staff removed Wanda's body from the pool and veterinary pathologists from the Los Angeles County Livestock Department performed a necropsy. The results revealed that up until the time of her death, the whale was suffering from numerous ailments. Her first and second stomach compartments were infested with nematode worms, her right jaw was fractured from a prior traumatic injury, and her heart and major blood vessels showed evidence of advanced atherosclerosis (cardiovascular disease). The direct cause of Wanda's death, the pathologists determined, was attributed to an intestinal infection and pneumonia. Additionally, the experts concluded, "the great stress of experienced by the animal during capture and confinement contributed to the pathological condition." Brown sent a tooth sample to biologist David E. Sergeant of the Fisheries Research Board of Canada in Montreal to determine the age of the whale. Sergeant, an authority on age estimation in marine mammals, counted the dentine layers from the Newport specimen and determined the whale was "certainly old," with an age of at least 25 years.

\footnotetext{
${ }^{61}$ Dunlevy, "Wanda the Whale Takes Residence at Marineland," 10.

${ }^{62}$ Caldwell and Brown, "Tooth Wear as a Correlate of Described Feeding Behavior by the Killer Whale, with Notes on a Captive Specimen," 137-38; "Killer Whale Dies in Tank," The Register, November 20, 1961, A1; "Killer Whale Succumbs," Palos Verdes News, November 22, 1961, 1.
} 
In a paper published with marine mammal researcher David K. Caldwell, Brown

attributed the excessive tooth wear to also be an indicator of the animal's advanced age. ${ }^{63}$

The killer whale Marineland collectors captured at Newport was ill, likely disoriented, and near death. But the oceanarium's brief experience exhibiting Wanda proved that the sight of an orca fascinated people. Newspapers estimated anywhere from 5,000 to 8,000 came to Newport Harbor to view the capture, and still more visited Marineland to see the whale the next day. An animal with this kind of draw was worth going after again. For less than 36 hours, Marineland had achieved what no aquarium had done before, and proved that killer whales could indeed be captured alive. And Brocato and Calandrino were already preparing for a second attempt.

\section{The Aftermath}

A little less than one year after capturing the Newport orca, Marineland collectors again turned their sights to the Salish Sea in search of killer whales. In September 1962, while hunting in the Haro Strait region between San Juan Island and Vancouver Island in Puget Sound, Brocato and Calandrino set their eyes on their target. Two adult killer whales - one male and one female — pursuing a harbor porpoise (Phocoena phocoena) swam swiftly toward the Geronimo. The porpoise used the boat for cover, causing the female orca to chase the prey around the vessel. With little time to act, Calandrino

${ }^{63}$ Caldwell and Brown, "Tooth Wear as a Correlate of Described Feeding Behavior by the Killer Whale, with Notes on a Captive Specimen," 136-39. Sergeant published a paper in 1959 that included a study of the dentine growth layers in captive-born bottlenose dolphins at Marine Studios, Florida. David E. Sergeant, "Age Determination in Odontocete Whales from Dentinal Growth Layers," Norsk HvalfangstTidende 48, no. 6 (June 1959): 273-88. Counting dentine growth layers remains an important method of estimating the age of toothed (odontocete) whales. Aleta A. Hohn, "Age Estimation," in Encyclopedia of Marine Mammals, ed. William F. Perrin, Bernd Würsig, and J. G. M. Thewissen, 2nd ed. (New York: Academic Press, 2009), 11-17. 
manned the bowsprit and lassoed the female with the breakaway hoop net. "We had her," Brocato remembered, "but then everything started to go wrong." The female dove underneath the boat, causing the heavy nylon line to get tangled in the propeller. After running the length of the line, the female began to emit high-pitched, piercing screams. Brocato took the cries to be a distress call, because he reported that the male almost immediately "zeroed in on the female as if by radar." Swimming in synch with each other, the pair then charged the boat three times, striking the hull with their flukes. Fearing for the safety of the crew, Brocato grabbed his .375-magnum rifle and shot the male once, who quickly disappeared. He then fired at the female, who endured 10 bullets before her death. ${ }^{64}$ "We had to shoot it to keep from being smashed to pieces," Calandrino recalled. ${ }^{65}$ When the crew got the rope untangled from the propeller, they towed the female whale's carcass to the nearby town of Bellingham to be weighed and measured. After taking the teeth as souvenirs, Brocato took the carcass to a processing plant where it was rendered for dog food. ${ }^{66}$

Marineland's failed collection mission in Puget Sound was the last time the park would ever try to capture a killer whale. However, it was not long before another aquarium achieved what Marineland had not. In 1964, the director of the Vancouver Aquarium Murray Newman commission artist Samuel Burich to create a life-sized sculpture of a killer whale to hang from the ceiling of the aquarium's new British Columbia Hall exhibit. In order to ensure the accuracy of the model, Newman hired local

\footnotetext{
${ }^{64}$ Erich Hoyt, Orca: The Whale Called Killer, Fourth (Firefly Books Ltd., 1990), 18-19; Caldwell and Caldwell, "Epimeletic (Care-Giving) Behavior in Cetacea," 771-72.

${ }^{65}$ Timothy Branning, "Whales: He Brought 'Em Back Alive," Independent Press-Telegram, August 24, 1974, 23.

${ }^{66}$ Hoyt, Orca: The Whale Called Killer, 19.
} 
fisherman and "experienced harpoonist" Ronald Sparrow to slay a live animal so measurements, photographs, and plaster molds could be taken of the whale. Burich and Sparrow stationed a harpoon gun at East Point on Saturna Island, and after two months of waiting, finally harpooned an orca in July. But the strike did not land a killing blow and incredibly the whale survived. Newman, who was reluctant to execute the animal, had his team tow the whale back to Vancouver's Burrard Drydock and place it in a sea pen. Thinking the whale was female, Newman named her Moby Doll. ${ }^{67}$

Almost overnight, Moby Doll became an international celebrity, and attracted nearly 20,000 people to the docks to glimpse the spectacle. Thousands of miles away in Los Angeles, Marineland of the Pacific moved to capitalize on the public's interest in Moby. Curator David Brown flew to Vancouver and offered Newman $\$ 20,000$ for the whale. A short bidding war with other local aquariums raised Marineland's offer to $\$ 25,000$. "Marineland would top anyone’s offer," Newman remembered Brown telling him. But Newman was not interested in selling Moby and refused. Inadvertently, Marineland had set the asking price for the species. For Newman, the offer foretold the further commodification of orca bodies: "This species' age of innocence was over...we had unwittingly opened the way to a new kind of commercialism," he later wrote. ${ }^{68}$ Moby Doll, who turned out to be a young male, died after 87 days in the polluted harbor water, but it was not long before Seattle Marine Aquarium owner Ted Griffin purchased an adult

\footnotetext{
${ }^{67}$ Newman, Life in a Fishbowl: Confessions of an Aquarium Director, 83-89; Murray A. Newman and Patrick L. McGreer, “A Killer Whale (Orcinus Orca) at Vancouver Aquarium," International Zoo Yearbook 6 (1966): 257-59.

${ }^{68}$ Newman, Life in a Fishbowl: Confessions of an Aquarium Director, 89-93. For a history of Moby Doll, see Mark Leiren-Young, The Killer Whale Who Changed the World (Vancouver, Canada: Greystone Books, 2016).
} 
male orca that fishermen on the island of Namu, British Columbia, accidently caught in a salmon net. Griffin named the whale after the capture location and displayed him in a floating pen near the aquarium. Although Namu survived only a year in captivity, his gentle temperament permitted divers to swim with him and ride on his back, inspiring the 1966 United Artists film Namu, the Killer Whale, the first feature film about an orca. Namu, which was produced by Ivan Tors (who also produced the 1963 dolphin blockbuster Flipper) attempted to dispel many of the negative myths about killer whales by portraying Namu as a friendly human companion. ${ }^{69}$ In the eyes of the public, killer whales were no longer ferocious sea monsters. Public display had transformed the species into an affectionate animal celebrity.

\section{Conclusion}

As the decade progressed and more aquariums began to acquire killer whales, public memory of Marineland's 1961 capture of Wanda faded. However, Marineland memorialized its achievement by constructing a life-sized replica of Wanda's body and displaying it at the park. Describing the model as one of the "special side features" visitors could see at Marineland, a promotional booklet proclaimed:

The killer whale, in advanced old age and suffering several terminal ailments, survived a short time when put into the oval tank at Marineland. But its capture demonstrated that one of its kind possibly could be taken alive in the open sea and brought ashore to be kept on love display indefinitely. The killer whale is reputed to be the most vicious beast ever to inhabit the land or sea. ${ }^{70}$

\footnotetext{
${ }^{69}$ Laslo Benedek, Namu, the Killer Whale (United Artists, 1966). For Griffin's account of his experiences with Namu, see Edward I. Griffin, "Making Friends With a Killer Whale," National Geographic, March 1966; Ted Griffin, Namu: Quest for the Killer Whale (Seattle, Washington: Gryphon West Publishers, 1982).

${ }^{70}$ Marineland of the Pacific Information Booklet (Palos Verdes, California: Oceanarium, Inc., 1964), 18.
} 
While a reproduction of her body was on display at Marineland, curators transferred her skull to the Los Angeles County Natural History Museum, where it remains to this day in an offsite storage facility. In 2006, genetic analysis of Wanda's bones revealed that she was part of the offshore ecotype of Northern Pacific killer whales that range from Southern California to Alaska. Subsequent studies found that extreme tooth wear is common in offshore killer whales because their diet consists primarily of pelagic sharks. While shark skin may appear visually smooth, the presence of hardened dermal denticles (placoid scales) makes the skin highly abrasive, likely causing the dental wear exhibited in the whales that hunt sharks. ${ }^{71}$

\footnotetext{
${ }^{71}$ Phillip A. Morin et al., "Genetic Analysis of Killer Whale (Orcinus Orca) Historical Bone and Tooth Samples to Identify Western U.S. Ecotypes,” Marine Mammal Science 22, no. 4 (October 2006): 897-909; Marilyn E. Dahlheim et al., "Eastern Temperate North Pacific Offshore Killer Whales (Orcinus Orca): Occurrence, Movements, and Insights into Feeding Ecology," Marine Mammal Science 24, no. 3 (July 2008): 719-29; John K. B. Ford et al., "Shark Predation and Tooth Wear in a Population of Northeastern Pacific Killer Whales," Aquatic Biology 11 (2011): 213-24.
} 


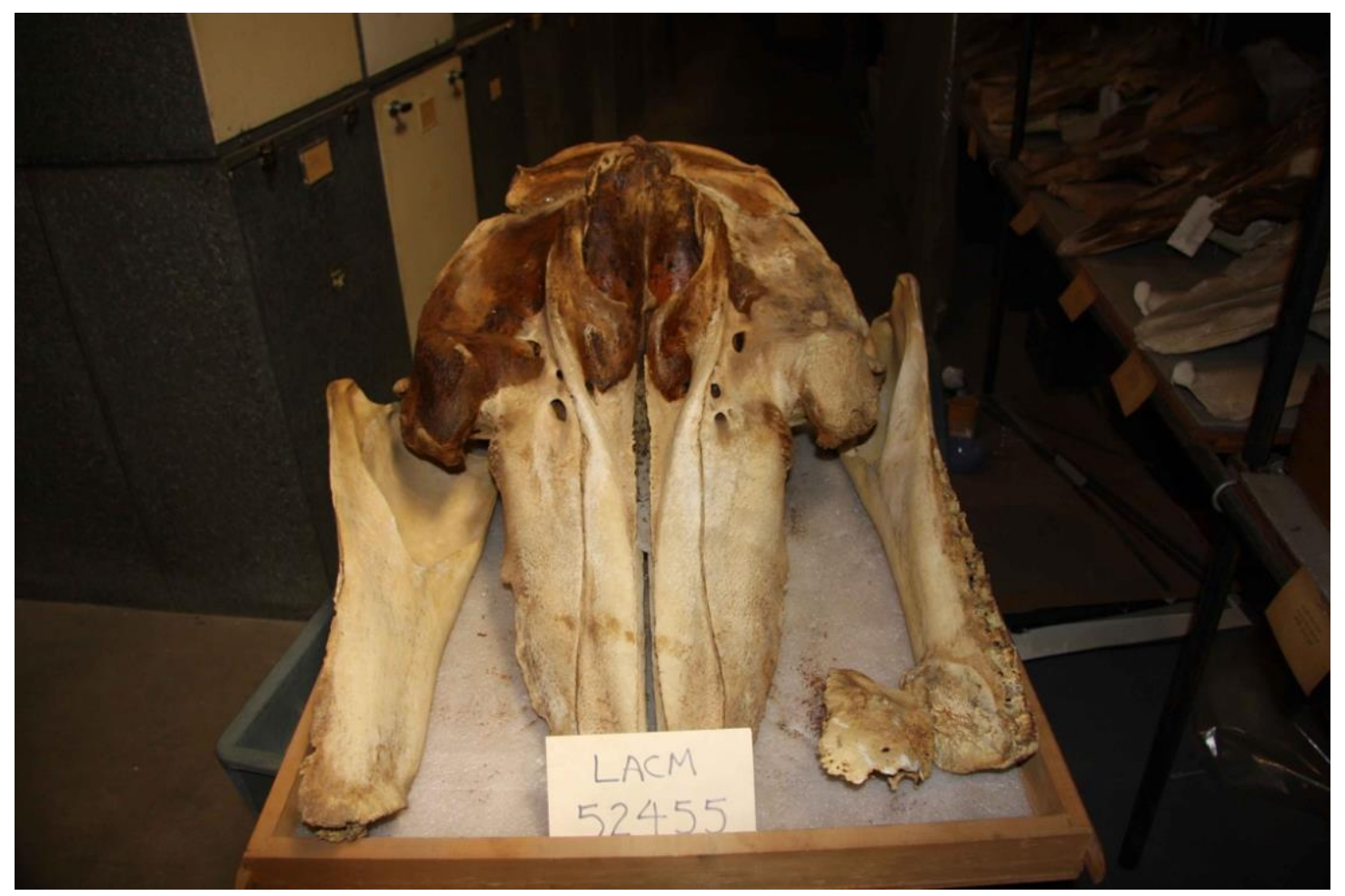

Figure 33. Wanda's skull at an offsite LA County Natural History Museum storage facility. Photo courtesy of Jim Dines.

Despite their considerable experience in cetacean collection, Brocato and Calandrino never ended up capturing another killer whale for Marineland. Instead, the park's management opted to buy them. A few years after charismatic killer whale performers like Namu and Shamu became household names through appearances at marine parks, on film, and in newspapers and magazines, Marineland purchased their first killer whale in 1967 from fishermen in British Columbia. Nevertheless, Marineland's early bids to display killer whales were a critical moment in the history of captive orcas. The park's ambition, willingness to experiment and take risks, demonstrated to other aquariums that capturing killer whales-although difficult and potentially dangerous — was a possibility. 


\section{Epilogue}

\section{Cetacean Entertainment in the Wake of Blackfish}

On November 16, 2016, Palos Verdes' Daily Breeze newspaper reported that the 26-foot statue of Bubbles the whale, the iconic symbol of Marineland of Pacific that welcomed guests outside the park's entrance for decades, would soon return to the Peninsula. The fiberglass likeness of the pilot whale performer had been relegated by city officials to a maintenance yard shortly after the oceanarium closed in 1987. Sentimental locals, spurred by news of Bubbles death at SeaWorld's San Diego location that summer, amassed over 1,200 signatures on a Change.org petition to restore the statue near where Marineland once stood. The City Council agreed and approved a plan to remount outside the Point Vicente Interpretive Center, a small local history museum and whale watching station on the Palos Verdes coast. ${ }^{1}$

The public lament over Bubbles' death at SeaWorld conjured up memories of the charismatic whale's performances at Marineland. In 1987, Bubbles and the rest of Marineland's cetaceans were transferred to SeaWorld San Diego after the publishing company Harcourt Brace Jovanovich—-then owner of SeaWorld— purchased Marineland and closed the park. The Bubbles that park visitors remembered, however, may not have been the original whale that inspired the statue. Marineland collectors captured the first Bubbles in February of 1957, but she lived for only three years. Following a common practice in oceanariums at the time, if the individual animal died, the park simply

\footnotetext{
${ }^{1}$ Cynthia Washicko, "Iconic Statue of Marineland's Bubbles the Whale Will Return to Palos Verdes Peninsula," Daily Breeze, November 16, 2016, https://www.dailybreeze.com/2016/11/16/iconic-statue-ofmarinelands-bubbles-the-whale-will-return-to-palos-verdes-peninsula/.
} 
replaced the performer with another of the same species. This way the animal star (and the show) lived on. The Bubbles that died in 2016 was captured by Marineland in 1966, and SeaWorld caretakers estimated the animal was in her mid-fifties when she died. ${ }^{2}$

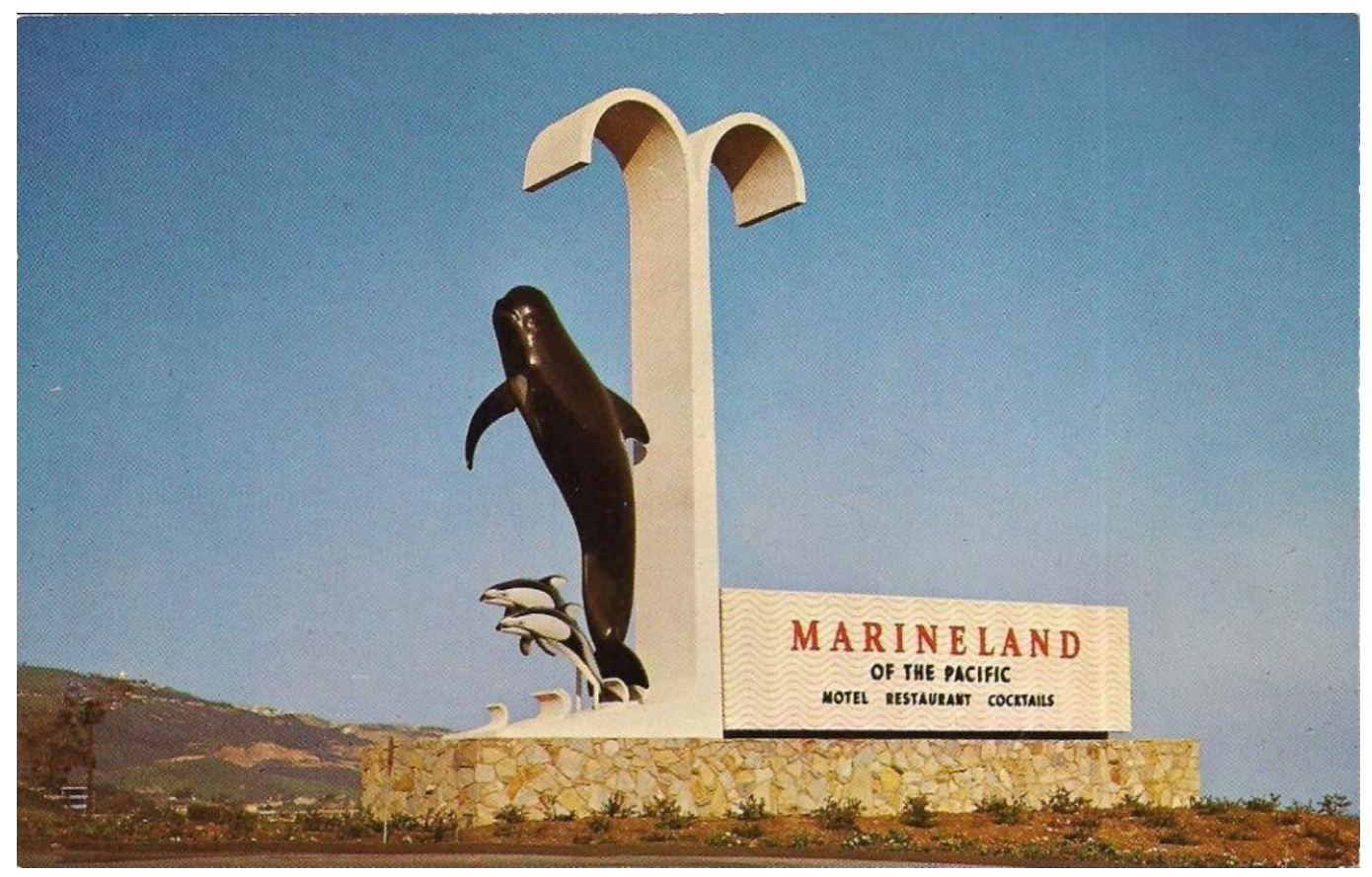

Figure 34. Marineland's entrance sign, featuring Bubbles the whale flanked by two Pacific whitesided dolphins. ${ }^{3}$

The plan to restore the prized symbol of one of the marine mammal entertainment industry's early pioneers likewise attracted public criticism. Gabriela Cowperthwaite's influential 2013 documentary Blackfish, which drew attention to the consequences of keeping killer whales in captivity and to the dangers they posed to their trainers, was still fresh in many readers' minds. ${ }^{4}$ As the article made its rounds across online social media

\footnotetext{
2 "Bubbles, Pilot Whale at SeaWorld San Diego, Dies," Orange County Register, June 11, 2016, https://www.ocregister.com/2016/06/11/bubbles-pilot-whale-at-seaworld-san-diego-dies/.

${ }^{3}$ George E. Watson, "Marineland of the Pacific Entrance Sign Postcard" (Golden West Color Card Company, undated), Author's personal collection.

${ }^{4}$ Gabriela Cowperthwaite, Blackfish (Magnolia Pictures, 2013).
} 
platforms, some readers expressed their disapproval of the restoration plan. Earlier that year when news of Bubbles' death broke, critics on social media began using the hashtags \#CaptivityKills and \#EmptyTheTanks to connect the death to the broader animal rights debate against SeaWorld parks. Although criticism of dolphin and whale captivity had been a topic of public discourse since the late 1980s, Blackfish was widely available to younger viewers through the video streaming service Netflix, which exposed the film's anti-captivity message to a new generation. And SeaWorld, which had become the dominant face of the industry in the previous decades, felt the pressure. In March 2016, SeaWorld announced plans to convert its theatrical killer whale shows into "natural orca encounters" with an educational focus and end its killer whale breeding program. ${ }^{5}$ The park's decision came out ahead of California's Orca Protection and Safety Act, signed into law by Governor Jerry Brown in September of that year, which banned captive orca breeding and the use of orcas in non-educational shows statewide. ${ }^{6}$

The producers of Blackfish chose to focus primarily on the human deaths caused by the male orca Tilikum, a whale SeaWorld acquired from the Canadian park Sealand of the Pacific in 1992. The film's messaging was so powerful because it linked the whale's aggression directly to inadequate captive conditions and the psychological stress caused by performing in shows. By approaching the issue from both a human-centric and a whale-centric point of view, Blackfish effectively defined the parameters of the debate,

\footnotetext{
5 "Press Release: SeaWorld Announces Last Generation of Orcas in Its Care" (SeaWorld Entertainment, Inc., March 17, 2016), http://www.seaworldinvestors.com/news-releases/news-releasedetails/2016/SeaWorld-Announces-Last-Generation-Of-Orcas-In-Its-Care/default.aspx. ${ }^{6}$ Kristin Hugo, "Orca Shows and Breeding Banned in California," National Geographic, September 14, 2016, https://news.nationalgeographic.com/2016/09/california-bans-SeaWorld-orca-breedingentertainment/.
} 
appealing to advocates of both workplace safety and animal welfare. Not only did captive orcas endanger human trainers, keeping these self-aware, highly social, and intelligent marine predators in artificial, confined spaces to perform tricks was deeply immoral.

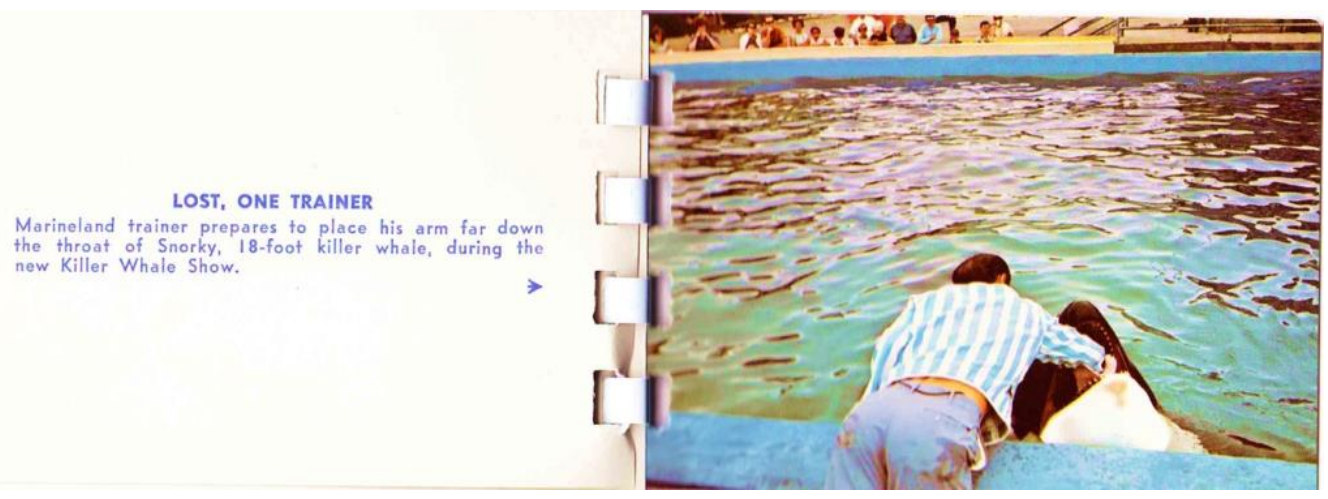

Figure 35. Early captors believed killer whales posed little threat to humans. A 1969 Marineland picture booklet joked that a trainer had been eaten by a whale. ${ }^{7}$

Yet, the film that turned a generation of viewers against the captivity of whales and dolphins did not mention the role played by SeaWorld's West Coast predecessor, Marineland of the Pacific, in the rise of delphinid entertainment. In many respects, Marineland provided the template for SeaWorld's success. In the first decade of its existence, Marineland cultivated public interest in large cetacean performers like pilot whales Bubbles and Bimbo. It established iconic dolphin and whale characters and imbued them with pet-like temperaments and genial personalities that SeaWorld replicated with cetacean stars like Shamu. And Marineland was the first park to successfully capture the coveted killer whale, an animal whose popularity would later transform SeaWorld into the leading oceanarium facility in North America. Marineland's

${ }^{7}$ Marineland of the Pacific Miniature Picture Booklet (New York: Dexter Press, 1969). 
first curator Kenneth Norris was even a design consultant and founding member of SeaWorld's original San Diego location, which opened in 1964.
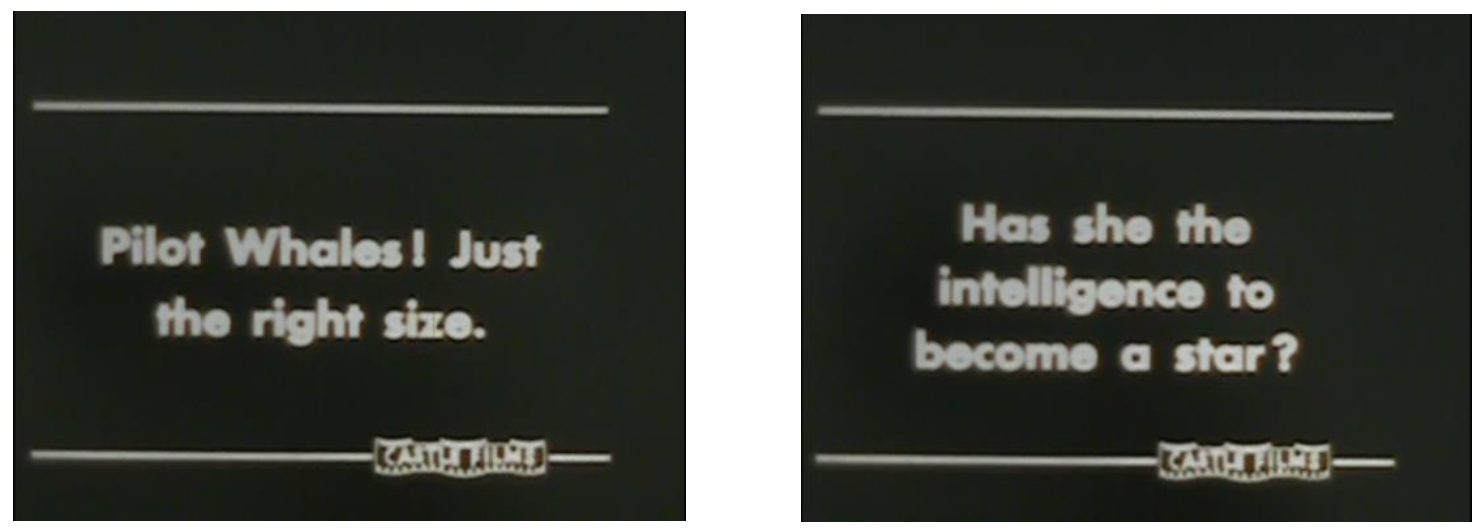

Figure 36. Title cards from the 1960 silent short film The Whale That Became a Star, produced by Oceanarium, Inc. ${ }^{8}$

Nevertheless, Blackfish raised important concerns about the well-being of cetaceans kept in marine parks. Early efforts to exhibit delphinids were defined by unsuccessful (and at times violent) capture operations, ineffective attempts to control aggressive or sexual animals, and untested veterinary care methods. The survival rate of captive dolphins and whales was low because caretakers simply did not possess adequate knowledge to care for them. In a period where no regulations restricted the live capture of small cetaceans, oceanariums like Marineland were free to develop capture technologies through trial and error. The Marine Mammal Protection Act, passed by the United States Congress in 1972, stipulated that cetaceans could not be captured in U.S. waters for public display without a permit, which effectively provided a record of all dolphins and

\footnotetext{
${ }^{8}$ The Whale That Became a Star (Castle Films, 1960).
} 
whales collected by marine parks following the law. The number of animals taken by marine parks and aquariums before the law, however, is mostly unknown.

Modern animal welfare advocates are quick to denounce the practices of early oceanariums like Marineland. As perceptions of cetaceans evolved in the latter half of the twentieth century, circus-like performance routines now appear to denigrate the animals rather than inspire affection for them. Tales of capturing dolphins and whales read more like traumatic horror stories rather than genuine efforts to learn more about mysterious marine inhabitants. Experimental husbandry methods and veterinary care look like sloppiness at best (and animal torment at worst), rather than the work of caretakers illprepared to deal with creatures the scientific community knew little about. In the eyes of Marineland staff, delphinids occupied an ambiguous and at times contradictory moral space that wavered between anthropomorphism and indifference. This, critics claim, is the dark history of an industry that was unethical from its very beginnings.

As public debates about cetacean captivity move forward, it is crucial to understand the context in which early oceanariums operated and how these institutions, by exhibiting live dolphins and whales, transformed public perceptions of them. Prior to widespread public display, few North Americans would have expressed moral outrage that large-scale tuna fishing operations killed hundreds of thousands of dolphins every year, or that the whaling industry was gradually decimating the world's remaining populations of large whales. Oceanarium exhibition, through live performances and on film, allowed audiences to form a connection with dolphins and whales that eventually led to their legal protection and celebrity status. The majestic, intelligent, emotional 
creatures we know today might never have existed without the visibility and scientific research oceanariums like Marineland provided. 

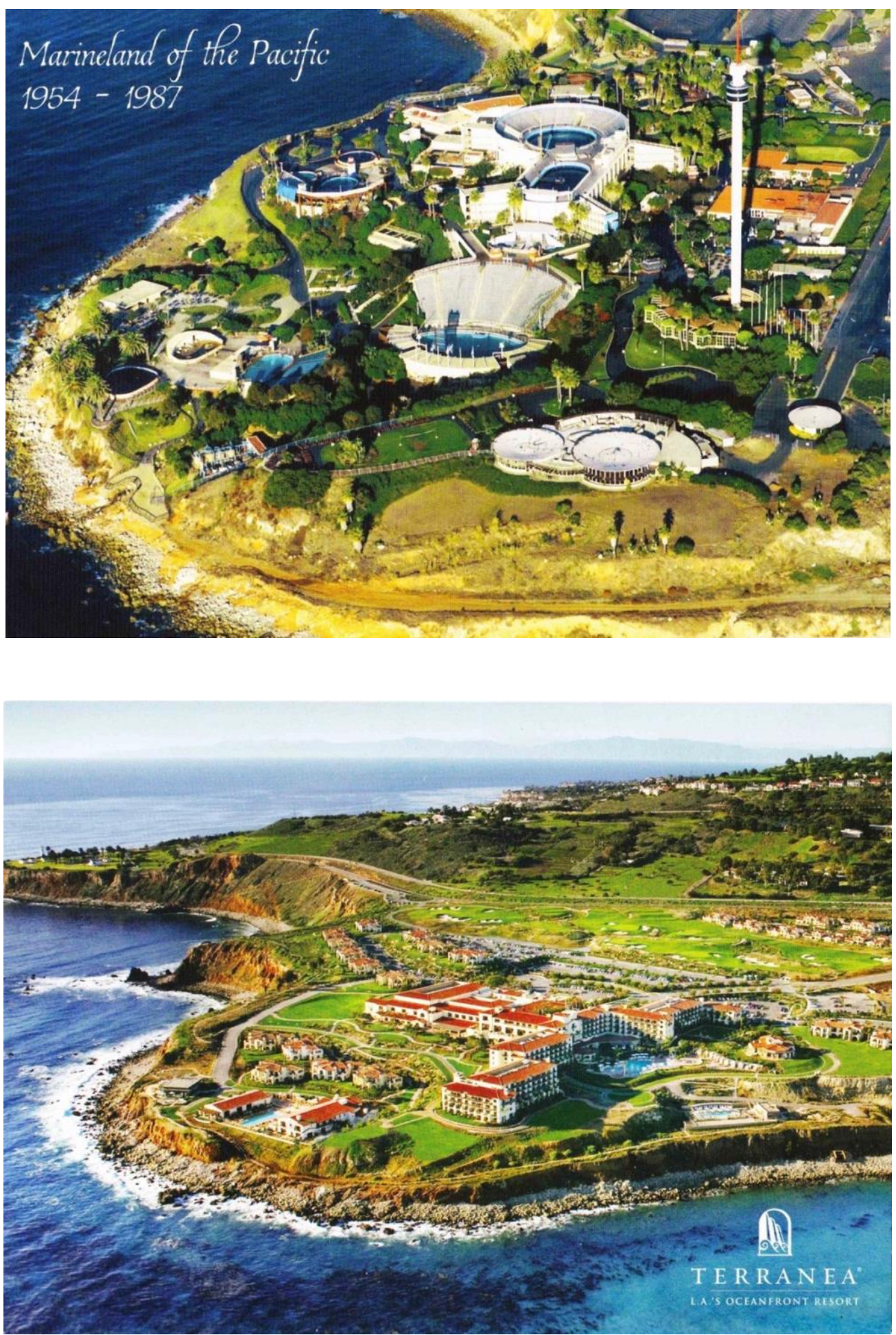

Figure 37. An aerial view of Marineland, shortly before it closed in 1987 (top) and a 2016 photograph of the resort that now occupies the same location. ${ }^{9}$

9 “Terranea Resort Marineland Heritage Card” (Destination Hotels \& Resorts, n.d.), Author's personal collection. 


\section{Bibliography}

"4 Jumping Porpoises Flown Here from Florida.” Los Angeles Times. September 15, 1954.

“5,000 See Killer Whale Captured at Newport.” Los Angeles Times. November 19, 1961.

"A Battle Between Leviathans." The Marin Journal. October 11, 1894.

"A Competitor for the 'Beef Trust."” The Southern Planter, March 1911.

"A Whale of a Business." Frontline. PBS, November 11, 1997.

Adams, John E. "Shore Whaling in St. Vincent Island, West Indies." Caribbean Quarterly 19, no. 4 (December 1973): 42-50.

"Alice in Marineland Honored at Tea." Palos Verdes News. July 1, 1954.

Allen, Winfred E. "Wolves of the Sea." The Sacramento Union. July 30, 1922.

Ammon, Francesca Russello. "Unearthing Benny the Bulldozer: The Culture of Clearance in Postwar Children's Books." Technology and Culture 53, no. 2 (April 2012): 306-36.

Andrews, Roy Chapman. Whale Hunting with Gun and Camera. New York: D. Appleton and Company, 1916.

Angel, Don. "Killer Whale Captured Alive at Newport." The Register. November 19, 1961.

"Antarctic Perils Shown on Screen: Moving Pictures of Captain Scott's South Pole Expedition at Clunie Two Days." The Sacramento Union. December 12, 1913.

“Appetite.” In The Merck Veterinary Manual, 105-6. Rahway, New Jersey: Merck \& Co., Inc., 1955.

Asper, Edward D. "Techniques of Live Capture of Smaller Cetacea." Journal of the Fisheries Research Board of Canada 32, no. 7 (1975): 1191-96.

Beebe, C. William. "Midgets and Giants of the Animal World." New York Tribune. October 6, 1907.

Benedek, Laslo. Namu, the Killer Whale. United Artists, 1966.

Bhargava, Michael. "Of Otters and Orcas: Marine Mammals and Legal Regimes in the North Pacific." Ecology Law Quarterly 32, no. 4 (2005): 939-88.

"Bologna of Porpoise and Beef the Latest." Pittsburgh Daily Post. March 14, 1910. Bonnaterre, Pierre Joseph. Tableau Encyclopédique et Méthodique Des Trois Régnes de La Nature: Cetologie. Vol. 126. Paris: Charles Joseph Panckoucke, 1789.

"Boston Aquarial Gardens." Barre Gazette. June 21, 1861.

Bourne, Arthur G. "Exploitation of the Small Whales in the North Atlantic." Oryx: The Journal of the Fauna Preservation Society 8, no. 3 (1965): 185-93.

Braitman, Laurel. "Animal Pharm." In Animal Madness: Inside Their Minds, Second Edition., 194-228. New York: Simon \& Schuster Paperbacks, 2015.

Branning, Timothy. "Whales: He Brought 'Em Back Alive." Independent PressTelegram. August 24, 1974.

Brown, David H. "Behavior of a Captive Pacific Pilot Whale." Journal of Mammalogy 41, no. 3 (August 1960): 342-49. 
— "Further Observations on the Pilot Whale in Captivity." Zoologica: Scientific Contributions of the New York Zoological Society 47, no. 1 (May 9, 1962).

Brown, David H., David K. Caldwell, and Melba C. Caldwell. "Observations on the Behavior of Wild and Captive False Killer Whales, with Notes on Associated Behavior of Other Genera of Captive Delphinids." Los Angeles County Museum Contributions in Science 95 (April 4, 1966).

Brown, David H., Rankin W. McIntyre, C. A. Delli Quadri, and Robert J. Schroeder. "Health Problems of Captive Dolphins and Seals." Journal of the American Veterinary Medical Association 137, no. 9 (November 1, 1960): 534-38.

"Bubbles Gets Whale of a Tummy Ache, Coughs Up Life Ring." Palos Verdes News. July 11, 1957.

"Bubbles, Pilot Whale at SeaWorld San Diego, Dies." Orange County Register, June 11, 2016. https://www.ocregister.com/2016/06/11/bubbles-pilot-whale-at-seaworldsan-diego-dies/.

"Bubbles Wasn't Lovesick, She Just Needed a Dose of Bicarb." San Pedro News Pilot, July 6, 1957. Kenneth S. Norris Papers UA 66 Box 59. University of California Santa Cruz Special Collections and Archives.

Buechl, Helen. “Animal Tranquilizers." The Science News-Letter 74, no. 7 (August 16, 1958): 106-7.

Burnett, D. Graham. The Sounding of the Whale: Science and Cetaceans in the Twentieth Century. The University of Chicago Press, 2013.

Busch, Briton Cooper. The War Against the Seals: A History of the North American Seal Fishery. Montreal: McGill-Queen's University Press, 1985.

Butler, M. Blake. "'Fishing on Porpoise:' The Origins, Struggles, and Successes of the Tuna-Porpoise Controversy." Master's thesis, University of Victoria, 2017.

Caldwell, David K., and David H. Brown. "Tooth Wear as a Correlate of Described Feeding Behavior by the Killer Whale, with Notes on a Captive Specimen." Bulletin of the Southern California Academy of Sciences 63, no. 3 (1964): 12840.

Caldwell, David K., and Melba C. Caldwell. "Epimeletic (Care-Giving) Behavior in Cetacea." In Whales, Dolphins, and Porpoises, edited by Kenneth S. Norris. Berkeley: University of California Press, 1966.

Caldwell, Melba C., David H. Brown, and David K. Caldwell. "Intergeneric Behavior by a Captive Pacific Pilot Whale." Los Angeles County Museum Contributions in Science 70 (October 4, 1963).

Caldwell, Melba C., and David K. Caldwell. "Behavior of Marine Mammals." In Mammals of the Sea: Biology and Medicine, edited by Sam H. Ridgway, 419-65. Springfield, Illinois: Charles C Thomas, 1972.

_. "Behavior of Marine Mammals." In Mammals of the Sea: Biology and Medicine, edited by Sam H. Ridgway, 419-65. Springfield, Ilinois: Charles C. Thomas, 1972.

"Camera at Marineland Records Delivery of the First Porpoise Ever Born in Captivity." Life Magazine, February 26, 1940.

Campeau, Bill. "Lights, Camera, Action... Bubbles Stars on Television." Palos Verdes News Anniversary Edition. May 27, 1965. 
Cate, T.W. California: World in a Week. United Air Lines, 1964.

Chace, Lynwood. "Blackfish Bonanza." Natural History, January 1954.

Chapin, Henry. The Remarkable Dolphin \& What Makes Him So. New York: Young Scott Books, 1962.

Chase, Kip. "Bubbles Still Sad; He Whale Ain't He," undated. Kenneth S. Norris Papers UA 66 Box 59. University of California Santa Cruz Special Collections and Archives.

Clark, A. Howard. "The Blackfish and Porpoise Fisheries." In The Fisheries and Fishery Industries of the United States, edited by George Brown Goode, 2:295-310. History and Methods of the Fisheries 4. Washington, DC: Government Printing Office, 1887.

Clark, James B. Flipper. Metro-Goldwyn-Mayer, 1963.

Colby, Jason. "Changes in Black and White: Killer Whale Bodies and the New Pacific Northwest." In The Historical Animal, edited by Susan Nance. Syracuse, New York: Syracuse University Press, 2015. . "The Whale and the Region: Orca Capture and Environmentalism in the New Pacific Northwest." Journal of the Canadian Historical Association 24, no. 2 (2013): 425-54.

Coleman, Jon T. Vicious: Wolves and Men in America. New Haven: Yale University Press, 2004.

Cornell, Lanny H., and Edward D. Asper. "A Census of Captive Marine Mammals in North America." International Zoo Yearbook 18, no. 1 (1978): 220-24.

Cousteau, Jacques-Yves. The Silent World. Columbia Pictures, 1956.

Cowperthwaite, Gabriela. Blackfish. Magnolia Pictures, 2013.

"Curator." Palos Verdes News. February 11, 1954.

Dahlheim, Marilyn E., Alisa Schulman-Janiger, Nancy Black, Richard Ternullo, Dave Ellifrit, and Kenneth C. Balcomb III. "Eastern Temperate North Pacific Offshore Killer Whales (Orcinus Orca): Occurrence, Movements, and Insights into Feeding Ecology." Marine Mammal Science 24, no. 3 (July 2008): 719-29.

Davis, Mike. "How Eden Lost Its Garden." In Ecology of Fear: Los Angeles and the Imagination of Disaster, 2nd ed., 57-91. New York: Vintage Books, 1999.

Davis, Susan G. Spectacular Nature: Corporate Culture and the Sea World Experience. Berkeley: University of California Press, 1997.

Depew, Joseph. "Back to Marineland." The Beverly Hillbillies. CBS, November 4, 1964.

"Destruction of the Seals." Evening Star. October 20, 1897.

Deutsch, Ronald M. "World's Largest Fishbowl." Lincoln and Mercury Times, April 1956.

Dewhurst, Henry William. The Natural History of the Order Cetacea, and the Oceanic Inhabitants of the Arctic Regions. London: Henry William Dewhurst, 1834.

Dillin, John W. "Flippy the Educated Porpoise." Natural History, April 1952.

"Dolphin Meat." The Brooklyn Daily Eagle. November 16, 1884.

Dolphins and the Tuna Industry. Washington, DC: National Academy Press, 1992.

Dunlevy, Bill. "Wanda the Whale Takes Residence at Marineland." Independent. November 20, 1961. 
Eckert, Allan W. In Search of a Whale. Marlin Perkins' Wild Kingdom. New York: Doubleday \& Company, 1970.

Elder, Pliny the. "Book IX: The Natural History of the Fishes." In The Natural History of Pliny, translated by John Bostock and H. T. Riley, 2:358-477. London: Henry G. Bohn, 1855.

Eschricht, D. F. "On the Species of the Genus Orca Inhabiting the Northern Seas." In Recent Memoirs on the Cetacea by Professors Eschricht, Reinhardt and Lilljeborg, edited by William Henry Flower, 153-88. London: Robert Hardwicke, 1866.

Essapian, Frank S. "The Birth and Growth of a Porpoise." Natural History, 1953.

"Fish That Knows No Fear." Sausalito News. May 17, 1919.

"Florida to Marineland Journey for Dolphin." Palos Verdes News. April 7, 1960.

Ford, John K. B. "Killer Whale (Orcinus Orca)." In Encyclopedia of Marine Mammals, edited by William F. Perrin, Bernd Würsig, and J. G. M. Thewissen, 2nd ed., 650-57. New York: Academic Press, 2009.

Ford, John K. B., Graeme M. Ellis, Craig O. Matkin, Michael H. Wetklo, Lance G. Barrett-Lennard, and Ruth E. Withler. "Shark Predation and Tooth Wear in a Population of Northeastern Pacific Killer Whales.” Aquatic Biology 11 (2011): 213-24.

Fraser, A. F. "Behavior Disorders in Domestic Animals." In Abnormal Behavior in Animals, edited by M. W. Fox, 179-87. Philadelphia: W. B. Saunders Company, 1968.

Geivet, Bob. "Killer Whale Netted in Newport Harbor." Independent Press-Telegram. November 19, 1961.

Geraci, Joseph R., and Kurt E. Gerstmann. "Relationship of Dietary Histamine to Gastric Ulcers in the Dolphin." Journal of the American Veterinary Medical Association 149, no. 7 (October 1, 1966): 884-90.

“Gigantic Plant to Pump Over Million Gallons of Water." Palos Verdes News, August 12, 1954.

Gilmore, Raymond M. Bubbles and Other Pilot-Whales. Del Mar, California: Barley Brae Printers, 1962.

—. "The Whaling Industry: Whales, Dolphins, and Porpoises." In Marine Products of Commerce: Their Acquisition, Handling, Biological Aspects and Science and Technology of Their Preparation and Preservation, by Donald K. Tressler and James McW. Lemon, 680-715, 2nd ed. New York: Reinhold Publishing Corporation, 1951.

Gosliner, Michael L. "The Tuna-Dolphin Controversy.” In Conservation and Management of Marine Mammals, edited by John R. Twiss and Randall R.

Reeves. Washington, DC: Smithsonian Institution Press, 1999.

Gray, William B. Porpoise Tales. New York: A.S. Barnes and Company, 1964.

Griffin, Edward I. "Making Friends With a Killer Whale." National Geographic, March 1966.

Griffin, Ted. Namu: Quest for the Killer Whale. Seattle, Washington: Gryphon West Publishers, 1982. 
Gunter, Gordon. "Contributions to the Natural History of the Bottlenose Dolphin,

Tursiops Truncatus (Montague), on the Texas Coast, with Particular Reference to Food Habits." Journal of Mammalogy 23, no. 3 (August 1942): 267-76.

. "Mammals of the Gulf of Mexico." In Gulf of Mexico: Its Origin, Waters, and

Marine Life, Fishery Bulletin of the Fish and Wildlife Service:543-51. Fishery

Bulletin 89. Washington, DC: United States Government Printing Office, 1954.

Hackett, Don. The Story of Bubbles the Whale. New York: The Saalfield Publishing Company, 1963.

. The Story of Bubbles the Whale. 2nd ed. Akron, Ohio: The Saalfield Publishing Company, 1967.

Hamilton, Robert. The Naturalist's Library: Mammalia, Whales, \&tc. Edited by William Jardine. Vol. 26. Edinburgh: W. H. Lizars, 1837.

Heffler, Robin. "Pregnant Corky Takes Lessons in Motherhood." Los Angeles Times.

September 3, 1981.

"High Tide." Coronado Journal. August 25, 1955.

Hill, Ralph Nading. Window in the Sea. New York: Rineheart \& Company Inc., 1956.

Hillinger, Charles. "Marineland: Science Boon." Los Angeles Times. January 24, 1965.

Hohn, Aleta A. "Age Estimation." In Encyclopedia of Marine Mammals, edited by

William F. Perrin, Bernd Würsig, and J. G. M. Thewissen, 2nd ed., 11-17. New

York: Academic Press, 2009.

Hoyt, Erich. Orca: The Whale Called Killer. Fourth. Firefly Books Ltd., 1990.

Hugo, Kristin. "Orca Shows and Breeding Banned in California." National Geographic,

September 14, 2016. https://news.nationalgeographic.com/2016/09/california-

bans-SeaWorld-orca-breeding-entertainment/.

"Iceland: Killing the Killers." Time, October 4, 1954.

Jacobs, Jake. Marineland Diver. New York: Dodd, Mead \& Company, 1960.

Jacobs, Jr., Lou. Cyra-Nose the Sea Elephant. Chicago: Children's Press, 1973.

- Duncan the Dolphin. Chicago: Follett Publishing Company, 1966.

. Four Walruses From Arctic to Oceanarium. New York: Young Scott Books, 1968.

. Wonders of an Oceanarium: The Story of Marine Life in Captivity. San Carlos, California: Golden Gate Junior Books, 1965.

Jefferson, Thomas A., Marc A. Webber, Robert L. Pitman, and Brett Jarrett. Marine Mammals of the World: A Comprehensive Guide to Their Identification. New York: Academic Press, 2008.

Kakolewski, J. W. "Psychopharmacology: Clinical and Experimental Aspects." In Abnormal Behavior in Animals, edited by M. W. Fox, 523-43. Philadelphia: W. B. Saunders Company, 1968.

Kellogg, Remington. "Whales, Giants of the Sea." National Geographic, January 1940.

"Kenneth S. Norris Field Notes," n.d. Kenneth S. Norris Papers UA 66. University of

California Santa Cruz Special Collections and Archives.

"Killer Whale Dies in Tank." The Register. November 20, 1961.

"Killer Whale in New Home at Marineland." Los Angeles Times. November 20, 1961.

“Killer Whale Succumbs.” Palos Verdes News. November 22, 1961. 
"Killer Whales Destroyed: VP-7 Accomplishes Special Task." Naval Aviation News, December 1956.

"Killers in Monterey Bay." Daily Alta California. August 6, 1871.

Kimura, Seiji, and Takahisa Nemoto. "Note on a Minke Whale Kept Alive in Aquarium." Scientific Reports of the Whales Research Institute 11 (1956): 181-89.

Kristjansson, F. K. "A Note on the Use of Chlorpromazine in the Treatment of Extreme Nervousness and Savageness in Farrowing Sows." Canadian Journal of Comparative Medicine and Veterinary Science 21, no. 11 (1957): 389-90.

Kritzler, Henry. "Observations on the Pilot Whale in Captivity." Journal of Mammalogy 33, no. 3 (August 1952): 321-34.

La Gorce, Gilbert Grosvenor, and Luis Marden. "Marineland, Florida's Giant Fish Bowl." National Geographic, November 1952.

Landauer, Lyndall B. "Charles M. Scammon: From Seaman to Civilized Whaler to Naturalist." California History 61, no. 1 (1982): 46-57.

Lehman, Bob. "The Munsters." Marineland Carnival. CBS, April 18, 1965.

Leiren-Young, Mark. The Killer Whale Who Changed the World. Vancouver, Canada: Greystone Books, 2016.

Lewkowitsch, J. "Dolphin Oil, Blackfish Oil.” In Chemical Technology and Analysis of Oils, Fats and Waxes, 5th ed. Vol. 2. London: MacMillan and Co., 1914.

Lilly, John C. Man and Dolphin: Adventures on a New Scientific Frontier. Garden City, New York: Doubleday \& Company, Inc., 1961.

Linneaus, Carl. Systema Naturae per Regna Tria Naturae: Secundum Clases, Ordines, Genera, Species, Cum Characteribus, Differentiis, Synonymis, Locis. 10th ed. Vol. 1. Stockholm: Laurentii Salvii, 1759.

"Mabel the Whale Gets Relief from Sunburn in Giant Marineland Pool." Los Angeles Times, March 7, 1957.

"Make Porpoise History Flying from Florida." Palos Verdes News. October 7, 1954.

"Makes Catching Porpoises Kinder." Palos Verdes News. August 18, 1955.

"Mammal Curator Talks to Science Clubbers." Palos Verdes News. April 22, 1965. Marine Studios Promotional Booklet. St. Augustine, Florida: The Record Press, 1946. "Marineland Begins Quest for “Alice." Palos Verdes News. May 13, 1954.

"Marineland Gets New Baby Whale." Palos Verdes News. July 3, 1958.

"Marineland Invents Device for Nabbing Fast Dolphins." Valley News. August 18, 1955.

"Marineland of Pacific Opens New Sea Arena." Palos Verdes News. July 10, 1958.

Marineland of the Pacific. "Information Sheet and Schedule of Events," 1959.

Marineland of the Pacific: A Coloring Book. New York: The Saalfield Publishing Company, 1962.

"Marineland of the Pacific Full-Page Advertisement." Palos Verdes News. November 4, 1954.

Marineland of the Pacific Information Booklet. Palos Verdes, California: Oceanarium, Inc., 1964.

Marineland of the Pacific Miniature Picture Booklet. New York: Dexter Press, 1969.

"“Marineland of the Pacific': Palos Verdes Site of Multimillion Dollar Project." Palos Verdes News, May 14, 1953. 
"Marineland of the Pacific Promotional Brochure." Oceanarium, Inc., 1959. Author's personal collection.

"Marineland of the Pacific Visitor Booklet." Oceanarium, Inc., 1964. Author's personal collection.

“"Marineland': Palos Verdes, California." Progressive Architecture, October 1955. Marton, Andrew. "Killer Whale." Sea Hunt, March 22, 1958.

May, Elaine Tyler. Homeward Bound: American Families in the Cold War Era. New York: Basic Books, 1988.

McBride, Arthur F. "Meet Mister Porpoise.” Natural History 45, no. 1 (January 1940). McBride, Arthur F., and D.O. Hebb. "Behavior of the Captive Bottle-Nose Dolphin, Tursiops Truncatus." Journal of Comparative and Physiological Psychology 41 (1948).

McBride, Arthur F., and Henry Kritzler. "Observations on Pregnancy, Parturition, and Postnatal Behavior in the Bottlenose Dolphin." Journal of Mammalogy 32, no. 3 (August 1951): 251-66.

McFadden \& Eddy Associates. "Facts About Marineland of the Pacific Press Release." Marineland of the Pacific, undated.

Meier, Don. "In Search of a Porpoise." Mutual of Omaha's Wild Kingdom. NBC, October 30, 1966.

Melville, Herman. Moby Dick. Vol. 1. 2 vols. London: Constable and Company, 1922.

"Misfortune Dogged Capt. Scott's Steps: Antarctic Hero's Diary Shows an Indomitable Will Fighting Great Odds from the Start." New York Times. June 24, 1913.

Mitchell, Edward. "Porpoise, Dolphin and Small Whale Fisheries of the World: Status and Problems." Monograph. Morges, Switzerland: International Union for Conservation of Nature and Natural Resources, 1975.

Mitman, Gregg. Reel Nature: America's Romance with Wildlife on Film. Cambridge, Mass.: Harvard University Press, 1999.

Morejohn, G. Victor. "The Natural History of Dall's Porpoise in the North Pacific Ocean." In Behavior of Marine Animals: Current Perspectives in Research Volume 3: Cetaceans, edited by Howard E. Winn and Bori L. Olla, 3:45-83. New York: Plenum Press, 1979.

Morin, Phillip A., Richard G. LeDuc, Kelly M. Robertson, Nicole M. Hedrick, William F. Perrin, Michael Etnier, Paul Wade, and Barbara L. Taylor. "Genetic Analysis of Killer Whale (Orcinus Orca) Historical Bone and Tooth Samples to Identify Western U.S. Ecotypes." Marine Mammal Science 22, no. 4 (October 2006): 897909.

Mowbray, Louis L. "Certain Citizens of the Warm Sea." National Geographic, January 1922.

"My Pal Flipper." Life Magazine, June 7, 1963.

Newman, Murray. Life in a Fishbowl: Confessions of an Aquarium Director. Vancouver: Douglas and McIntyre, 1994.

Newman, Murray A., and Patrick L. McGreer. "A Killer Whale (Orcinus Orca) at Vancouver Aquarium." International Zoo Yearbook 6 (1966): 257-59.

"Newport Sailors Have a Whale of a Problem." Pasadena Independent. November 17, 1961. 
Norris, Charlotte B. “A Porpoise with a Purpose.” Natural History, January 1957.

Norris, Kenneth S. "Aggressive Behavior in Cetacea." In Aggression and Defense:

Neural Mechanisms and Social Patterns: Proceedings of Fifth Conference on

Brain Function, edited by Carmine D. Clemente and Donald B. Lindsley, 225-41.

UCLA Forum in Medical Sciences 7. University of California Press, 1967.

—_. "Collecting for the World's Largest Fishbowl." Natural History, March 1957.

. "Facts and Tales About Killer Whales." Pacific Discovery, February 1958.

— ed. "Round Table: Practical Problems." In Whales, Dolphins, and Porpoises. Berkeley: University of California Press, 1966.

."The Big One Got Away." Pacific Discovery, September 1958.

. The Porpoise Watcher: A Naturalist's Experiences with Porpoises and Whales. New York: W. W. Norton \& Company, 1974.

Norris, Kenneth S., and David H. Brown. "Observations of Captive and Wild Cetaceans." Journal of Mammalogy 37, no. 3 (August 1956): 311-26.

Norris, Kenneth S., and John H. Prescott. Observations on Pacific Cetaceans of Californian and Mexican Waters. Vol. 63. University of California Publications in Zoology 4. Berkeley: University of California Press, 1961.

O'Barry, Richard. Behind the Dolphin Smile. Chapel Hill, N.C.: Algonquin Books, 1988.

Olson, Paula A. "Pilot Whales: Globicephala Melas and G. Macrorhynchus."

Encyclopedia of Marine Mammals. New York: Academic Press, 2009.

Penn, Briony. The Real Thing: The Natural History of Ian McTaggart Cowan. Victoria, British Columbia: Rocky Mountain Books Ltd., 2015.

Ponting, Herbert. The Great White Silence. Gaumont British Distributors, 1924.

"Porpoise Psychoanalyzed as Penguin Roller Skates." Los Angeles Times. September 27, 1956.

"Porpoises May Get Ulcers in Brooding Over Boredom." Los Angeles Times. April 25, 1966.

Porter, Roy. Madness: A Brief History. New York: Oxford University Press, 2002.

"Press Release: SeaWorld Announces Last Generation of Orcas in Its Care." SeaWorld Entertainment, Inc., March 17, 2016. http://www.seaworldinvestors.com/newsreleases/news-release-details/2016/SeaWorld-Announces-Last-Generation-OfOrcas-In-Its-Care/default.aspx.

Price, E.O. Principles and Applications of Domestic Animal Behavior: An Introductory

Text. Cambridge, Mass.: C.A.B. International, 2008.

"Purpose on Porpoise." Santa Cruz Sentinel. May 4, 1941.

Radcliffe, Lewis. "Whales and Porpoises as Food." Economic Circular No. 38. Bureau of Fisheries. Washington, DC: Department of Commerce, November 6, 1918.

"Rare Whale Lassoed, Taken to Aquarium." Los Angeles Times. February 23, 1956.

Rathjen, W.F., and J.R. Sullivan. "West Indies Whaling." Sea Frontiers, June 1970.

Rawlings, Clarence. "Psychology Used in Teaching Whales." Madera Daily News Tribune. October 1, 1959.

"Ray Smith Resigns at Marineland." Palos Verdes News. January 26, 1956.

Reeves, Randall R., and James G. Mead. "Marine Mammals in Captivity." In Conservation and Management of Marine Mammals, edited by John R. Twiss and Randall R. Reeves. Washington, DC: Smithsonian Institution Press, 1999. 
Reeves, Randall R., Brent S. Stewart, Phillip J. Clapham, and James A. Powell. "Baleen Whales." In National Audubon Society Guide to Marine Mammals of the World, 184-87. New York: Alfred A. Knopf, 2002.

. "Common Bottlenose Dolphin." In National Audubon Society Guide to Marine

Mammals of the World, 358-61. New York: Alfred A. Knopf, 2002.

. "Cuvier's Beaked Whale." In National Audubon Society Guide to Marine

Mammals of the World, 254-57. New York: Alfred A. Knopf, 2002.

. "Killer Whale." In National Audubon Society Guide to Marine Mammals of the

World, 436-39. New York: Alfred A. Knopf, 2002.

. National Audubon Society Guide to Marine Mammals of the World. New York:

Alfred A. Knopf, 2002.

. "Oceanic Dolphins." In National Audubon Society Guide to Marine Mammals of the World, 326-31. New York: Alfred A. Knopf, 2002.

. "Short-Finned Pilot Whale." In National Audubon Society Guide to Marine

Mammals of the World, 444-47. New York: Alfred A. Knopf, 2002.

. "Sperm Whales." In National Audubon Society Guide to Marine Mammals of the

World, 238-39. New York: Alfred A. Knopf, 2002.

Reti, Irene H., and Randall Jarrell. Kenneth S. Norris: Naturalist, Cetologist and

Conservationist, 1924-1998: An Oral History Biography. Berkeley: University of

California Press, 1999.

Ridgway, Sam, and Kurt Benirschke. "Breeding Dolphins; Present Status, Suggestions for the Future." U.S. Marine Mammal Commission. Washington, DC: Zoological Society of San Diego, November 1977.

Ridgway, Sam H. The Dolphin Doctor: A Pioneering Veterinarian Remembers the Extraordinary Dolphin That Inspired His Career. Dublin, New Hampshire: Yankee Books, 1987.

Sackman, Douglas C. "A Garden of Worldly Delights.” In Land of Sunshine: An Environmental History of Metropolitan Los Angeles, edited by William Deverell and Greg Hise, 245-66. Pittsburgh, Pennsylvania: University of Pittsburgh Press, 2005.

Samuels, Amy, and Peter L. Tyack. "Flukeprints: A History of Studying Cetacean Societies." In Cetacean Societies: Field Studies of Dolphins and Whales, edited by Janet Mann, Richard C. Connor, Peter L. Tyack, and Hal Whitehead, 9-44. Chicago: University of Chicago Press, 2000.

Scammon, Charles M. The Marine Mammals of the North-Western Coast of North America. San Francisco: John H. Carmany and Company, 1874.

Scammon, Charles M., and Edward D. Cope. "On the Cetaceans of the Western Coast of North America." Proceedings of the Academy of Natural Sciences of Philadelphia 21 (1869): 13-63.

“Scientific Events." Science 88, no. 2272 (July 15, 1938): 50.

Scott, Robert Falcon. Scott's Last Expedition. Vol. 1. 2 vols. New York: Dodd, Mead \& Company, 1913.

Scott, Vernon. "The Hollywood Scene.” Eureka Humboldt Standard. March 6, 1962.

"Sea Tragedy on Films: Capt. Scott's Companion Gets a Combat of Whales and Seal in Moving Pictures.” New York Times. June 27, 1912. 
"Season for Capturing Porpoises Begins Nov. 1." New York Herald. October 29, 1916. Sergeant, David E. "Age Determination in Odontocete Whales from Dentinal Growth Layers." Norsk Hvalfangst-Tidende 48, no. 6 (June 1959): 273-88.

."Whaling in Newfoundland and Labrador Waters." Norsk Hvalfangst-Tidende 42, no. 12 (1953): 687-95.

Shoemaker, Nancy. "Whale Meat in American History." Environmental History 10, no. 2 (April 2005): 269-94.

"Short-Finned Pilot Whale." NOAA Fisheries Species Directory. Washington, DC, n.d. https://www.fisheries.noaa.gov/species/short-finned-pilot-whale.

Siverts, Don. "Killer Whale!” Skin Diver Magazine, March 1962.

Slijper, E. J. Whales. Translated by A. J. Pomerans. New York: Basic Books, 1962.

Smith, Pete. "Marine Circus." Metro-Goldwyn-Mayer Short Story, April 1939.

Sommer, Volker, and Paul L. Vasey, eds. Homosexual Behaviour in Animals: An Evolutionary Perspective. New York: Cambridge University Press, 2006.

Southwell, Thomas. The Seals and Whales of the British Seas. London: Jarrold and Sons, 1881.

Sparks, George L. "Porpoise Products." In Bulletin of the United States Fish Commission, 4:415-16. Washington, DC: Government Printing Office, 1885.

"Spectators Thrill Daily to Antics." Palos Verdes News. November 8, 1956.

Spigel, Lynn. Make Room for TV: Television and the Family Ideal in Postwar America. Chicago: University Of Chicago Press, 1992.

Stecher, Paul G., ed. "Apomorphine Hydrochloride." The Merck Index of Chemicals and Drugs. Rahway, New Jersey: Merck \& Co., Inc., 1960.

- ed. "Prednisone." The Merck Index of Chemicals and Drugs. Rahway, New Jersey: Merck \& Co., Inc., 1960.

—, ed. "Promazine." The Merck Index of Chemicals and Drugs. Rahway, New Jersey: Merck \& Co., Inc., 1960.

Stevenson, Charles H. "Aquatic Products in Arts and Industries." Report of the Commissioner for the Year Ending June 30, 1902. Washington, DC: U.S.

Commission of Fish and Fisheries, 1904.

. "Utilization of the Skins of Aquatic Animals." Report of the Commissioner for the Year Ending June 30, 1902. Washington, DC: U.S. Commission of Fish and Fisheries, 1904.

Swann, Roy. "Pestilent Porpoise, Destructive Dolphin." The Corpus Christi CallerTimes. February 23, 1964.

Sweeney, J.C., and Sam H. Ridgway. "Common Diseases of Small Cetaceans." Journal of the American Veterinary Medical Association 167, no. 7 (October 1, 1975): 533-40.

“Terranea Resort Marineland Heritage Card.” Destination Hotels \& Resorts, n.d. Author's personal collection.

“Terror of the Antarctic--A Man-Killing Whale." The Times Dispatch. November 16, 1913.

“The Mammoth Moving of a Sea Mammal." Life Magazine, April 15, 1957.

The Natural History of Quadrupeds, and Cetaceous Animals. Vol. 2. 2 vols. Bungay, England: Brightly and Co., 1811. 
The Whale That Became a Star. Castle Films, 1960.

"They're Big, and So's Their Home." Palos Verdes News. August 16, 1956.

"To Marineland's Training Tank/Marineland of the Pacific to Open Saturday, August 28." Palos Verdes News. August 26, 1954.

Tone, Andrea. The Age of Anxiety: A History of America's Turbulent Affair with

Tranquilizers. New York: Basic Books, 2009.

Townsend, Charles H. "Endurance of the Porpoise in Captivity." Science 43, no. 111 (April 14, 1916): 534-35.

Townsend, Charles Haskins. "The Porpoise in Captivity.” Zoologica: Scientific Contributions of the New York Zoological Society 1, no. 16 (1914): 289-99.

Townsend, Dorothy. "Baby Needed Its Mother: Separation Blamed in Whale Death." Los Angeles Times. August 5, 1982, sec. OC.

_ . "Baby Whale, Mama Doing Fine So Far." Los Angeles Times. June 19, 1982. . "Baby Whale Stable; Public Gets First View." Los Angeles Times. June 27, 1982.

."Psychotic Bimbo Banished, Returned to Old Sea Haunts." Los Angeles Times, November 23, 1967.

. "Sad Saga of Bimbo, the Psychotic Whale." Los Angeles Times. February 7, 1965.

_ . "Stress Blamed in Baby Whale's Sudden Death." Los Angeles Times. August 5, 1982.

. "Whale Calf Fed Formula as Mother Spurns Milking." Los Angeles Times. June 23, 1982.

Townsend, Dorothy, and Jack Jones. "Marineland's Baby Killer Whale Dies.” Los Angeles Times. August 4, 1982.

"U.S. Bombing Killer Whales." New York Times. August 15, 1956.

"U.S. Troops in Iceland Receive Whale of a Job." New York Times. September 22, 1954.

Valentry, Duane. "Big Star All at Sea." Sea Frontiers, August 1969.

Van Nuys, Frank. Varmints and Victims: Predator Control in the American West.

Lawrence, Kansas: University Press of Kansas, 2015.

Walker, William A. "Review of the Live-Capture Fishery for Small Cetaceans Taken in Southern California Waters for Public Display, 1966-73." Journal of the Fisheries Research Board of Canada 32, no. 7 (1975): 1197-1211.

"Wanda Earmarked for Capture Today." The Register. November 18, 1961.

Washicko, Cynthia. "Iconic Statue of Marineland's Bubbles the Whale Will Return to Palos Verdes Peninsula." Daily Breeze. November 16, 2016. https://www.dailybreeze.com/2016/11/16/iconic-statue-of-marinelands-bubblesthe-whale-will-return-to-palos-verdes-peninsula/.

Watson, George E. "Bottlenose Porpoise Postcard." Golden West Color Card Company, 1960. Author's personal collection.

. "Marineland of the Pacific Dolphin Sign Postcard." Golden West Color Card Company, undated. Author's personal collection.

. "Marineland of the Pacific Entrance Sign Postcard." Golden West Color Card Company, undated. Author's personal collection. 
- Marineland of the Pacific Souvenir Picture Book. Long Beach, California: Golden West Color Card Company, 1966.

Weisel, Sandi. "Death of Corky's Bundle of Joy: Marineland Experts Still Ask Why." Los Angeles Times. August 27, 1982.

. "Great Expectations at Marineland." Los Angeles Times. February 12, 1982.

"Whale of an Autopsy Due." Palos Verdes News. March 15, 1956.

"Whales Are 'Airlifted' to Florida." Palos Verdes News. June 4, 1959.

"What Makes Salty Smile?" Los Angeles Times. December 2, 1962, sec. TW.

Whorf, Richard. "The Clampetts Go Fishing." The Beverly Hillbillies. CBS, February 26, 1964.

Wincer, Simon. Free Willy. Warner Bros. Family Entertainment, 1993.

Wood, Forest G. Marine Mammals and Man: The Navy's Porpoises and Sea Lions. Washington, DC: Robert B. Luce Inc., 1973.

Wyman, Jeffries. 'Description of a 'White Fish,' or 'White Whale,' (Beluga Borealiz Lesson.)." Boston Journal of Natural History 7, no. 1 (1863): 603-12.

Zeder, Melinda A. "Core Questions in Domestication Research." Proceedings of the National Academy of Sciences of the United States of America 112, no. 11 (March 17, 2015): 3191-3198. 